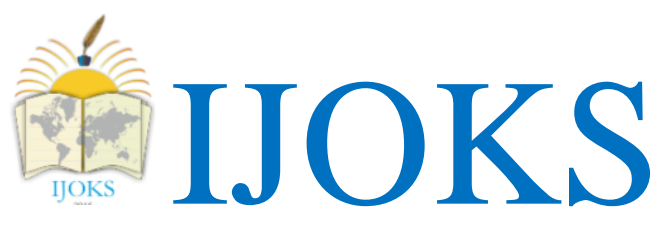

International Journal of Kurdish Studies

(ISSN:2149-2751)

5 (1), pp. $78-102$

http://www.ijoks.com

\title{
Kurdish Poetry from the perspective of the criteria of textuality, Kurdish poetry texts of Central Kurdish dialect as an example
}

Nawzad Waqas SAHID \& Rebwar Muhammed ISMAIL ${ }^{2}$

Received: Mar 18, 2018 Reviewed: Mar 22, 2018 Accepted: Apr 25, 2018

\begin{abstract}
This research is part of a doctoral thesis that aims to examine the nature and properties of text. The nature of text has been focused on by critics and theorists in various ways. It has also been interpreted differently within the framework of the philosophy of literature, literary criticism, and literary theory.

This article sheds light on the nature and value of text within the framework of theoretical and critical viewpoints. It highlights the general and specific criteria of textuality and claims that on the basis of those criteria a text receives its scientific identity. These measures are some general indicators for the existence of textuality and they cannot be imposed on one type of text.

This article conducts theoretical and critical analysis of Kurdish poetry in the Central Kurdish dialect using the concept of text and its textuality criteria. According to these criteria, which consider the general and specific principles of "text," Kurdish poetry texts of Central Kurdish dialect are bound to those criteria and receive identity of textuality. This is because the structure of Kurdish poetry texts in the Central Kurdish dialect has its own properties in terms of language, meaningfulness, identity, type of genre, and literary elements such as idea, imagination, emotion, and form. These aspects form the structure of the texts. Throughout the history of this literary school, these aspects have changed. This can be seen by analyzing and studying the texts with theoretical and critical criteria in mind.
\end{abstract}

Key words: Textuality, The nature of text, Structure of text, Intentionality, Cohesion, Situationality, Informativity, Intertextuality

\footnotetext{
1Professor, Department of Kurdish Language, college of education, Salahadin University-Erbil, Kurdistan Region-Iraq, E-mail: Nawzad.saeed@su.edu.krd,

${ }^{2}$ Correspondent Author: Lecturer, Department of Kurdish Language, college of education, Salahadin UniversityErbil, Kurdistan Region-Iraq E-mail: Rebwarafo2@gmail.com, ORCID NO: 0000-0001-7513-1513
} 
Kürt Şiiri metinselliği kriterleri açısından bakıldığında, örnek olarak Orta Kürt lehçesinin Kürt şiir metinleri

Öz

Bu araştırma, "Kürtçe Şiir, metinselliğin ölçütleri, Orta Kürt lehçesinin Kürt şiir metinleri bir örnek olarak ele alınmıştır." Metin niteliğini ve özelliklerini inceleyen doktora tezi kapsamındadır. metin - eleştirmenler ve teorisyenler tarafindan çeşitli şekillerde yoğunlaşmış, edebiyat felsefesi, edebi eleştiri ve edebi teori çerçevesinde farklı yorumlanmıştır. Bu araştırma, teorik ve eleştirel bakış açıları çerçevesinde metnin doğasına ve değerine sşık tutmaktadır. Metinselliğin genel ve özel kriterlerini vurgular ve bu kriterler temelinde bir metnin bilimsel kimliğini aldığını iddia eder. Bu ölçüler, metinselliğin varlığı için bazı genel özelliklerdir ve bir metin türüne uygulanamazlar.

Araştırma, metin kavramı ve metinsel kriterler ışığında, Orta Kürt lehçesinin Kürt şiir metinlerinin teorik ve eleştirel bir analizini vermektedir. "Metin" in genel ve özel ilkelerini dikkate alan ölçütlere göre, Kürtçe metinlerin Kürtçe metinleri, bu kriterlere bağlanır ve metinselliğin kimliğini alır. Bunun nedeni, Orta Kürt lehçesinin Kürt şiir metinlerinin yapısının, dil, anlamlılık, kimlik, tür türü ve düşünce, hayal gücü, duygu ve biçim gibi edebi unsurlar bakımından kendine özgü özellikleri olmasıdır. Bu yönler metinlerin yapısını oluşturur. Bu edebi okulun tarihi boyunca, metinleri teorik ve eleştirel ölçütlerle analiz ederek ve inceleyerek bilinebilecek olan yönler değişmiştir.

Anahtar Kelimeler: Metinbilim, Metin doğası, Metin Yapısı, Amaçlılık, Uyum, Durumsallık, Bilişsellik, Metinlerarasilik

\section{Recommended citation:}

Sahid, W.S. \&Ismail, M.I. (2019). Kurdish Poetry from the perspective of the criteria of textuality, Kurdish poetry texts of Central Kurdish dialect as an example. International Journal of Kurdish Studies5 (1), $78-102$ DOI: 10.21600/ ijoks. 516489

$$
\begin{aligned}
& \text { شيعرى كوردى، لِرورانكهى بِيْوهرهكانى دهقيّتى } \\
& \text { بهزمووزهى دهوقى شيعرى لهكرمانجى خواروودا } \\
& \text { ب..د. زهوزاد وقاص سعيد ---- م. ردِّبوارمحمداسماعيل }
\end{aligned}
$$

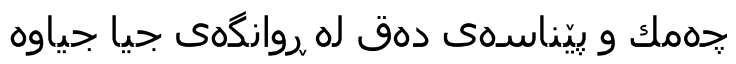

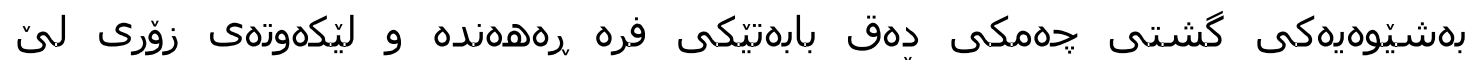

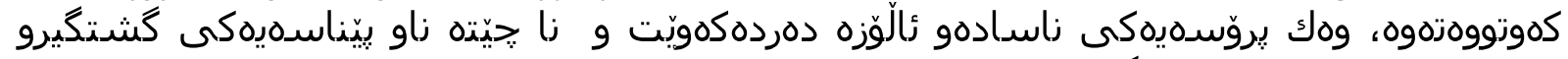

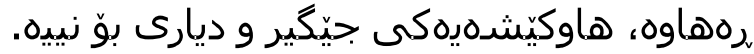

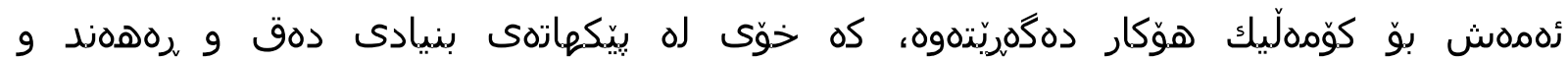

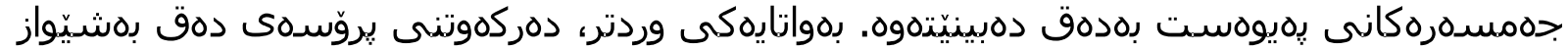

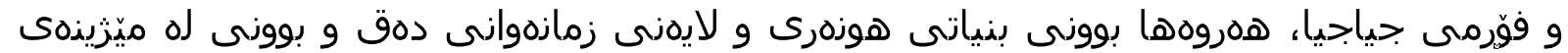

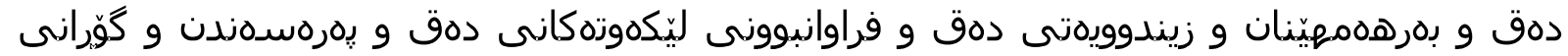

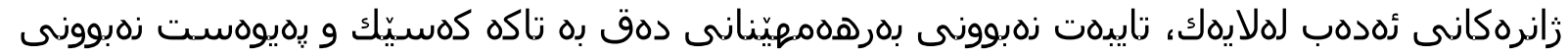

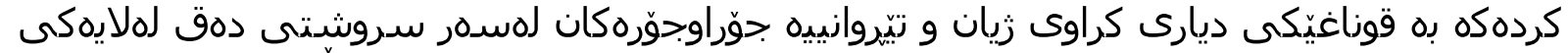

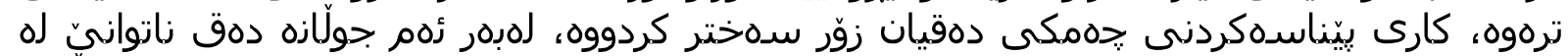

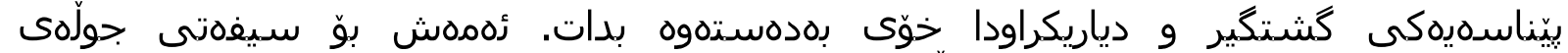

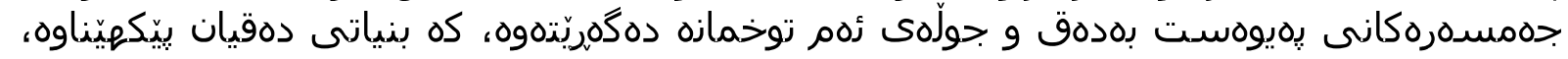

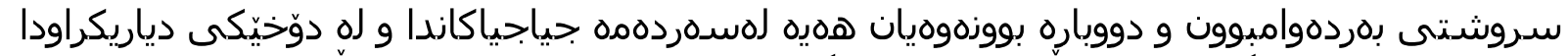

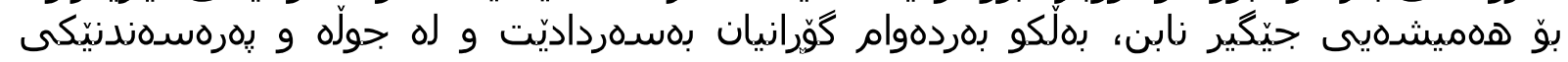




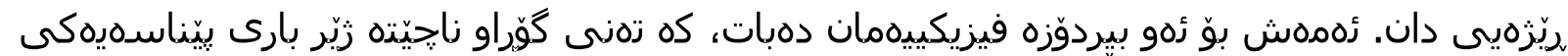

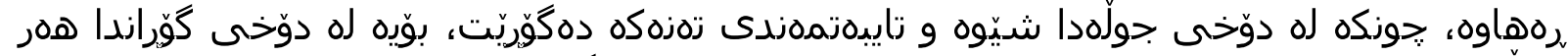

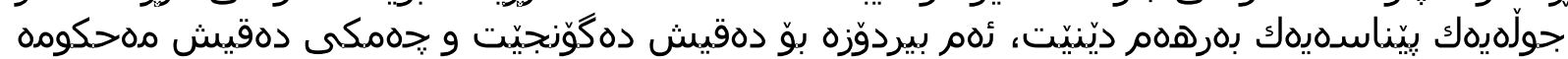
بههمان بذهماى فيزيكى.

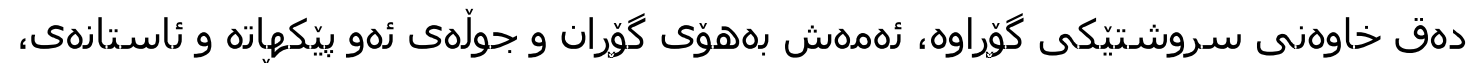

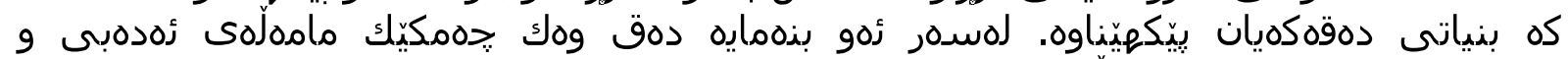

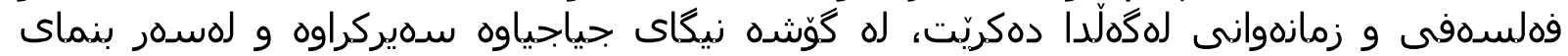

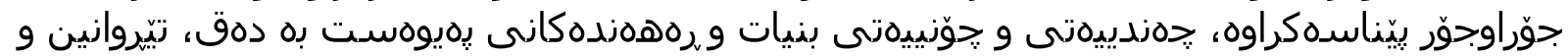

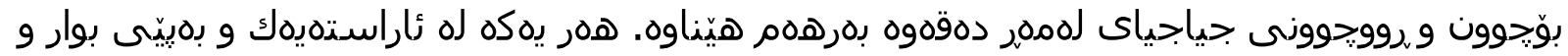

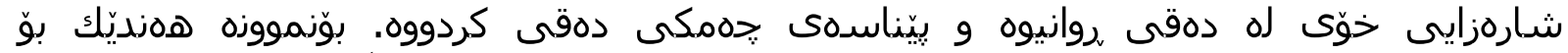

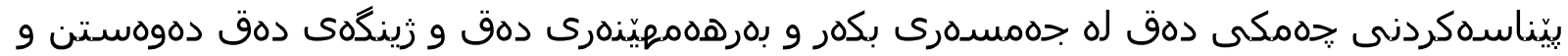

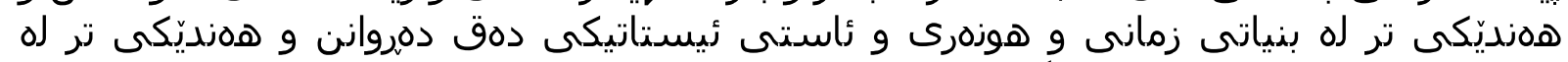

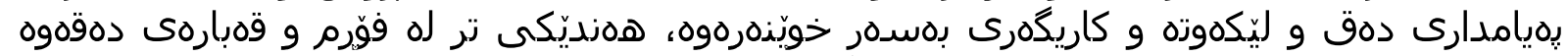

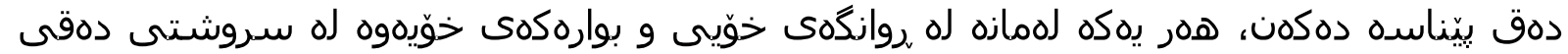

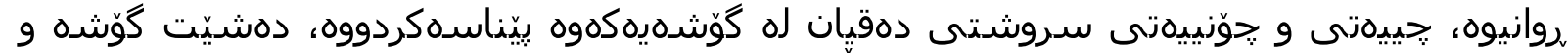

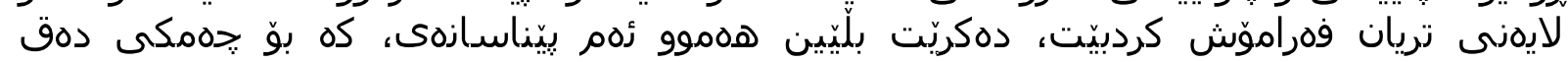

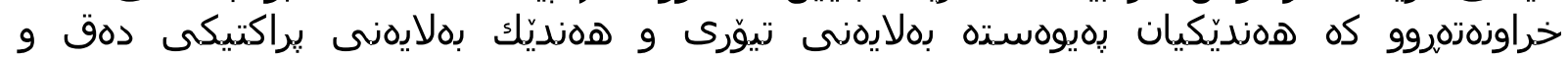

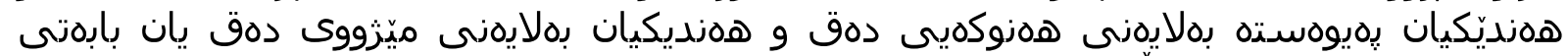

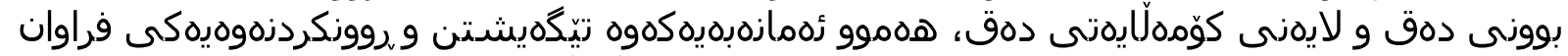

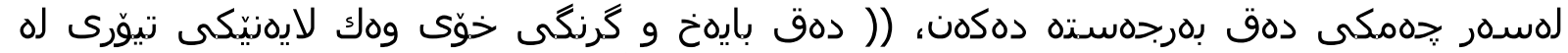

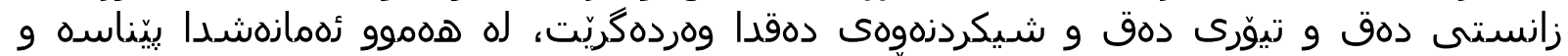

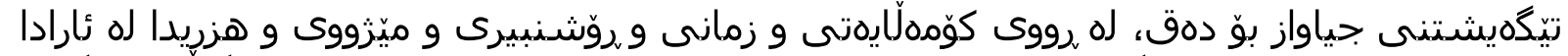

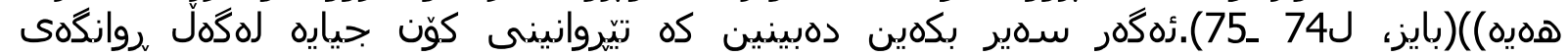

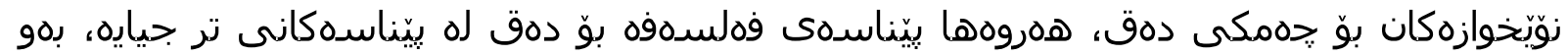

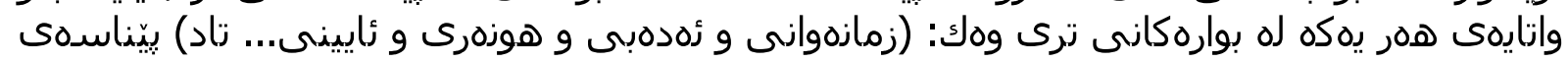

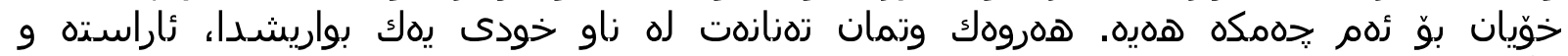

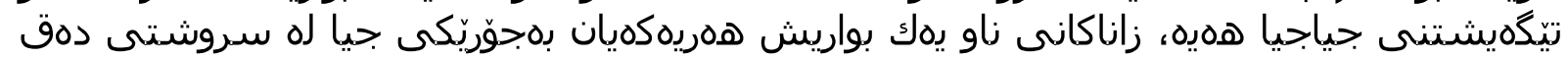

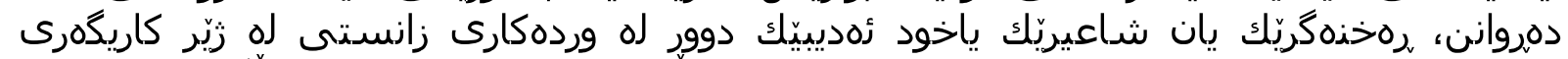

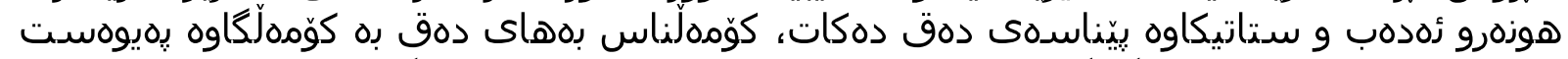

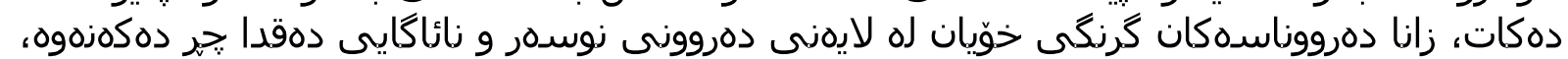

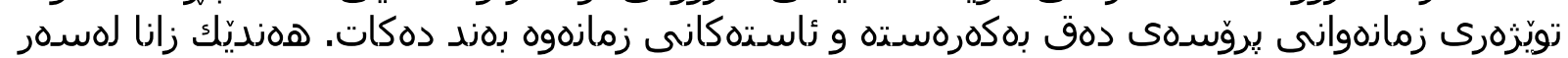

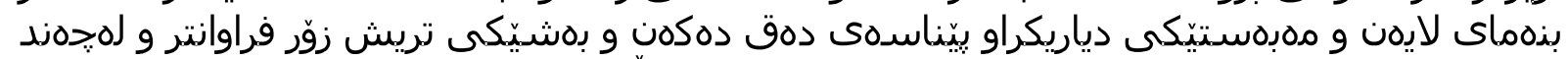

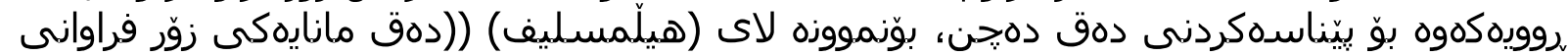

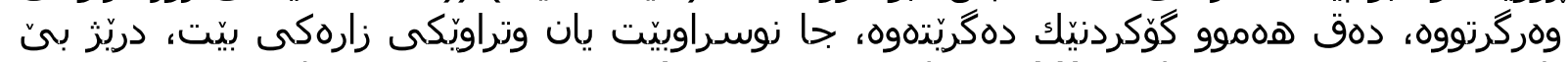

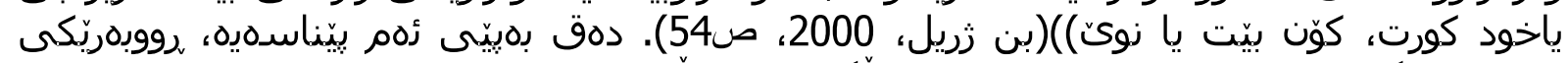

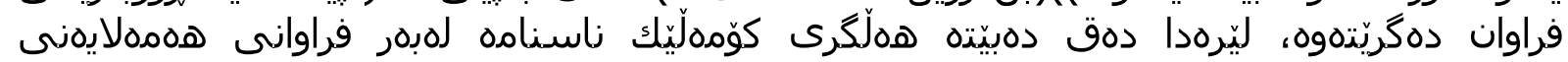

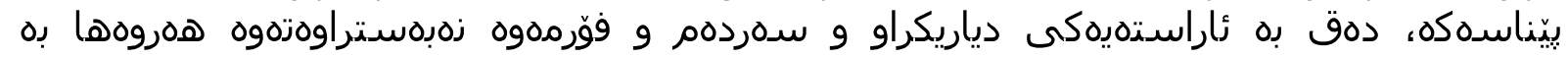

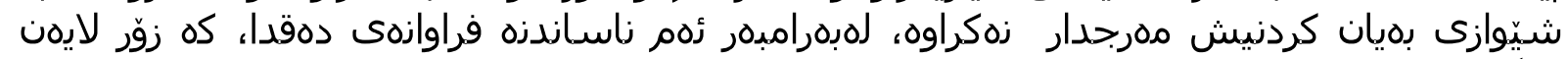

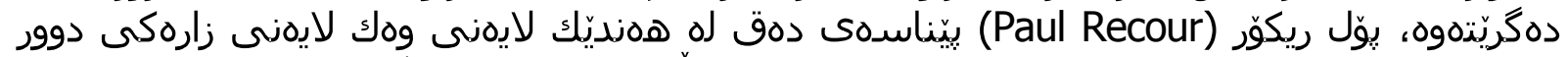

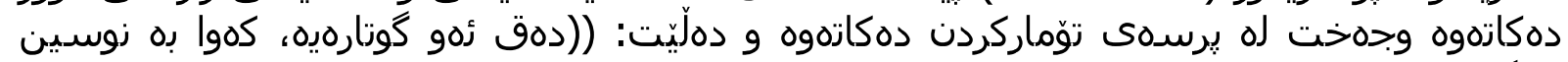

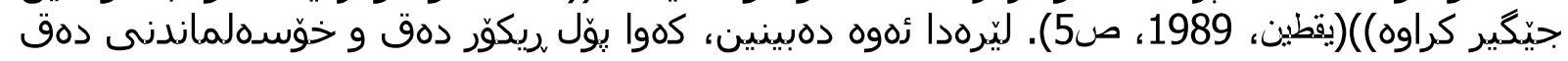

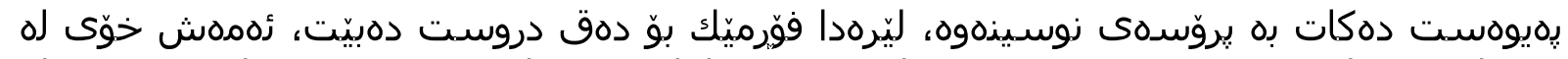

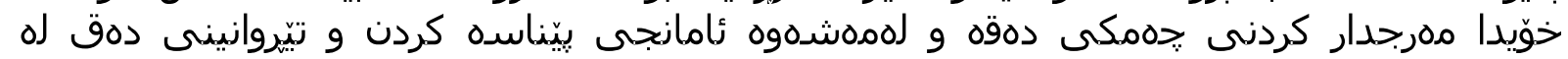

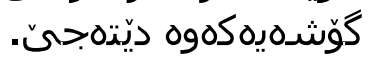

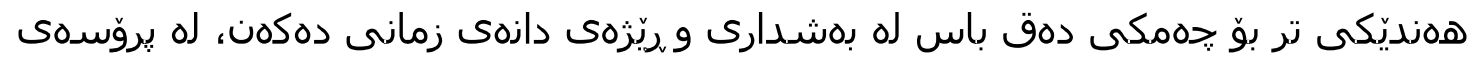

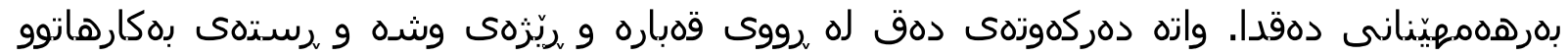




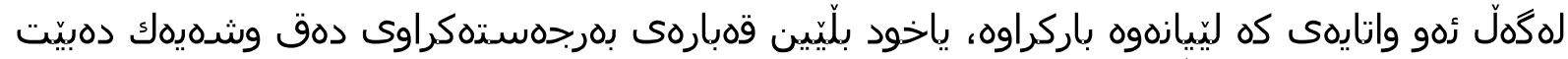

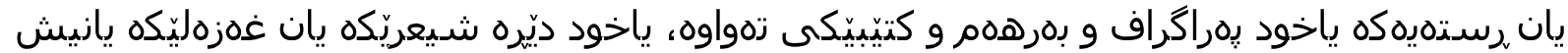

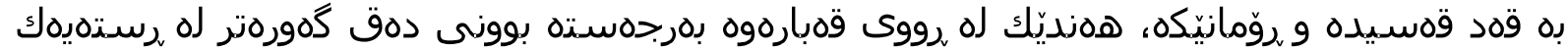

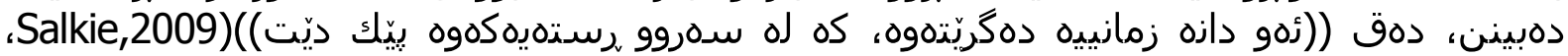

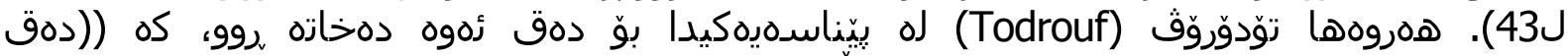

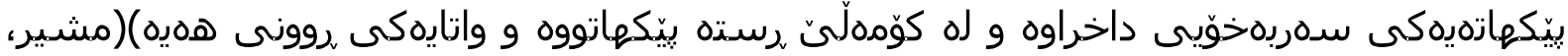

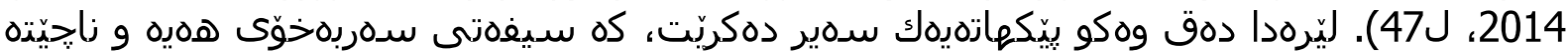

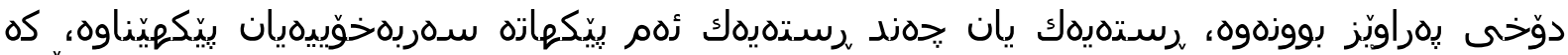

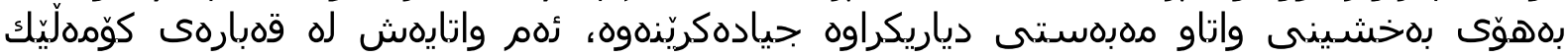

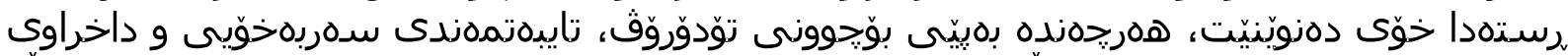

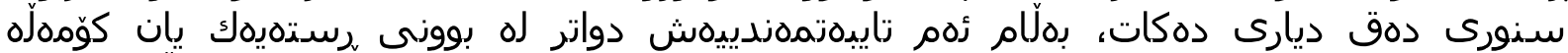

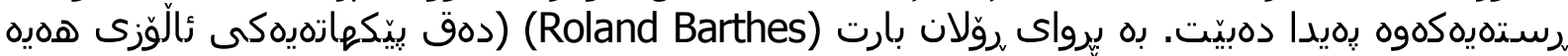

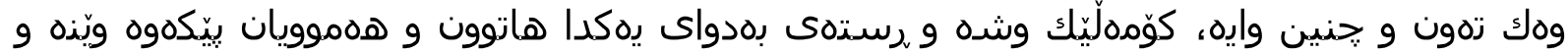

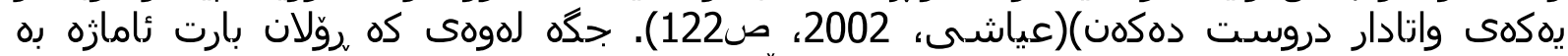

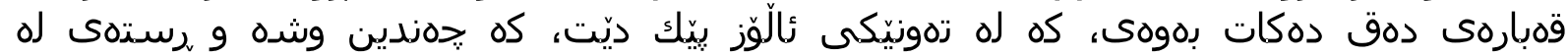

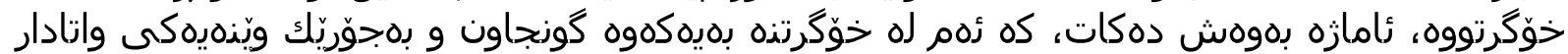

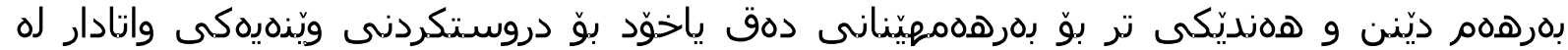

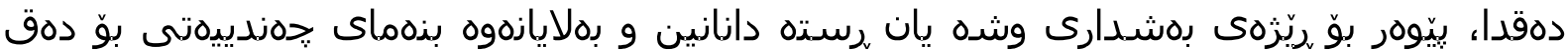

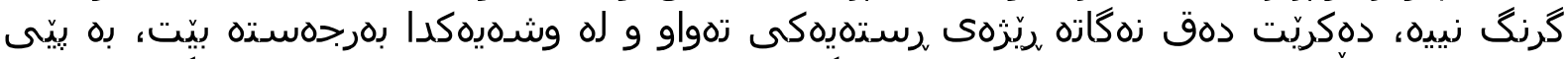

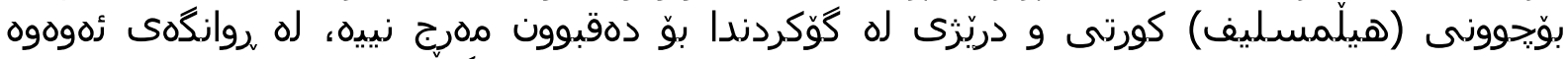

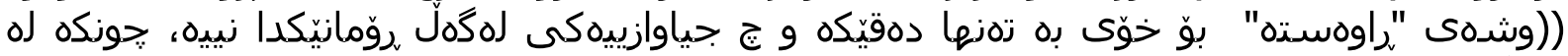

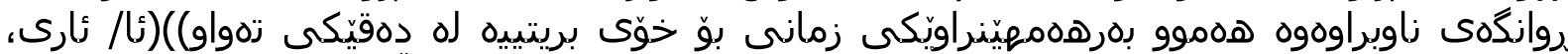

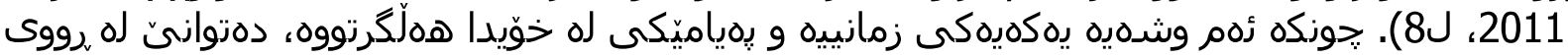

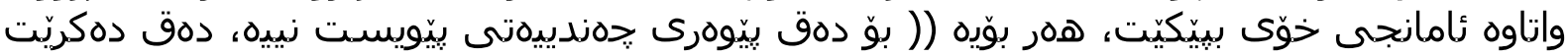

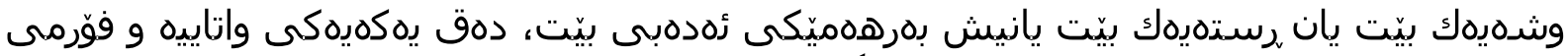

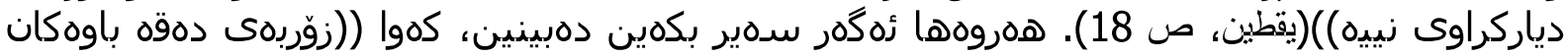

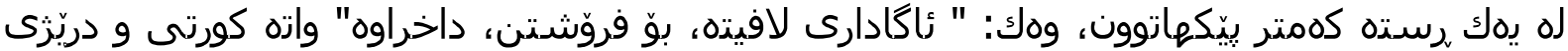

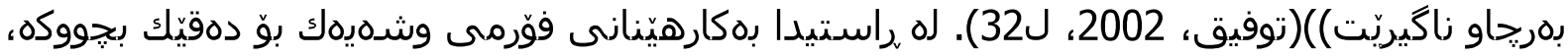

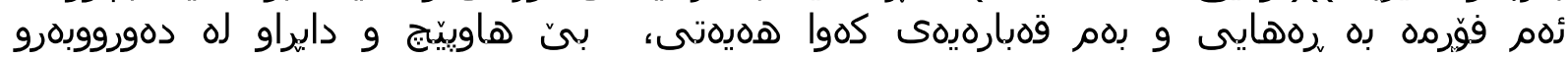

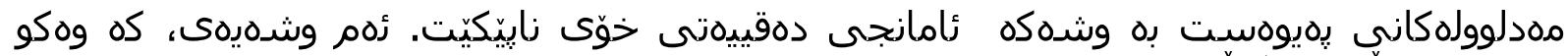

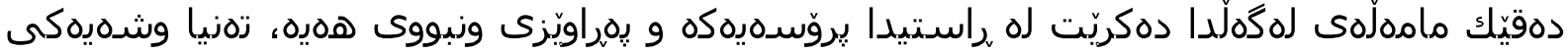

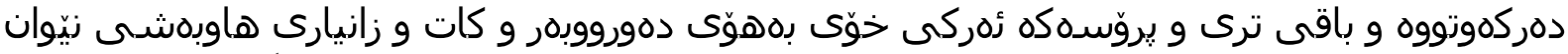

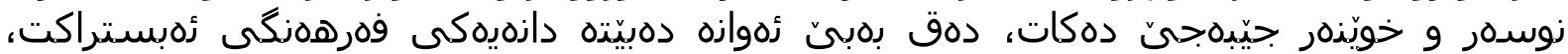

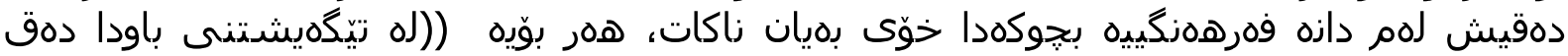

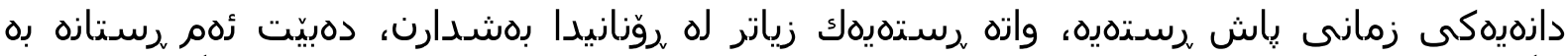

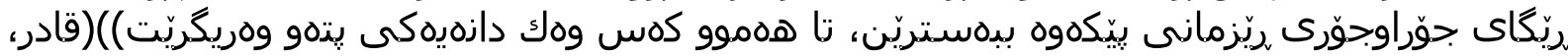

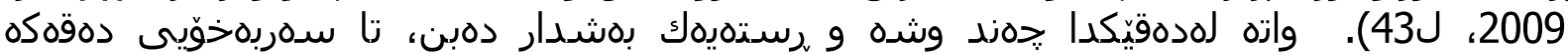

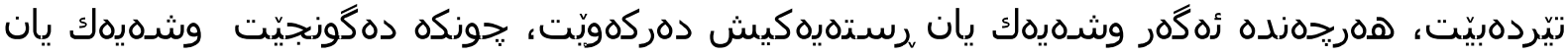

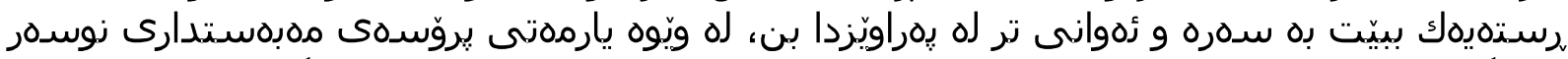

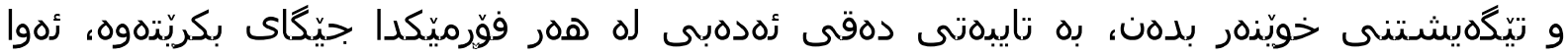

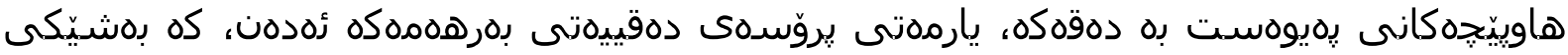

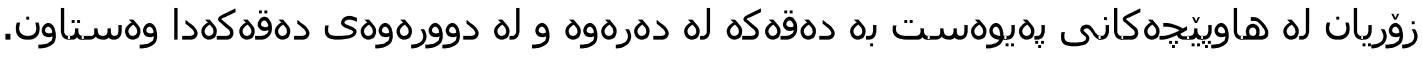

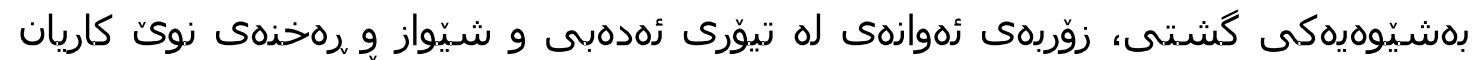

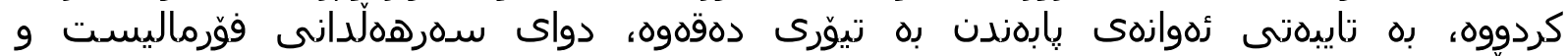

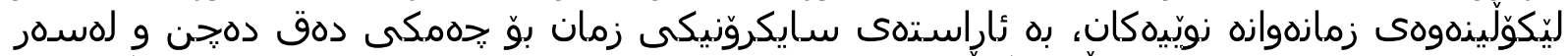

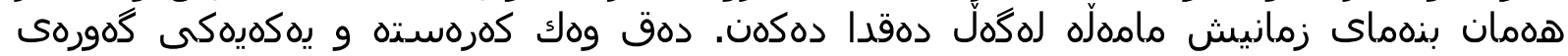

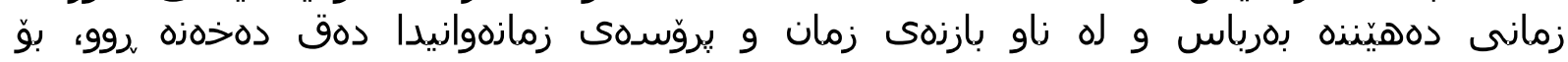




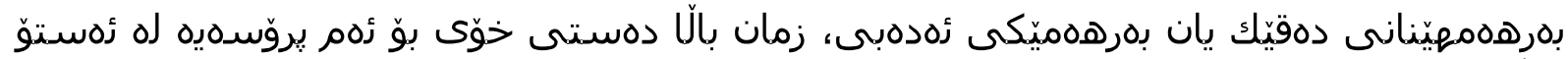

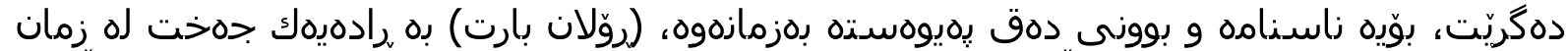

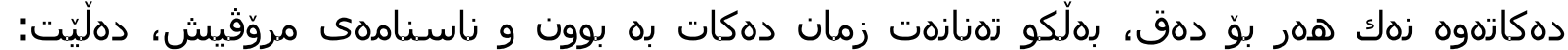

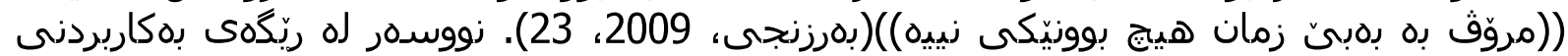

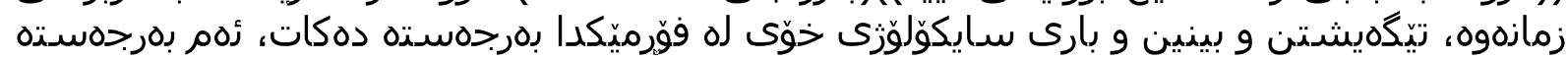

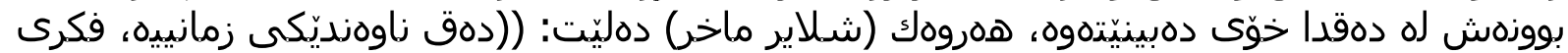

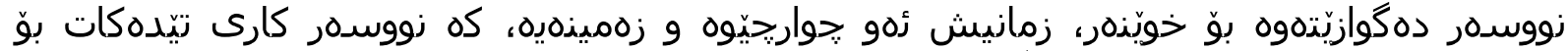

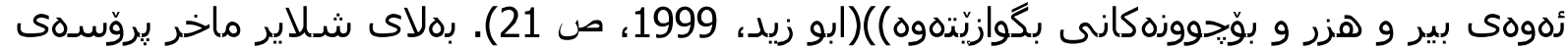

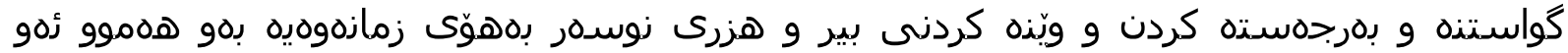

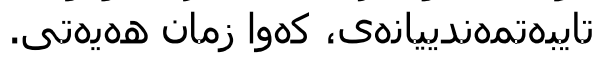
سروشتى دهق و بِيّوهركانى دهقيّتى

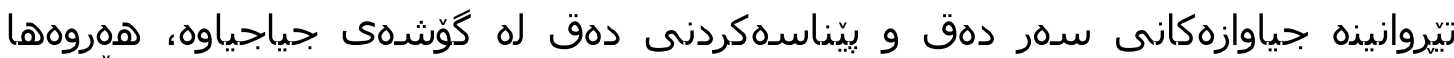

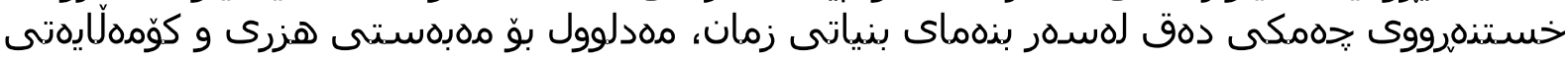

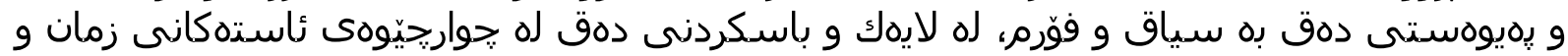

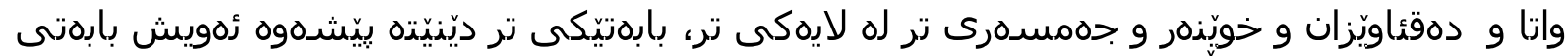

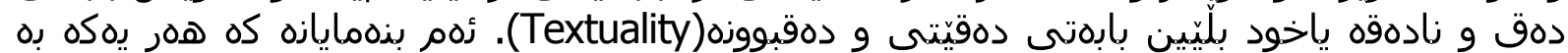

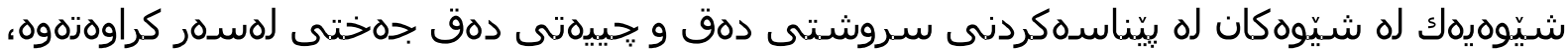

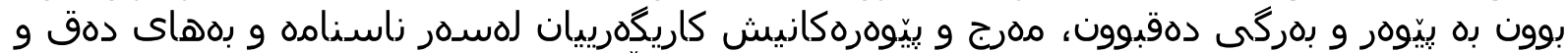

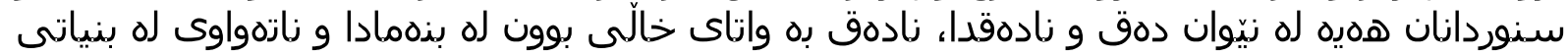

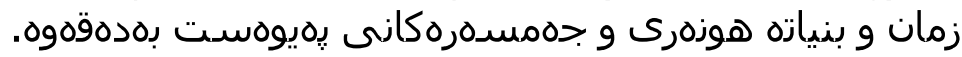

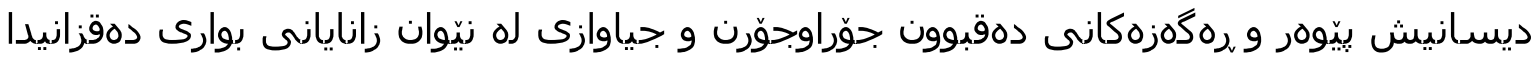

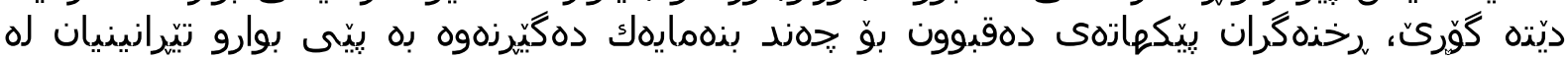

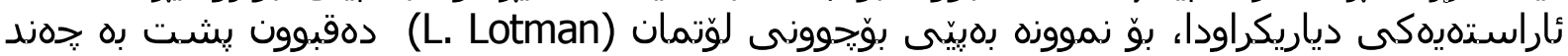

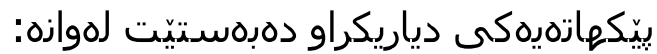

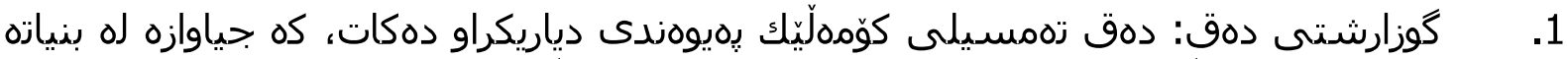

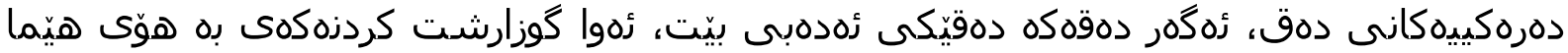

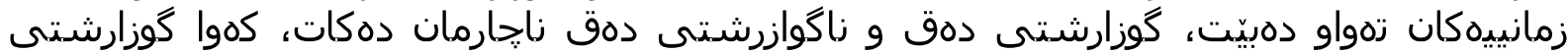

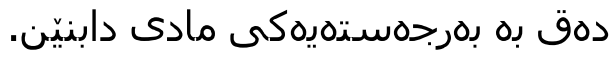

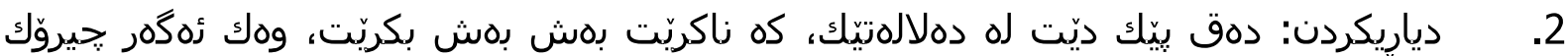

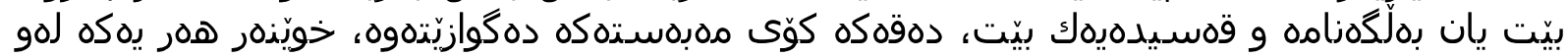

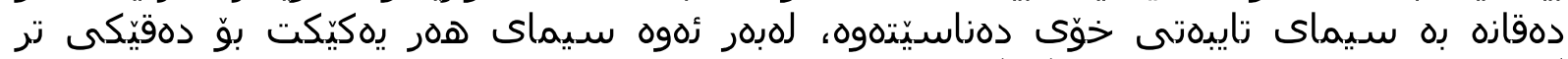

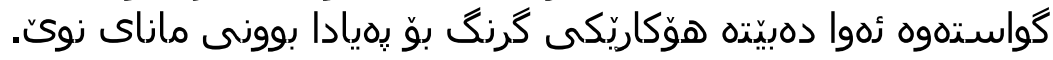

3. تايدهتمهندى بنياتى دهق

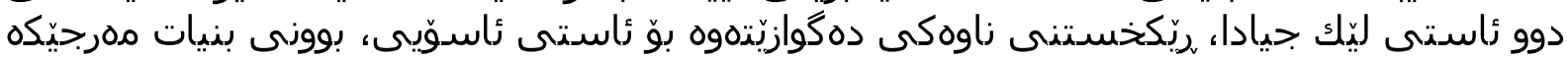

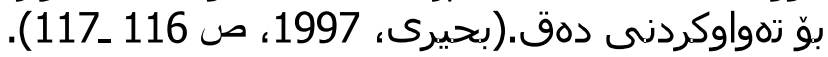

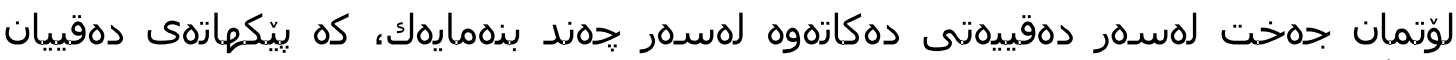

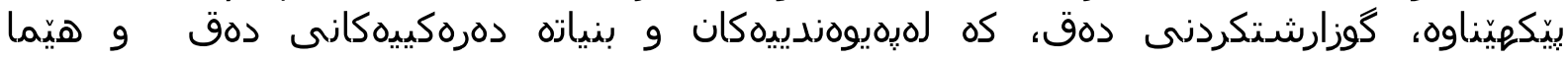

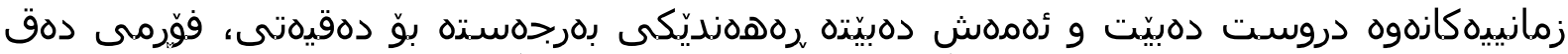

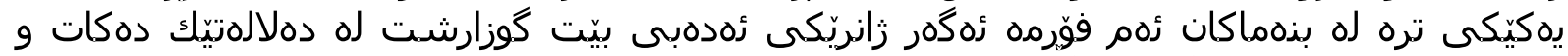

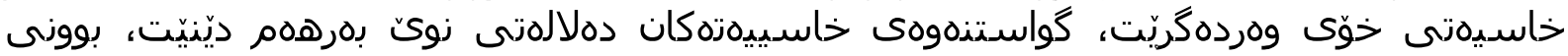

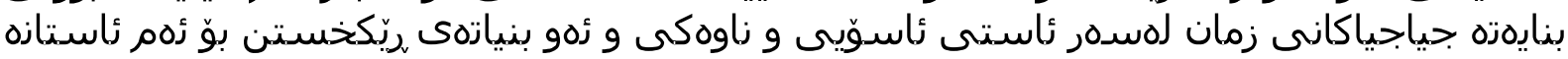

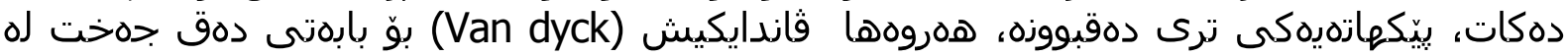




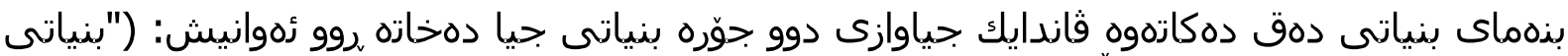

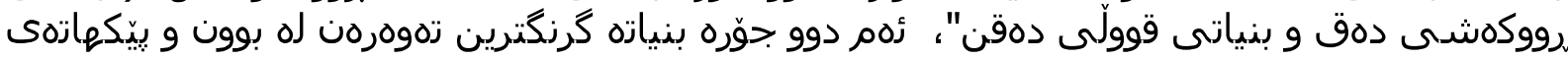

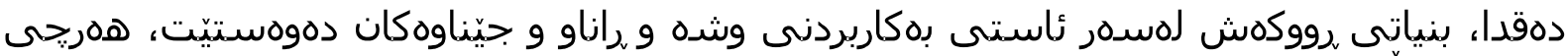

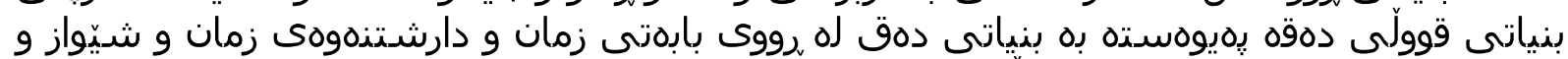

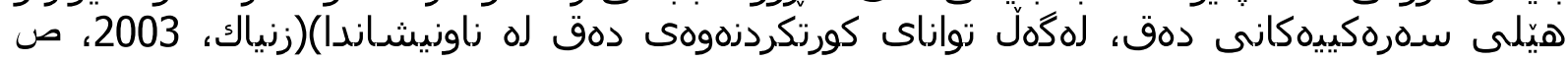

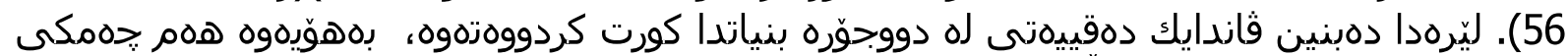

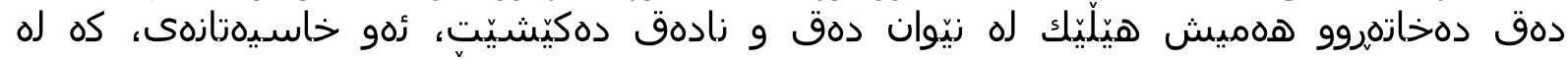

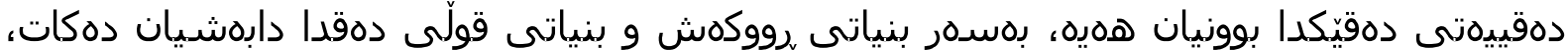

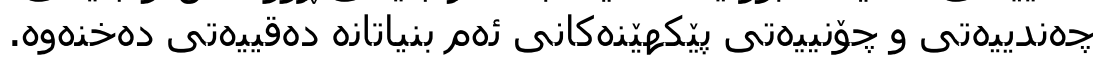

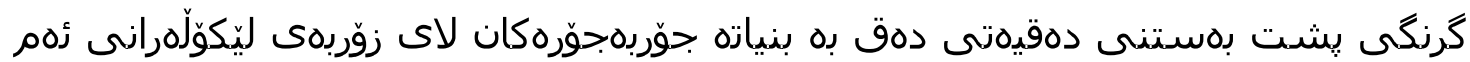

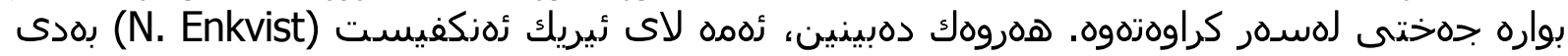

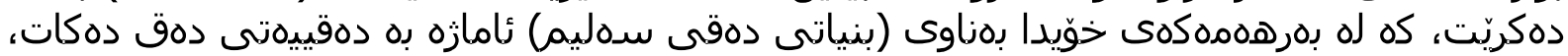

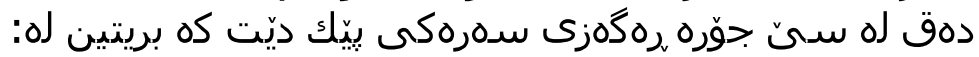

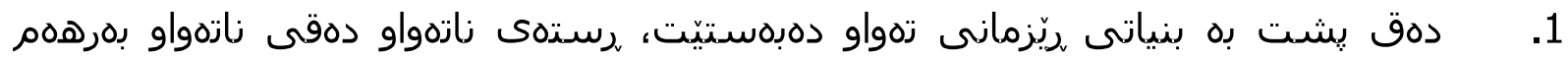
ديَنيَت.

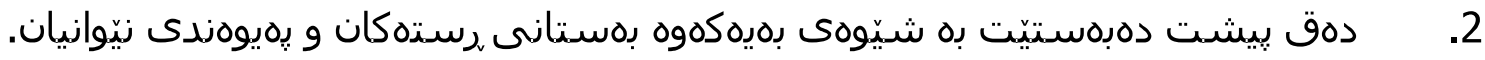

$$
\text { 3. دهق بشت به دهورووبره (سياق) دهرهستيّت.( انكفيست ، } 2001 \text { ، ص 113). }
$$

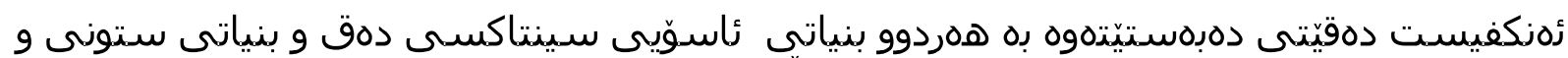

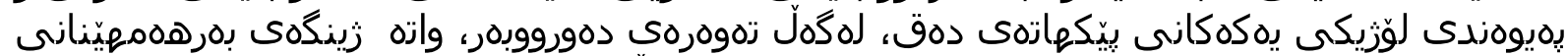

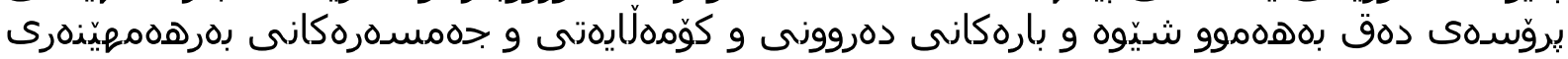

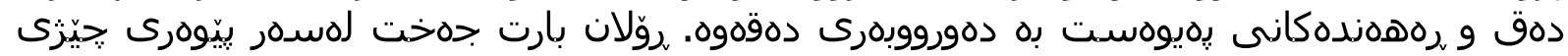

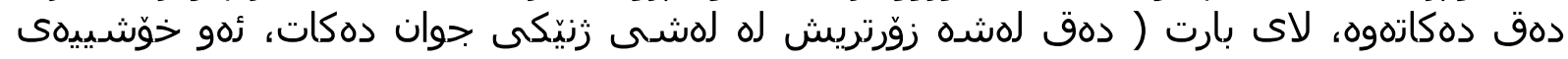

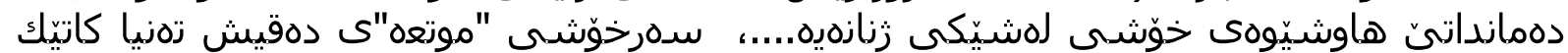

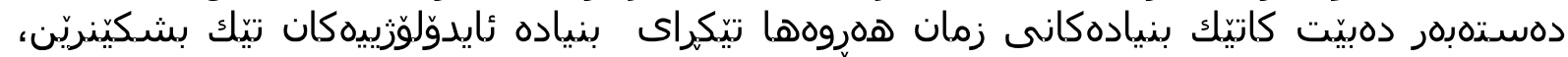

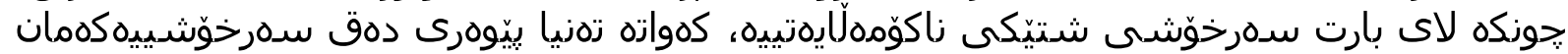

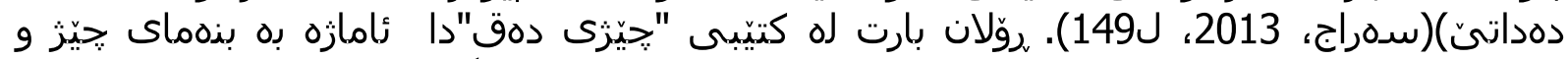

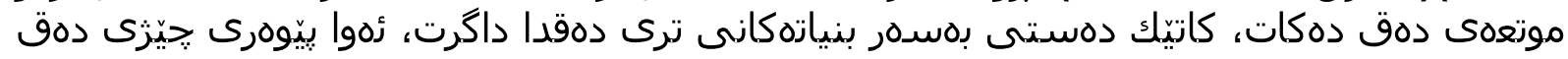

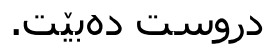

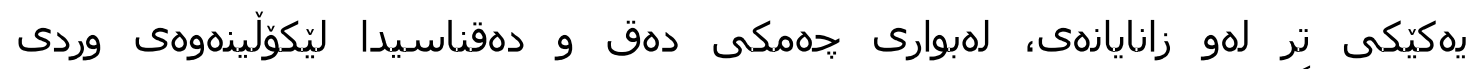

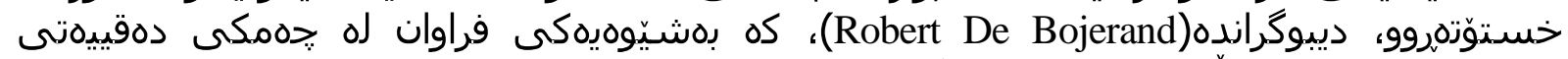

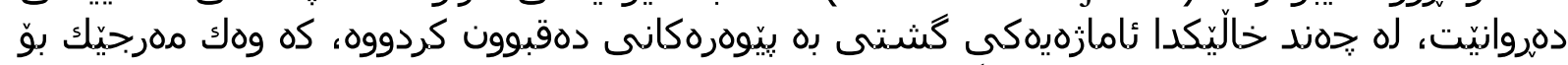

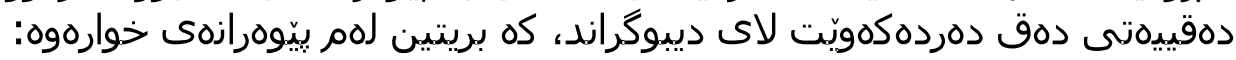

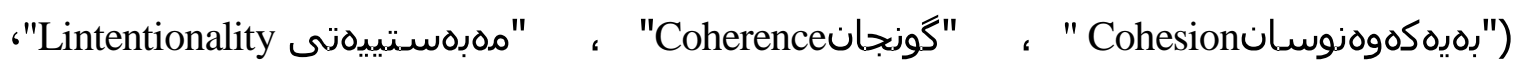

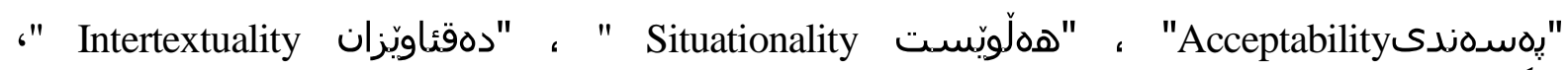

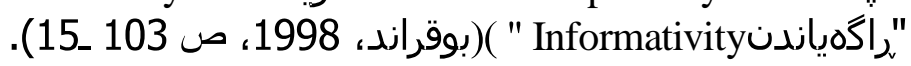

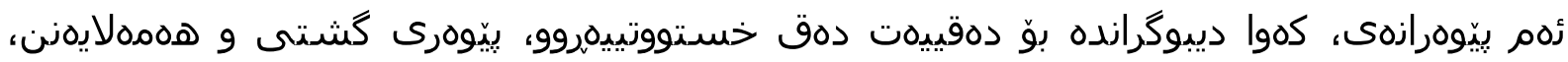

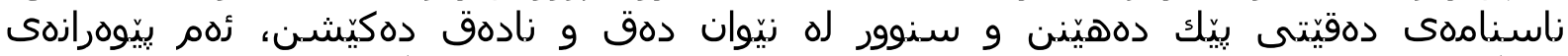

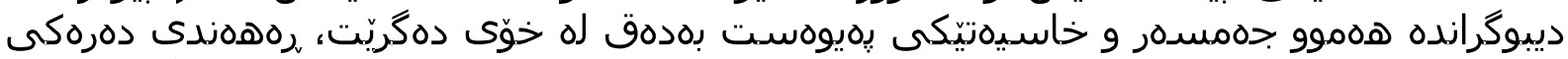

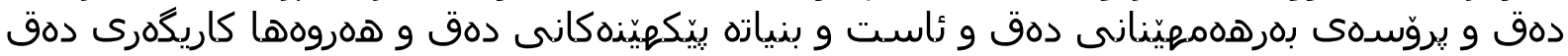

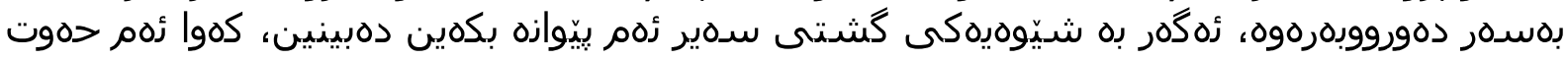

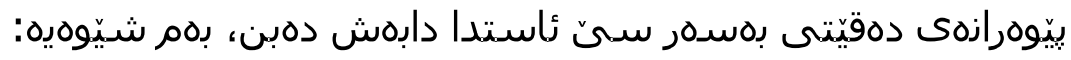

International Journal of Kurdish Studies Vol.5/1 ( January 2019) 


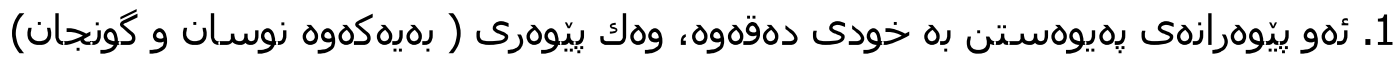

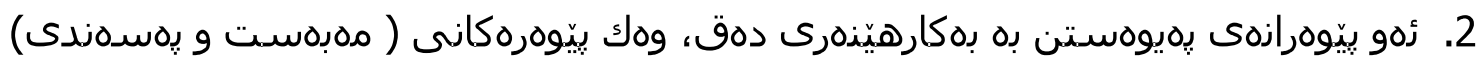

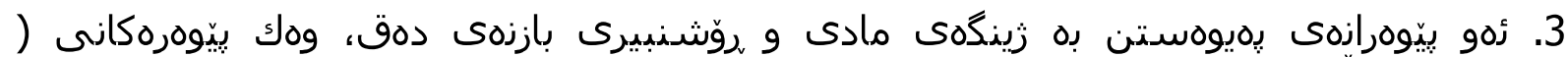

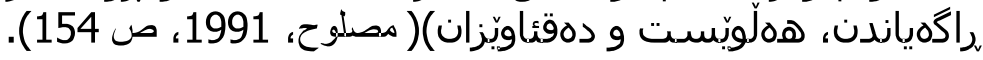

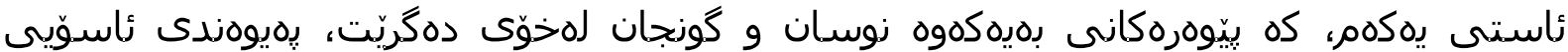

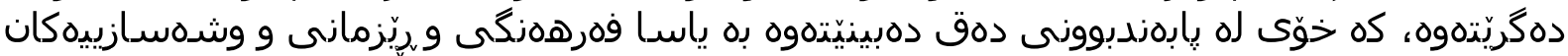

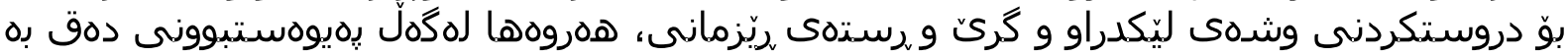

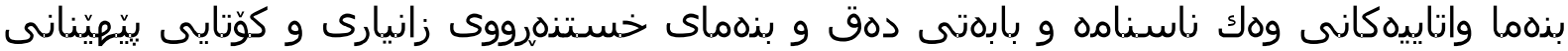

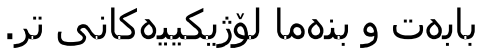

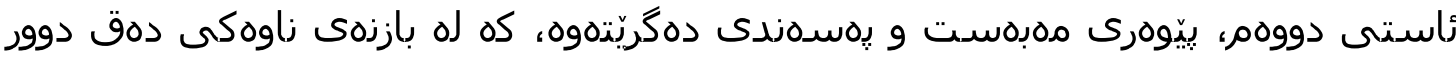

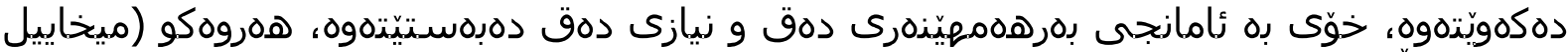

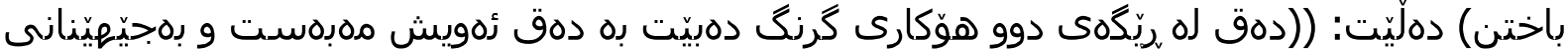

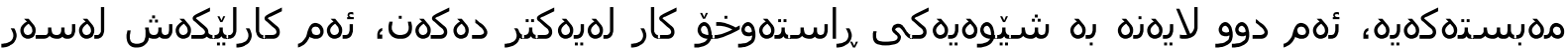

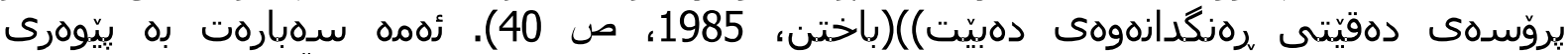

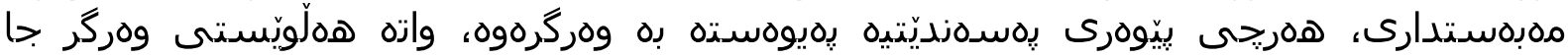

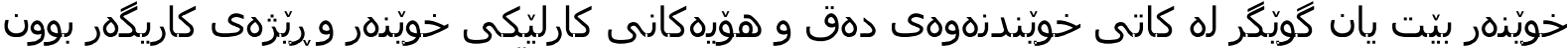

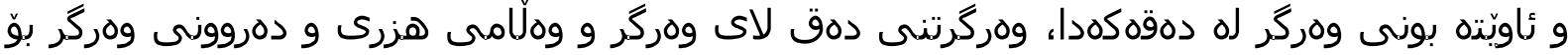

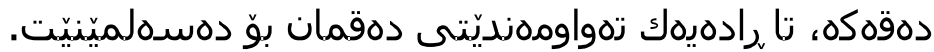

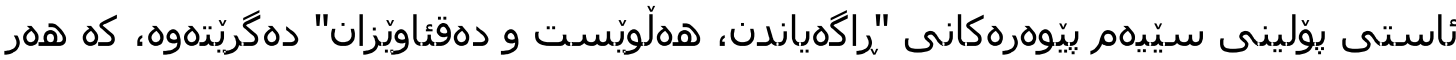

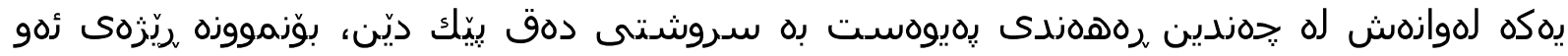

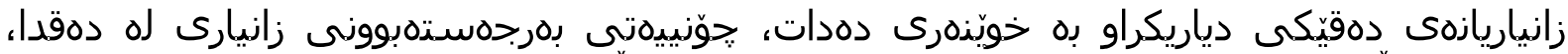

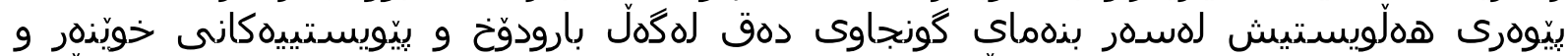

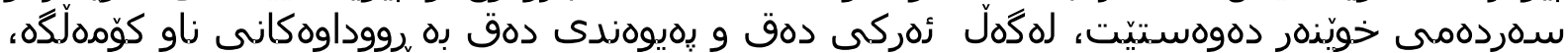

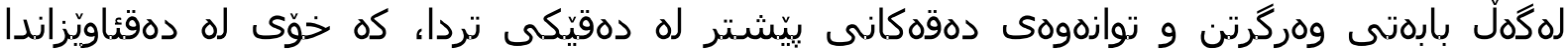

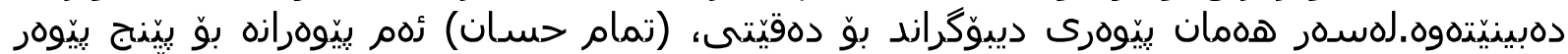

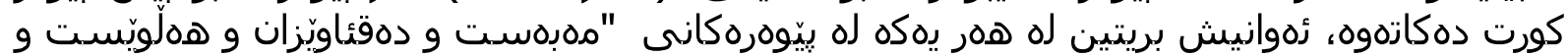

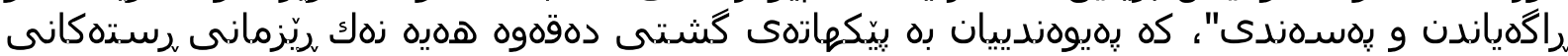

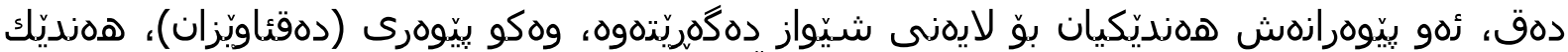

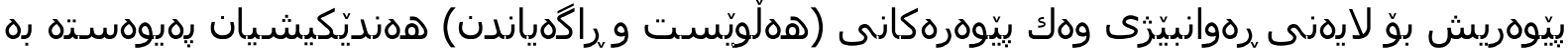

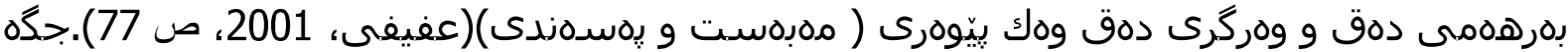

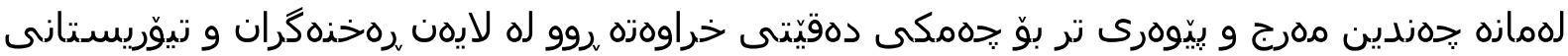

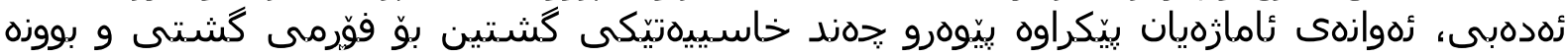

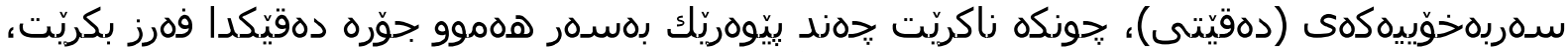

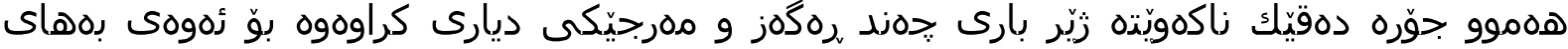

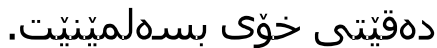

سروشت و تايبتهمهنديّتى دهقى زهدهبى

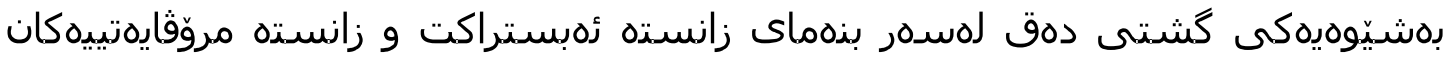

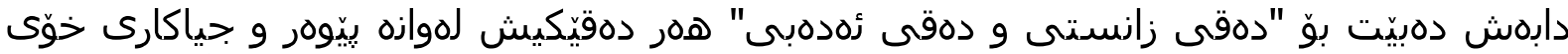

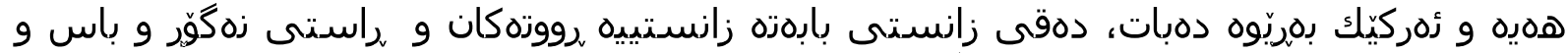

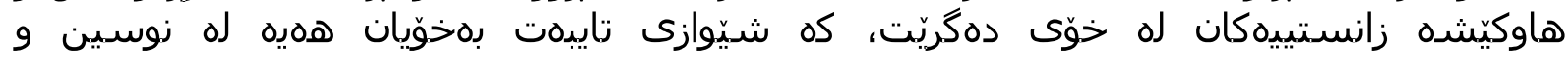

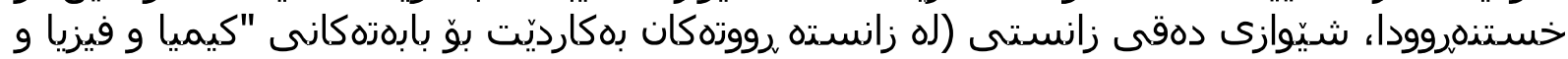
زٔهندازيارى و زانستى يزيشكى 


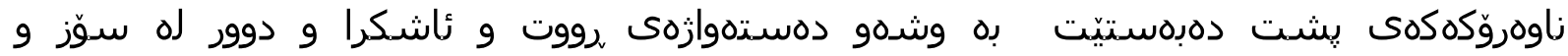

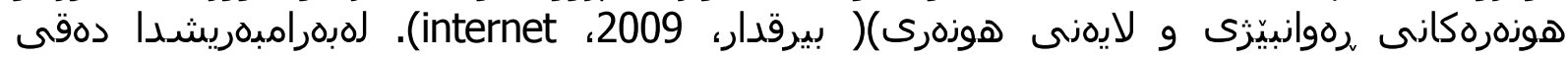

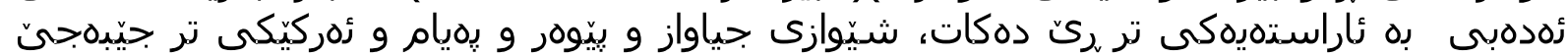
دoات.

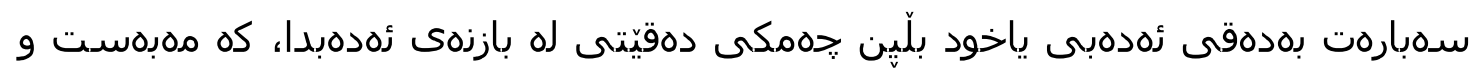

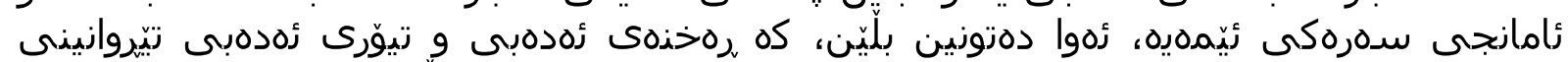

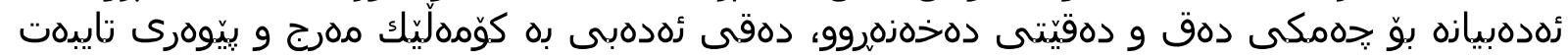

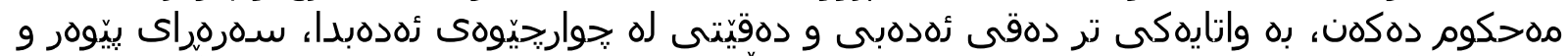

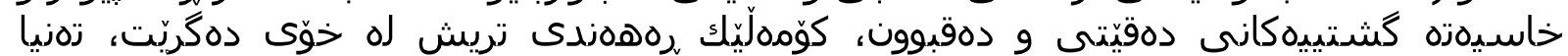

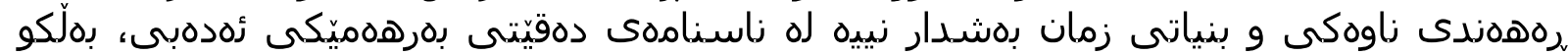

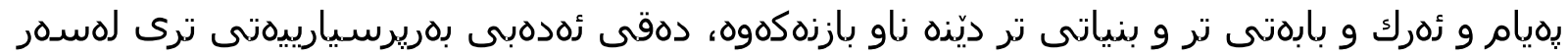

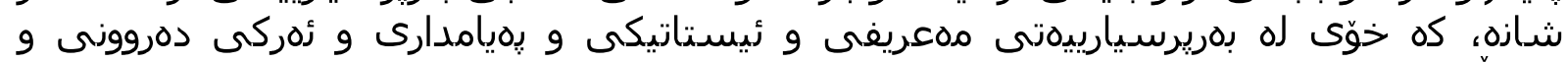
كوّمهلّايهتى

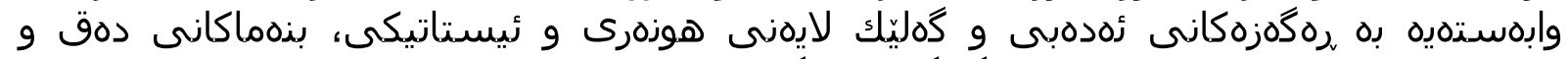

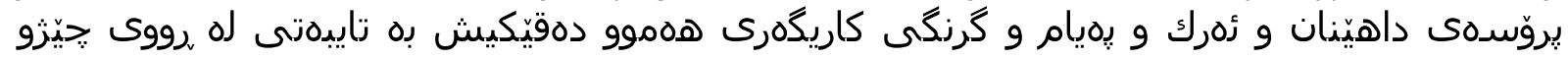

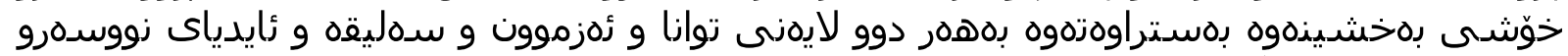

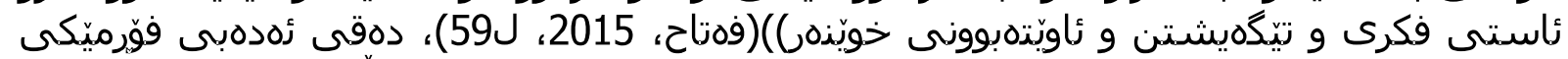

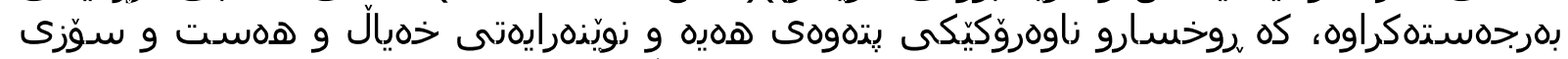

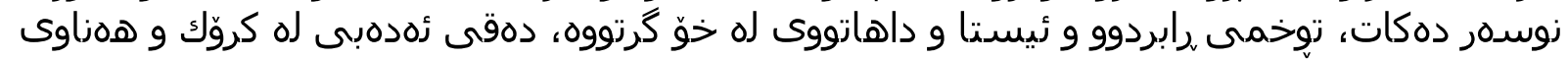

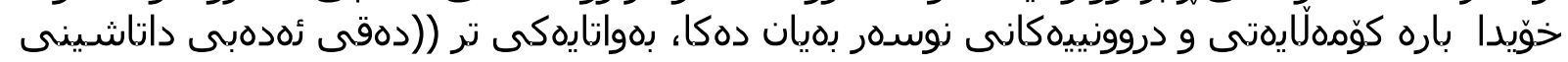

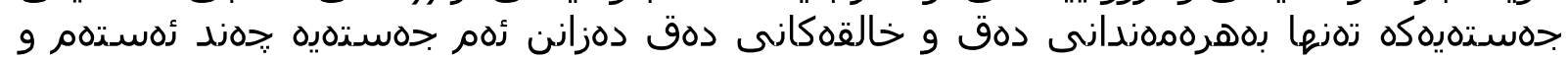

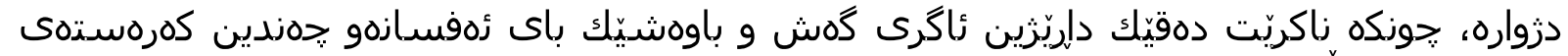

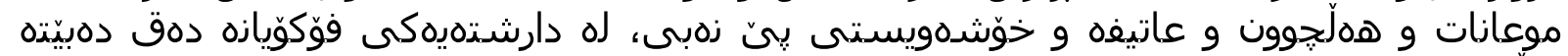

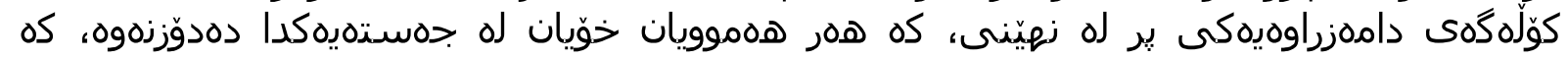

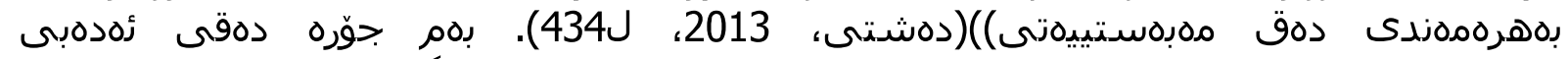

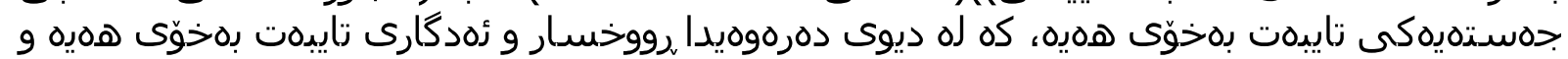

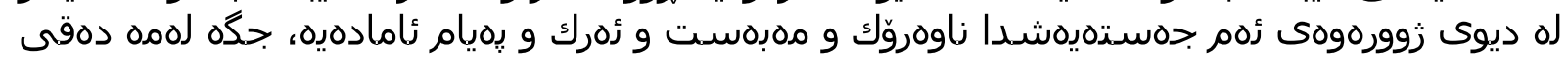

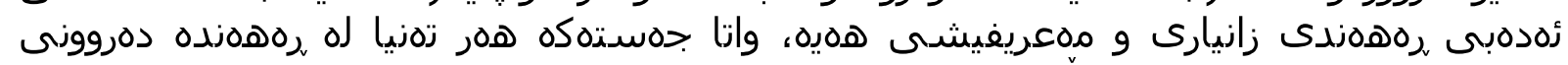

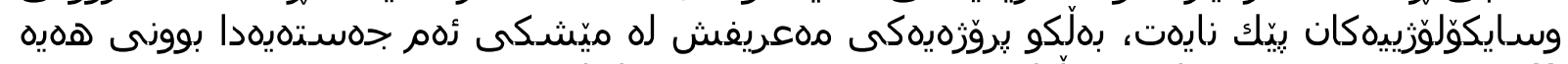

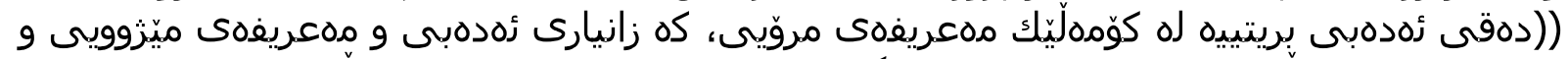

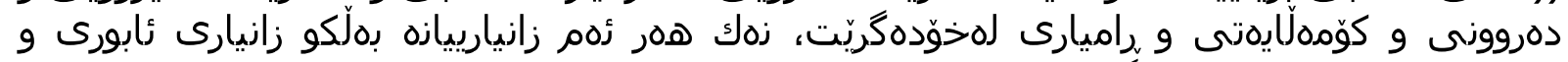

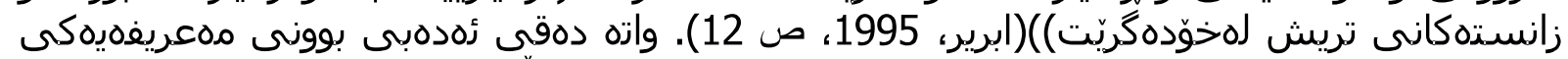

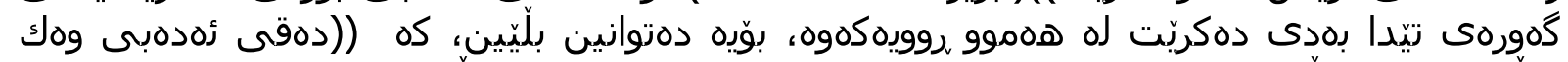

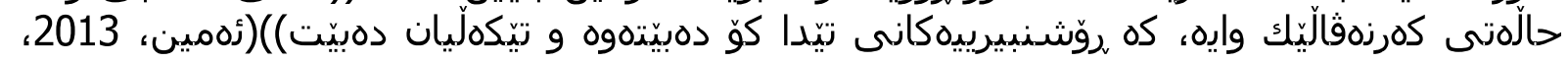

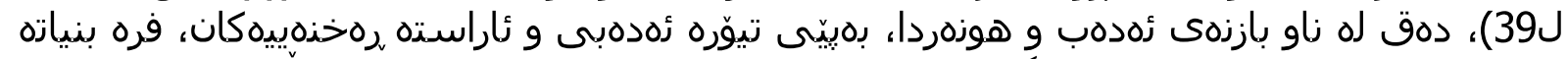

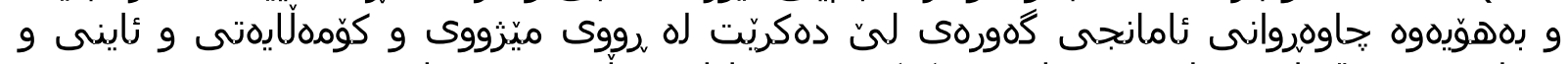
سياسى، دهوق لهو

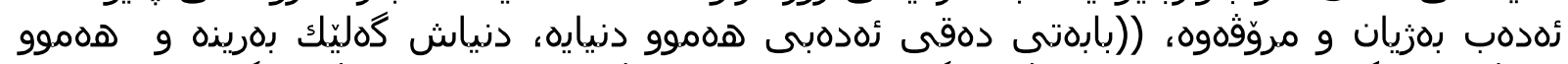

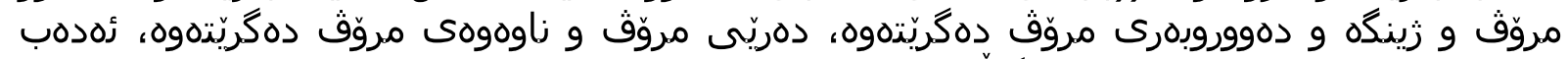

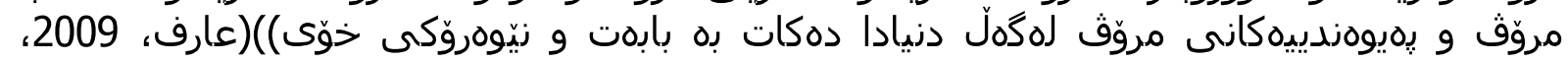

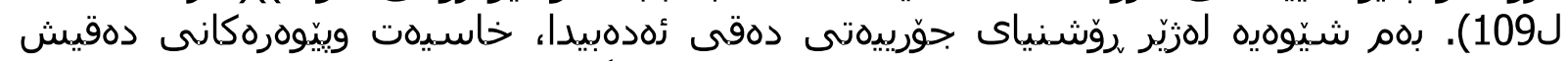

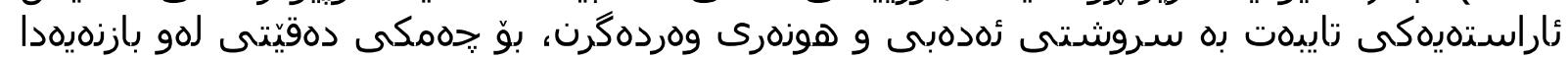

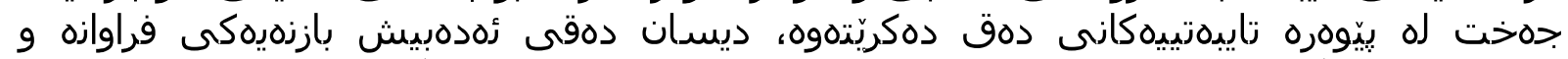

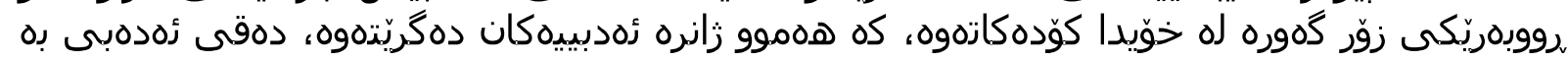

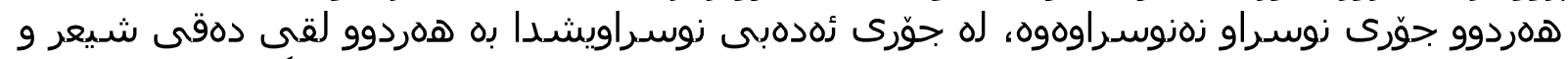

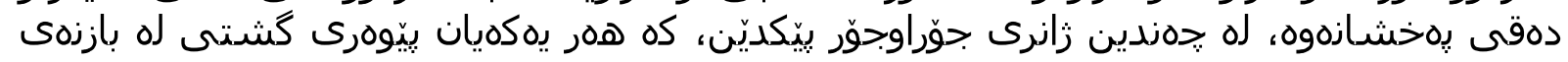

International Journal of Kurdish Studies Vol.5/1 ( January 2019) 


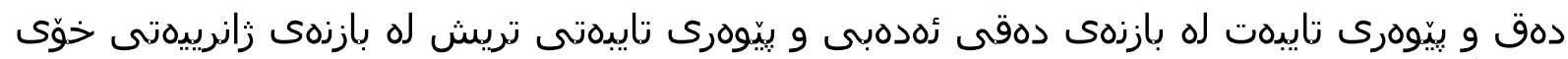

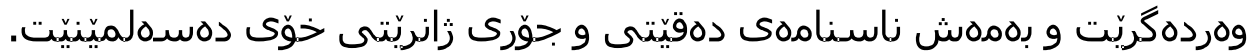

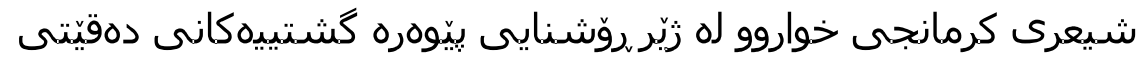

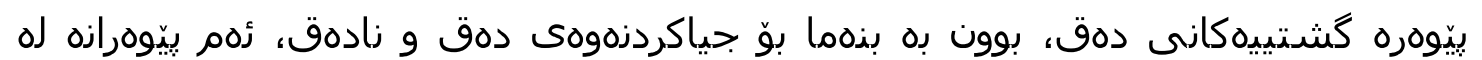

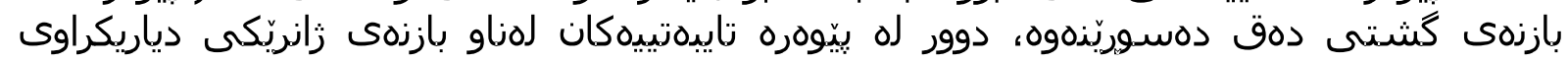

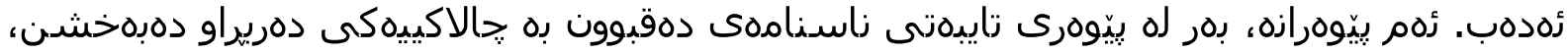

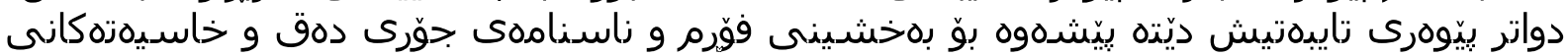

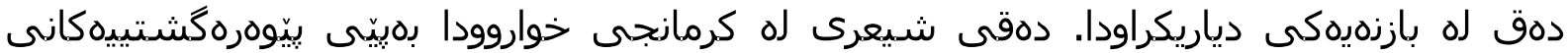

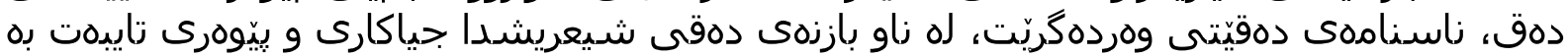

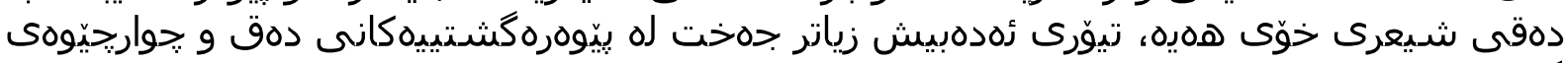

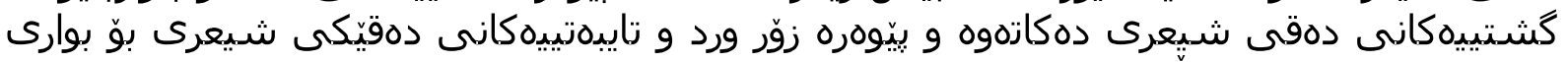

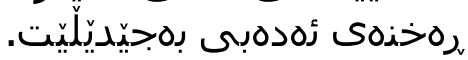

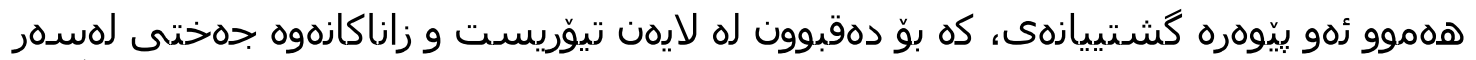

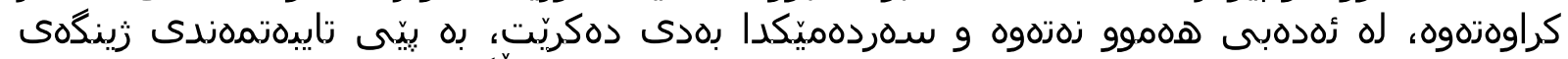

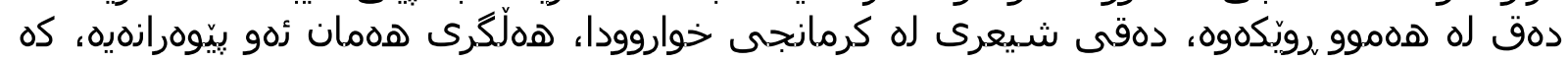

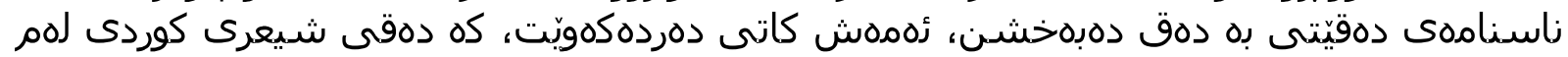

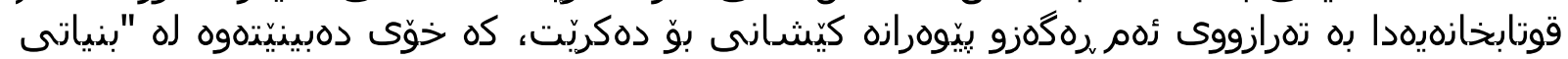

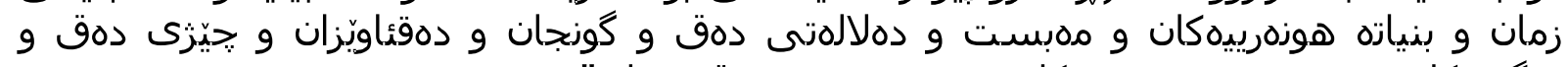

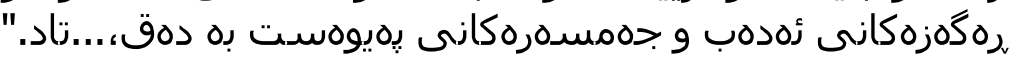

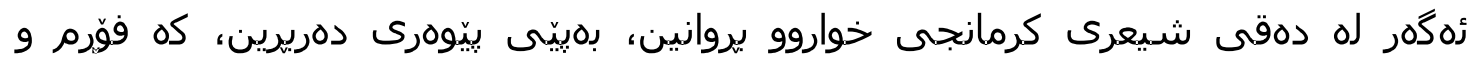

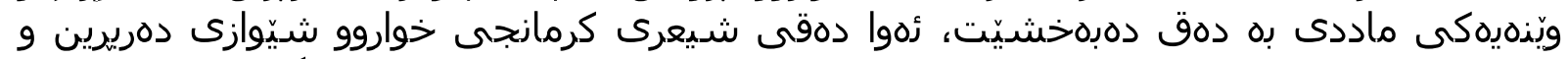

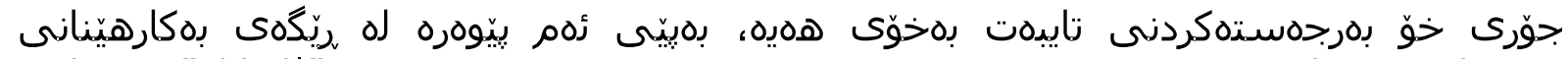

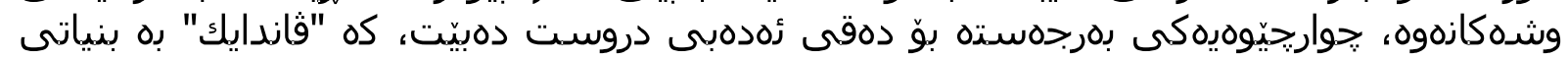

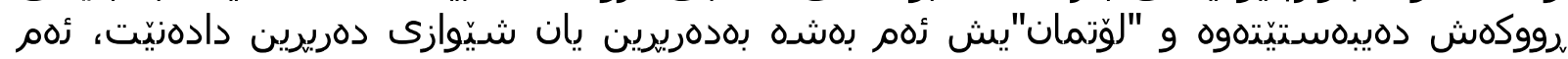

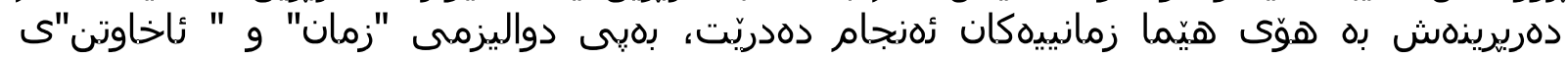

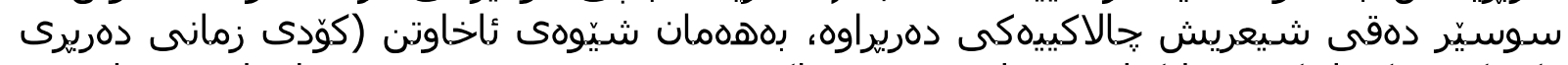

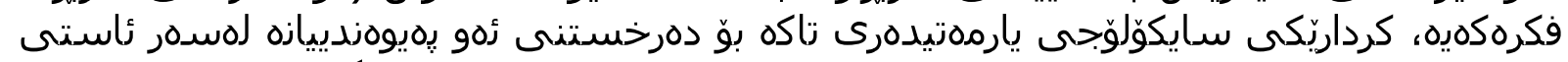

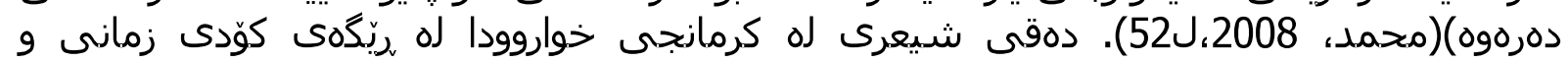

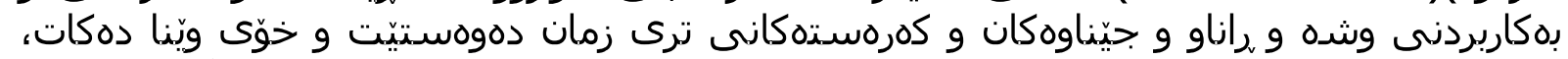

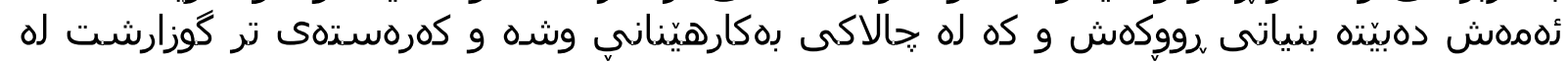

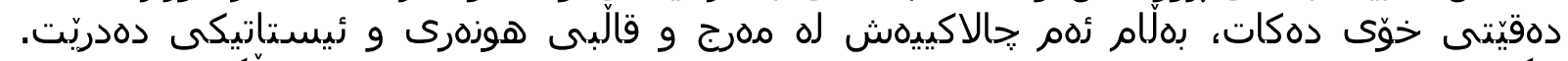

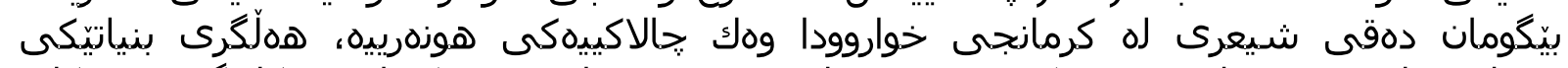

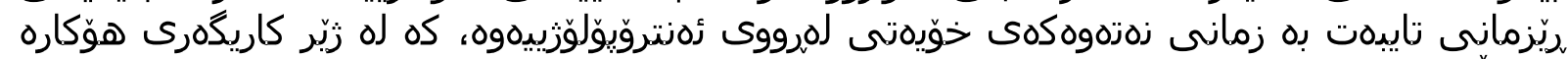

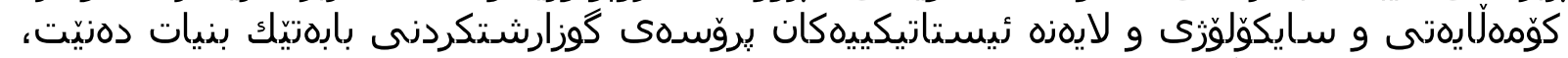

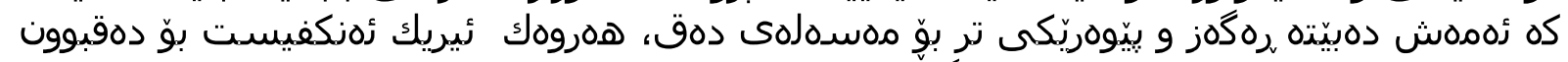

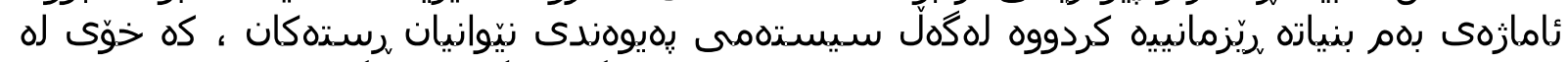

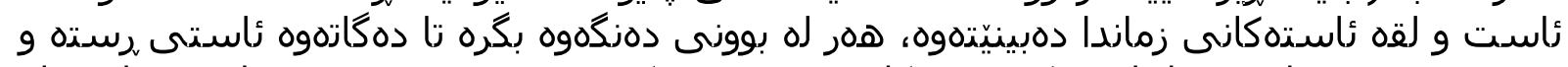

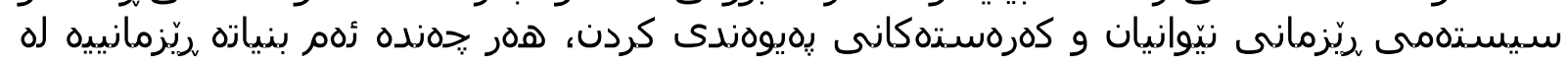

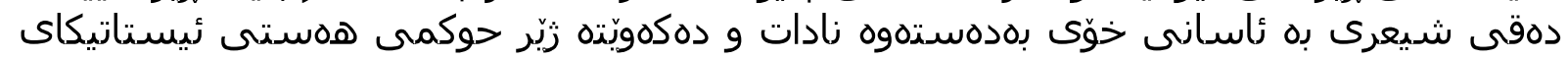

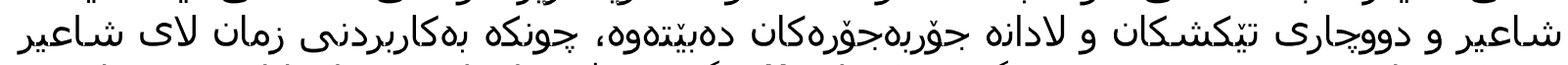

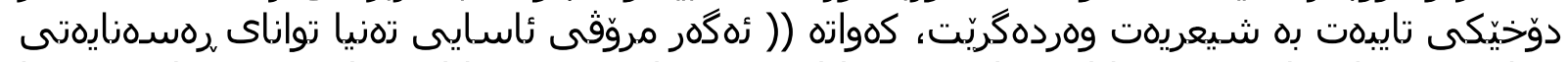

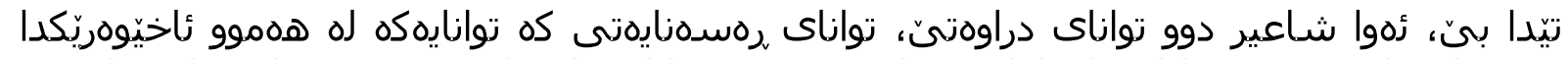

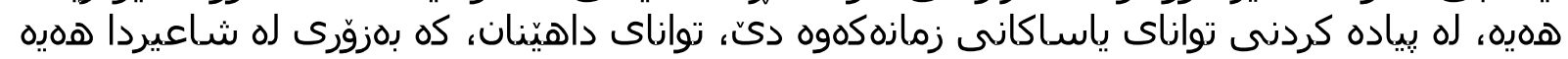

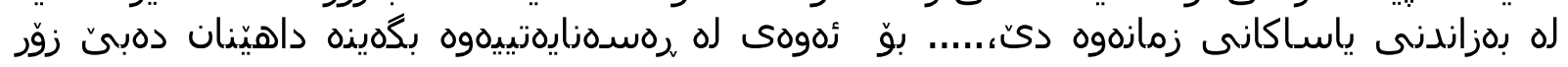




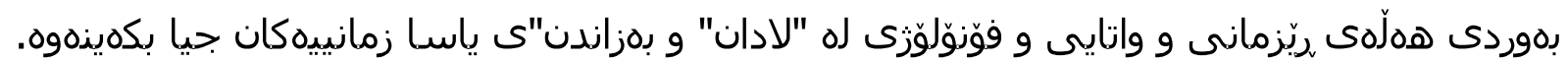

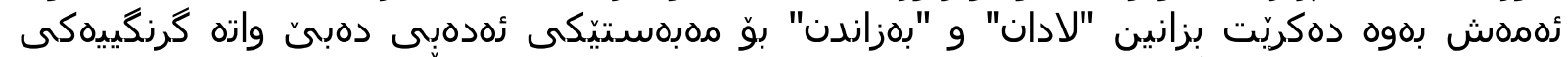

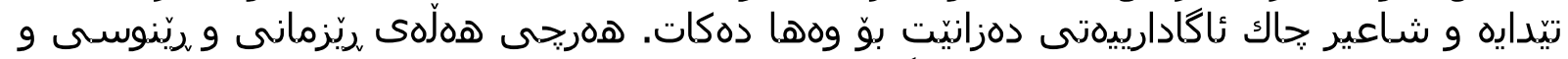

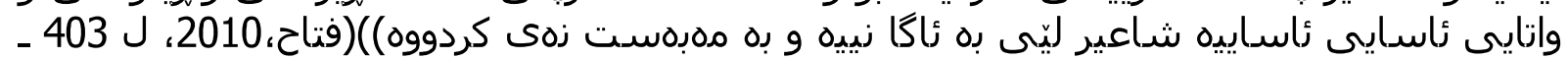

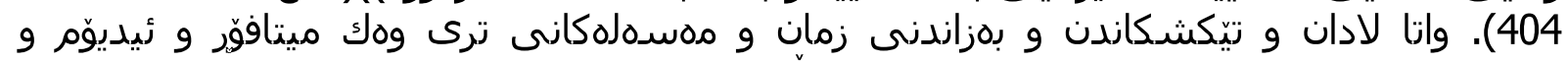

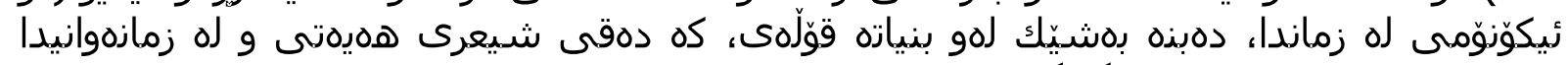

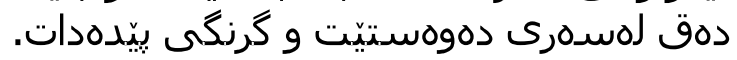

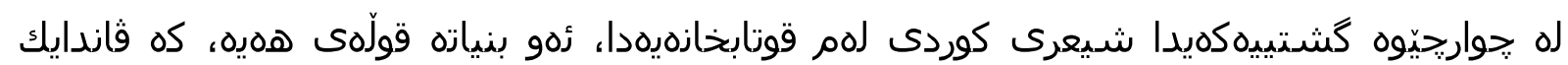

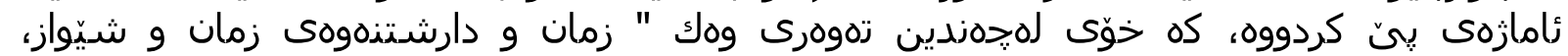

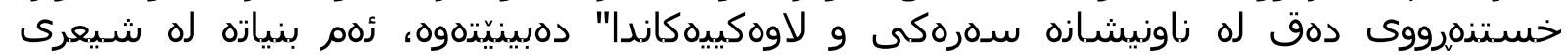

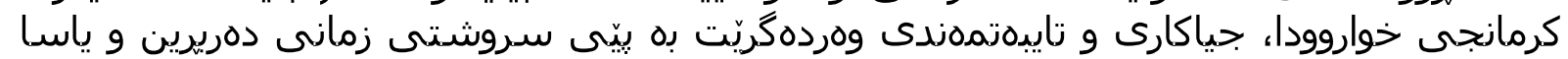
فهرهذنكى

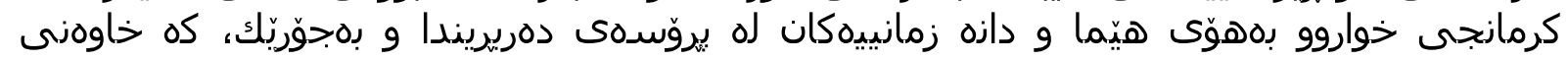

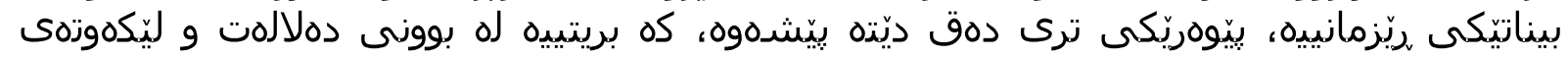

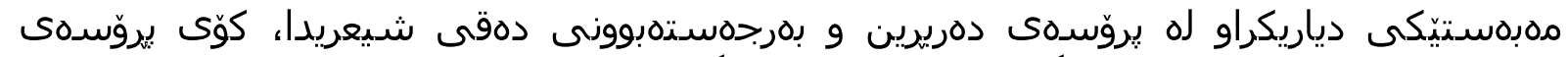

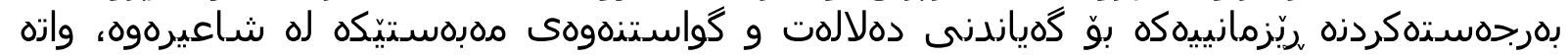

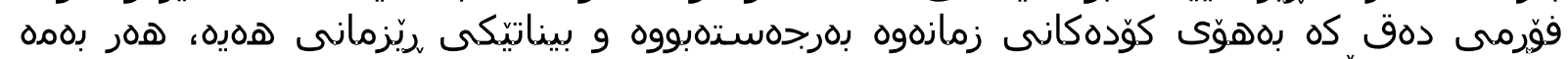

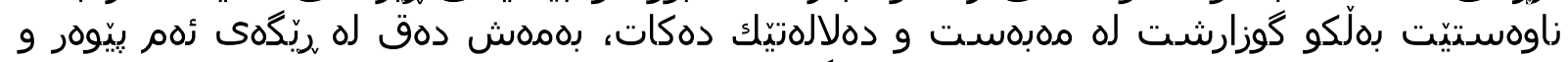

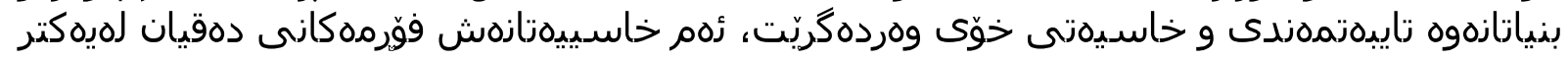

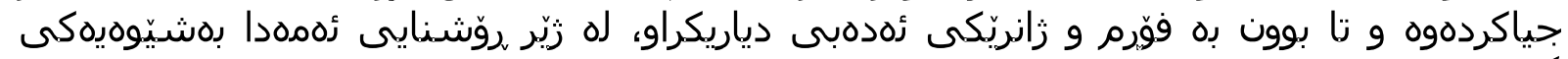

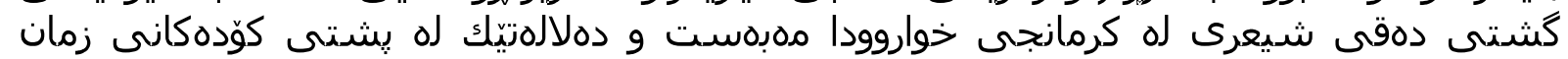

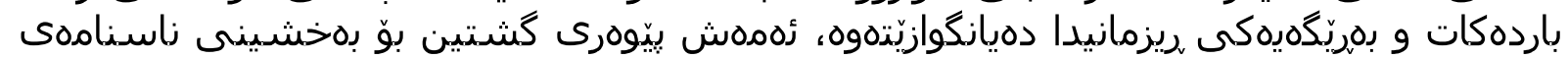

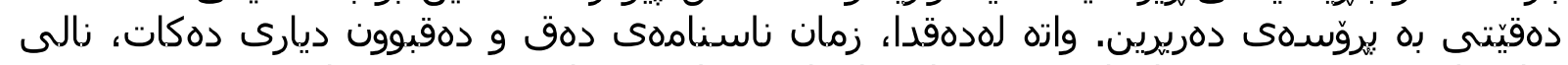

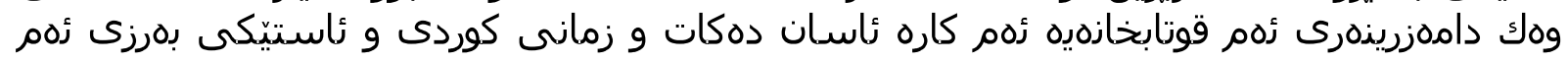

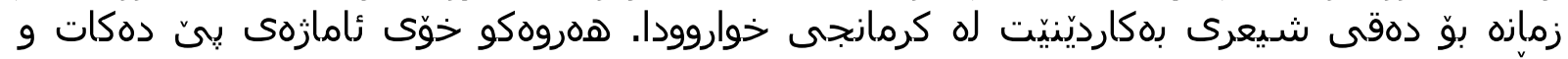
دهلِّيت:

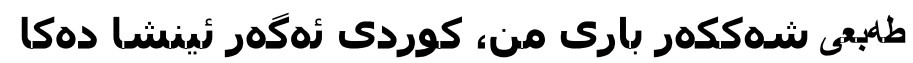
يميمتيحانى خوّيه مةقصودى ، له "عمدا" وا دمكا يا له مهيدانى فصاحهتدا به ميثلى شهه سهوار

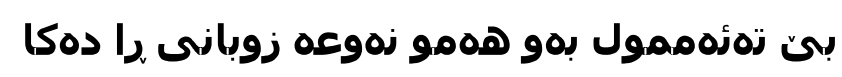
كهس به ئلفاظم زهلّن خوٌ كوردييه خوّ كردبيه همر كهسى نادان زهبى خوّى طاليبى مهعنا دهكا

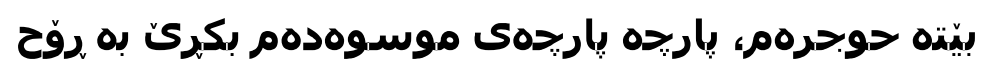
همر كهسى كوتالّ و باريحهى بیى به دهل سهودا دهكا شيعرى خهلّقى كمى دمكاته شيعرى من بوّ نازكى؟!

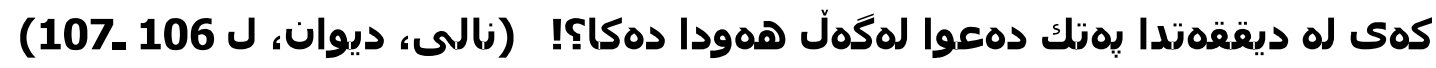

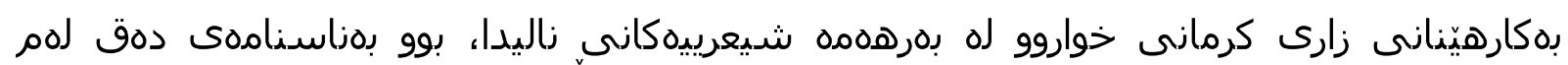

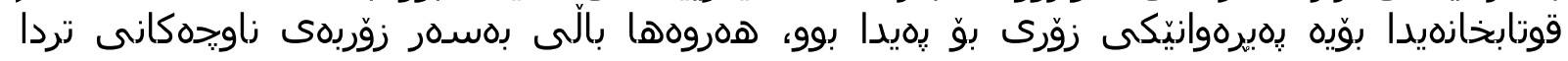
كيّشا. 


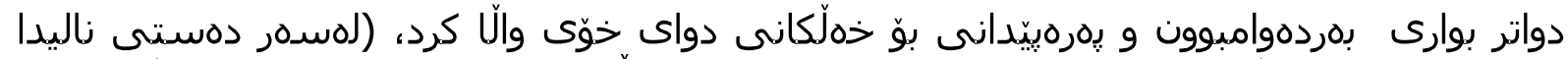

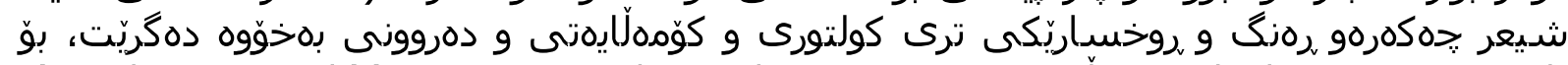

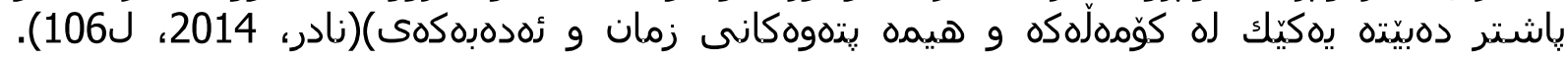

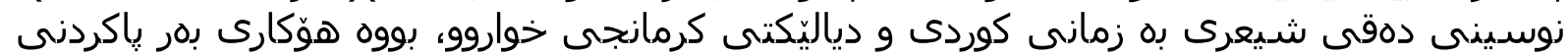

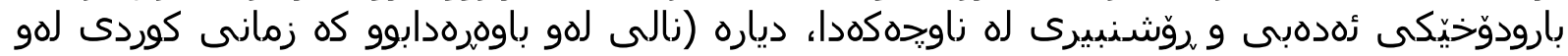

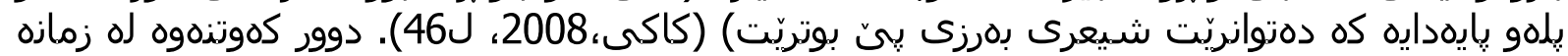

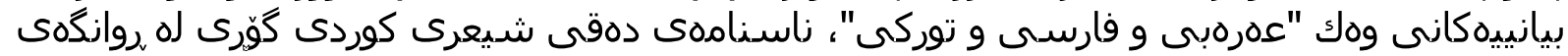

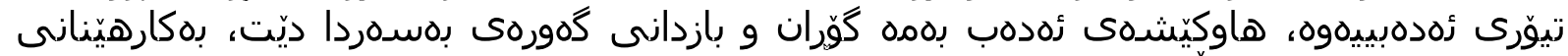

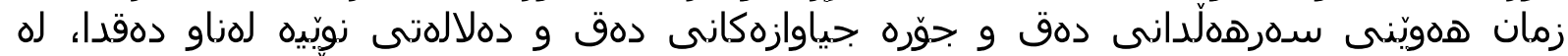

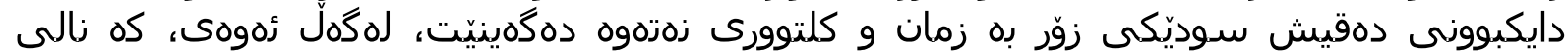

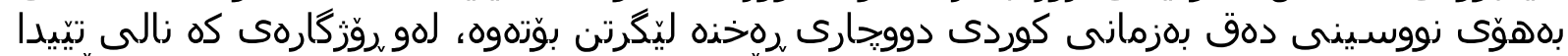

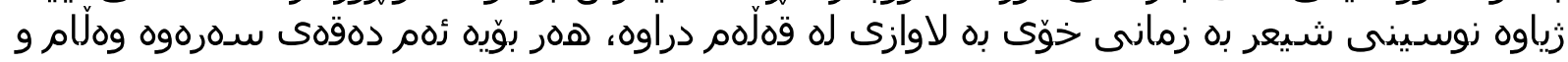

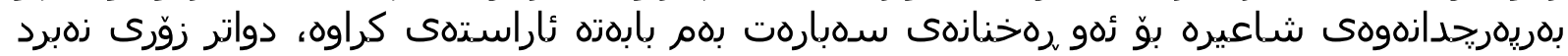

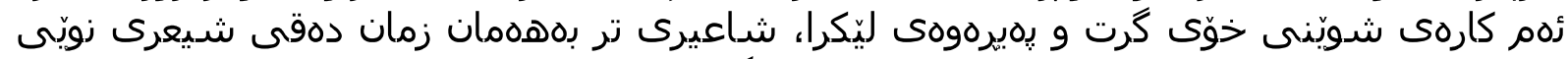

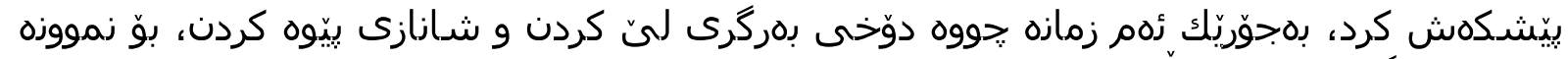

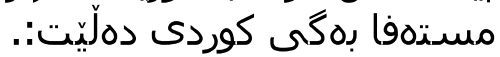

كوردى مهستى دهردى بادهى عيشقه، ويّردى نظمى ورد

(كوردى، ديوان، ب1،

دهردى هيجره كَر به حهرفى كوردى ههر يارى دماك

(61J

مهلّين "هيجرىى" له زيّدا كوردييه، بيللا له حهشريشا به كوردى " كوردى" دهعوابح حمقى كورده و ههر ئهيسيّنى (كوردى، ديوان، ب2،

(251)

زٔهم بهركرى كردزه لاه زمانى كوردى و

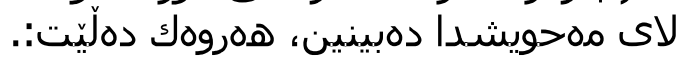

كوردى زوبانى نهصليمةكهر تهركى كهم بهكول

بو فارسى، بهكوللى نهمن دهبمه بن وهوا

دورى مهبينه توّ له كهريمى بههانهجحو

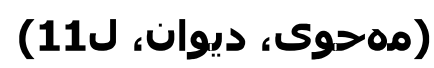

همريحى كه كورده بְاكى بمهشى به (بولوهوا)

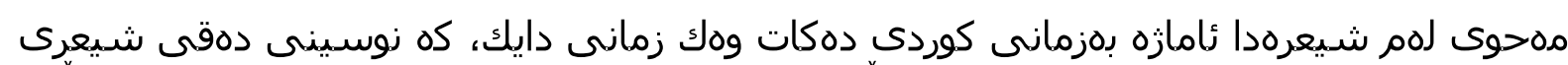

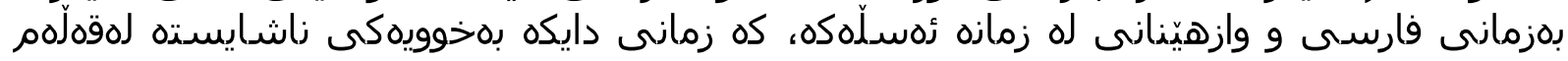

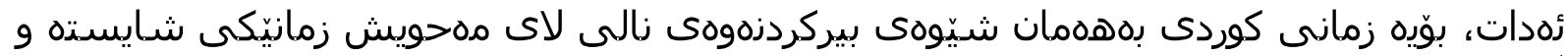

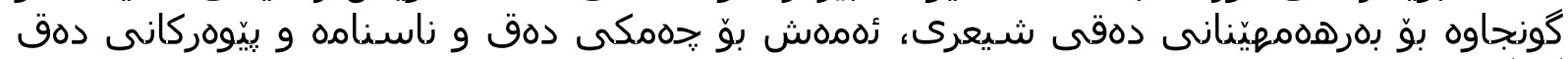

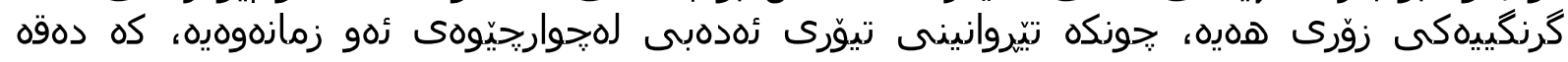

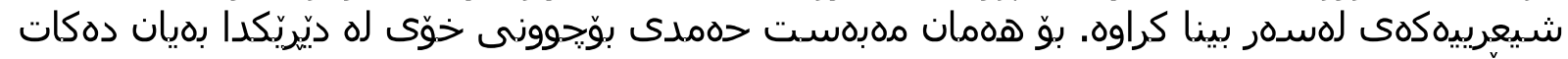
و دهليّيت:

كَول لهبهركى سهوزى خويدا ناسك و شيرينتره (230)، (200)، ديوان) بوّيه فيكرى زازكى حهمدى به كوردى بِيَردا 
زهم زٔامازهكردزه به زمان و زمانى زهزهوه لاى حاجى قادرى كوّيى زوّر بههيّز و به تينتر دهردهكهويّت، هذروك دهليّت

شهبيهى جحوّله كه رازى نهبى، به سهردرى خوّى

(حاحى، ديوان، ل37)

(حاجى، ديوان، ل57)
مهلّين فهصاحهتيكوردى به فارسى ناكًا

مهفקومى دوو حمديسى صdحيحم له بهيتها

جى كردهوه زهزهر بكه كوردى و فهصاحهتى

نهذَر كورديّك قسهى بابیى نهزانى

(حاحى، ديوان، ل(58)
موحمققهق داكى حييزه بابى زانى

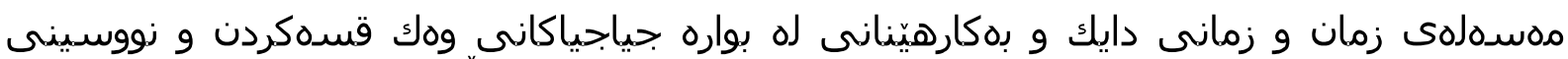

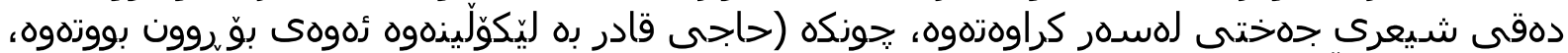

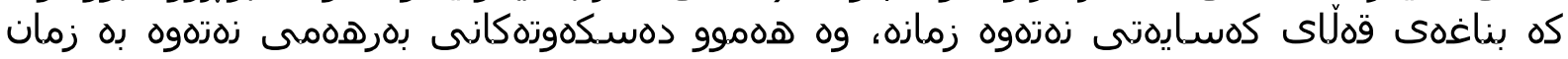

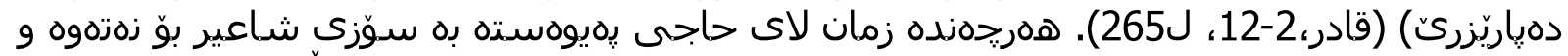

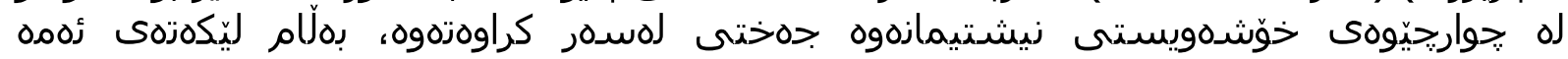

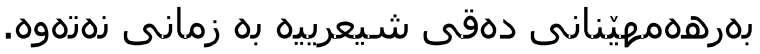

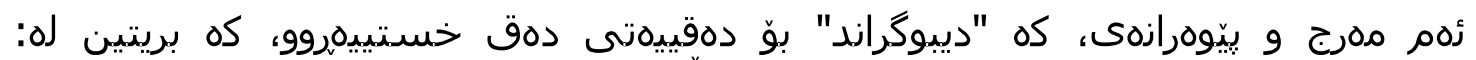

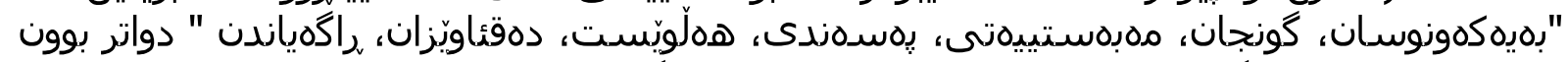

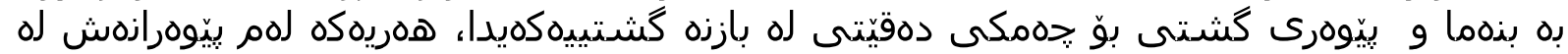

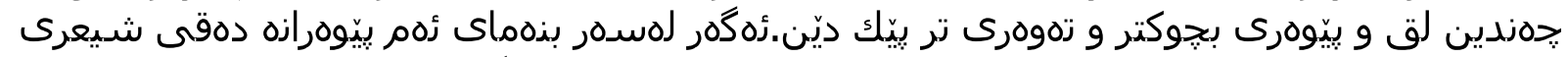

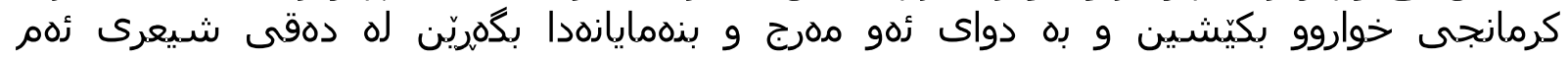

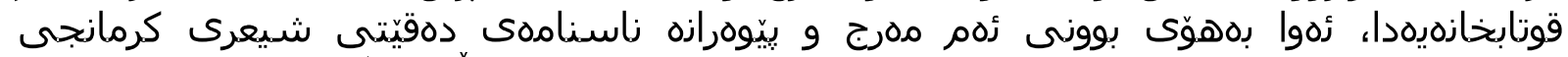

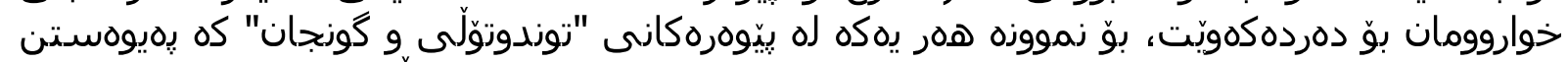

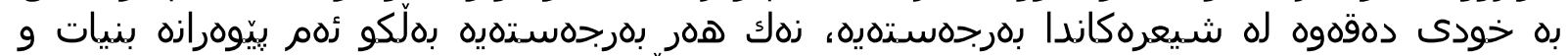

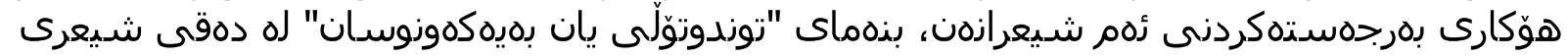

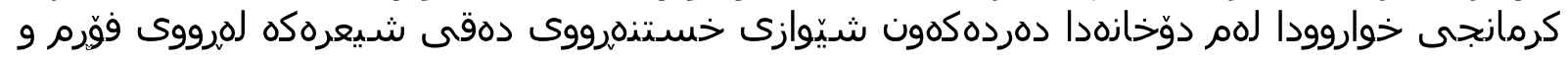

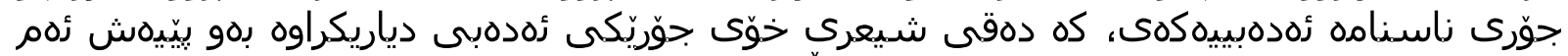

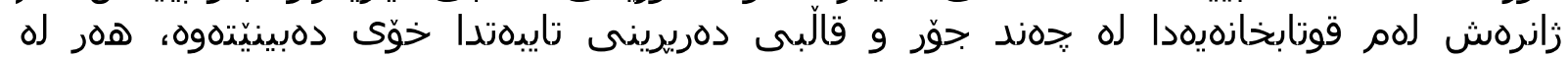

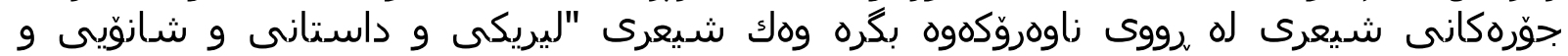

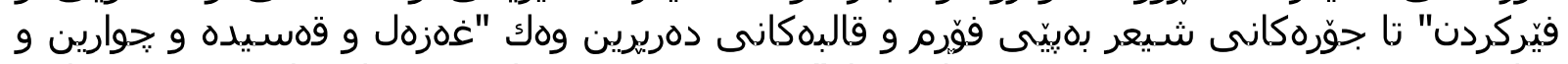

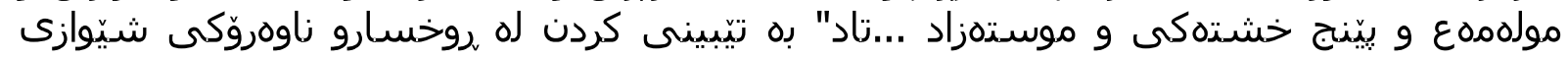

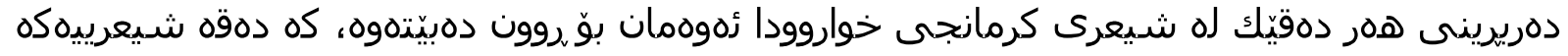

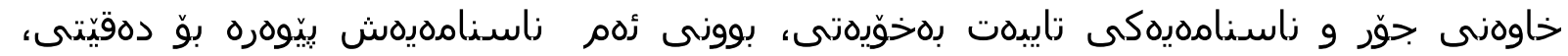

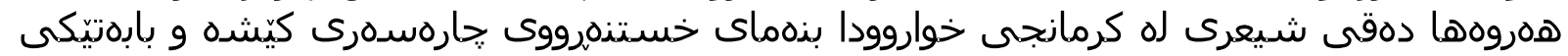

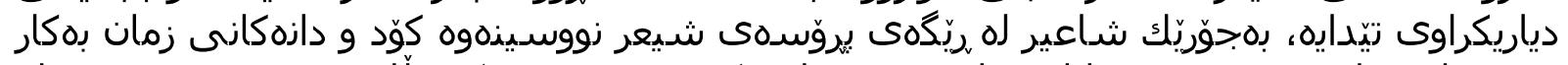

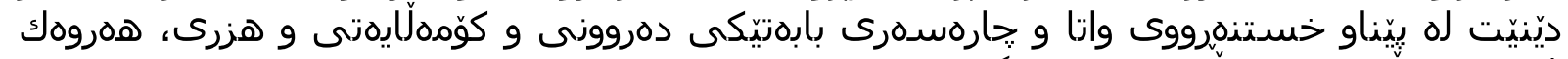

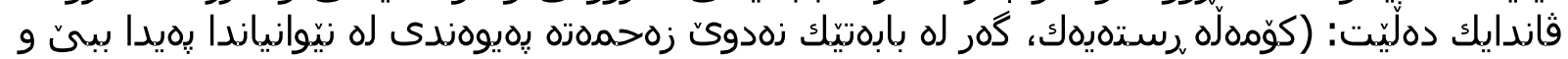

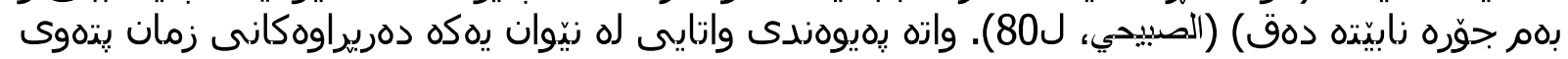

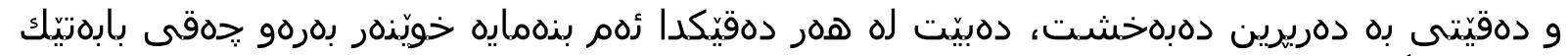

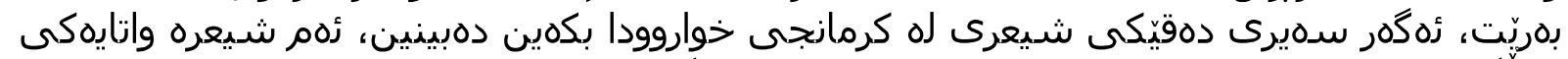

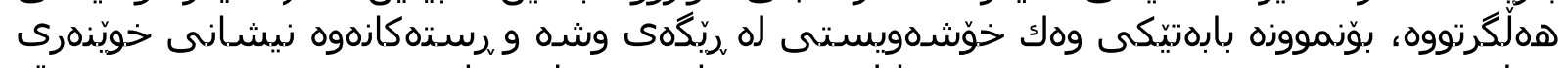

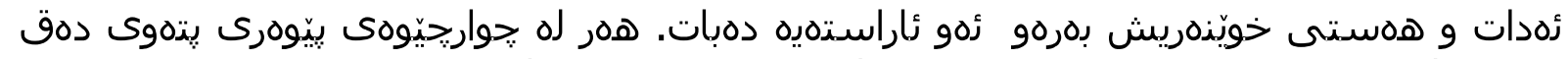

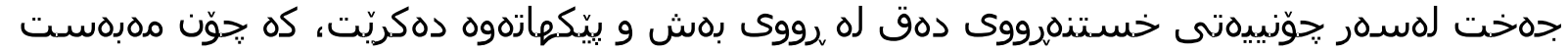

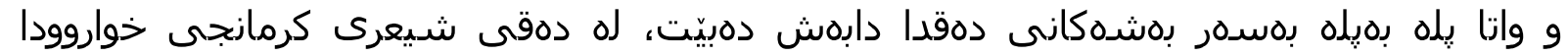

International Journal of Kurdish Studies Vol.5/1 ( January 2019) 


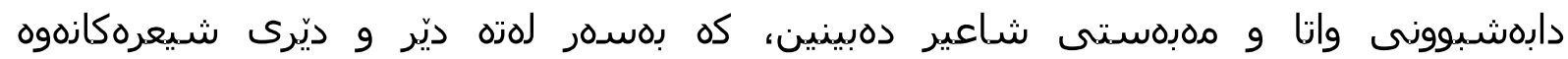

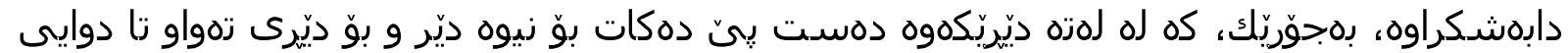

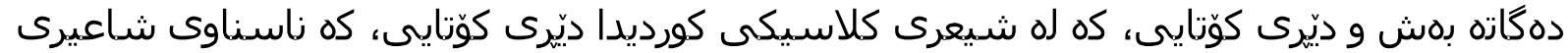

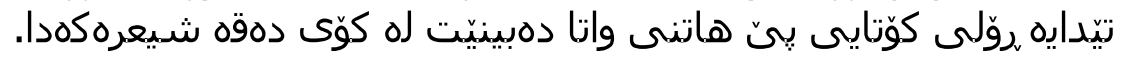

(نالى، ديوان، ل657) خهلّقى كه هممو كودمكن و بهسته زوبانن، با بِين و له "نالى" ببيهن شيعرى سهليقى

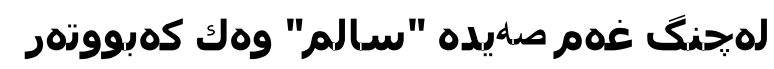
(سالم، ديوان، 2015، ل728)

دلّ له ئيدراكى حهقيقهت بیى بهشه بى داغى عيشق

\section{(مه>وى، ديوان، ل19)}

"مهحويا" دانا دهبي بهم :حاوه بينايی بكا

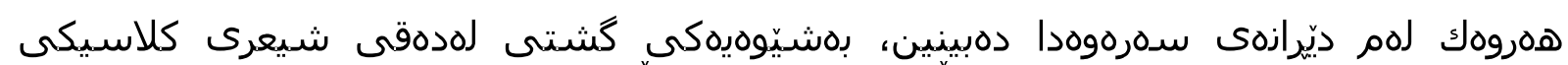

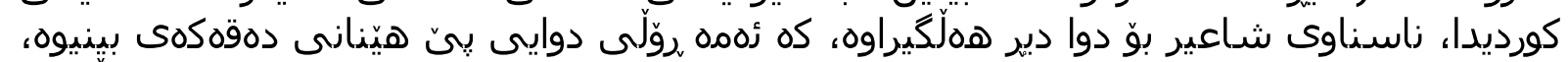

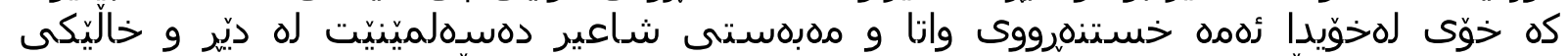

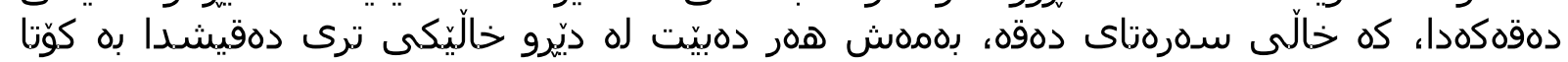

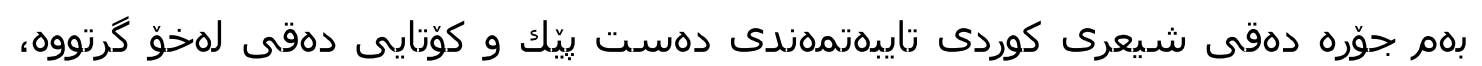

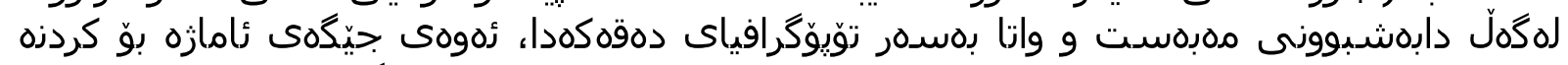

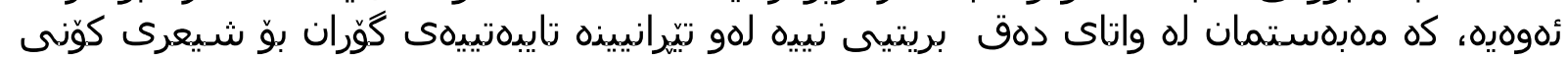
كوردى وهك سهره مهربه

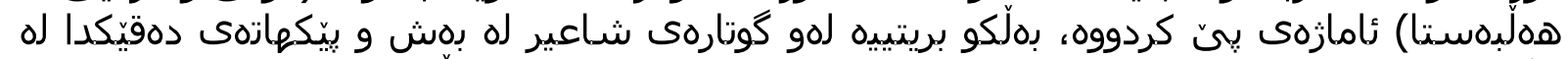

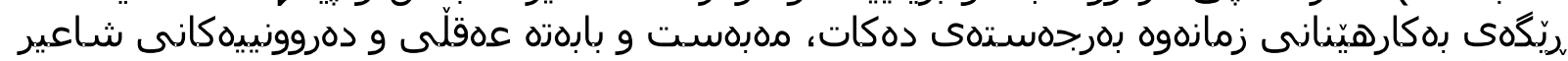

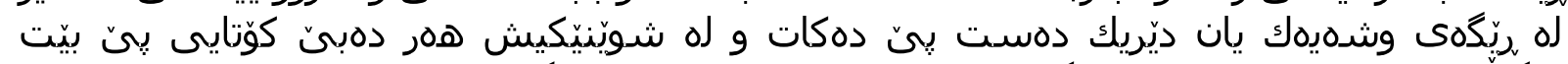

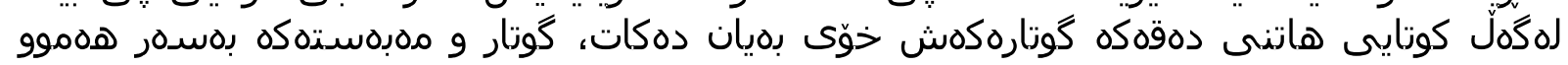

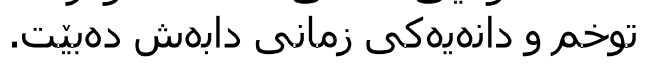

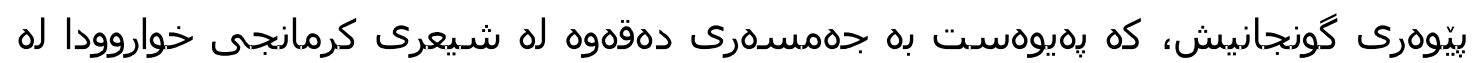

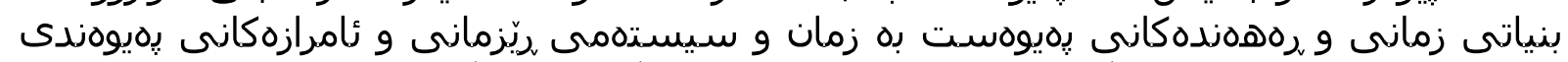

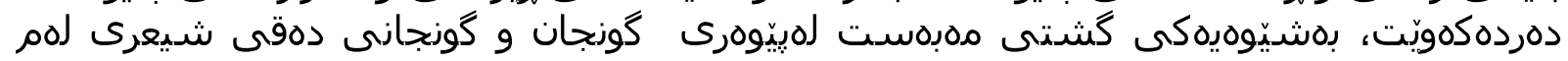

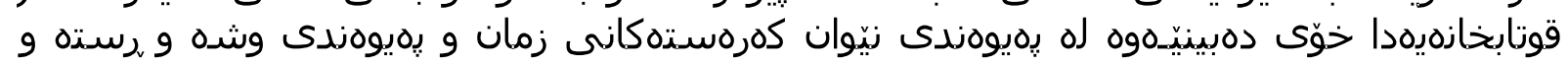

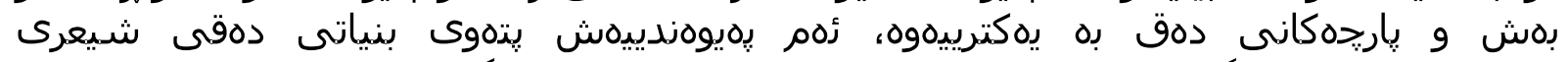

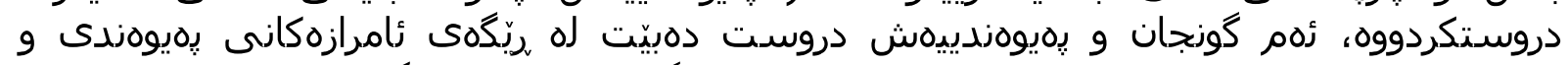

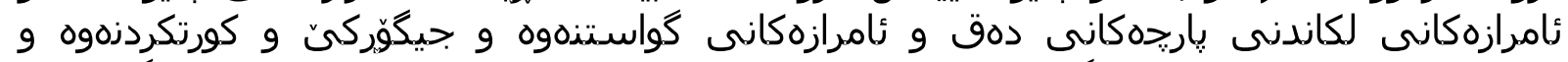

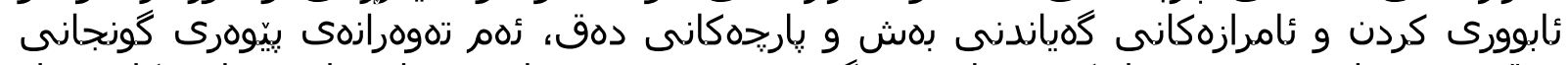

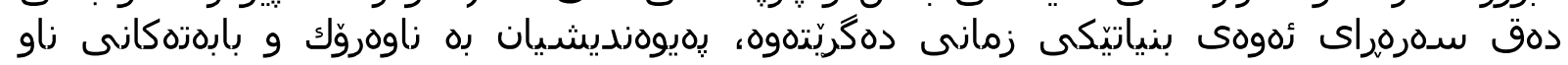

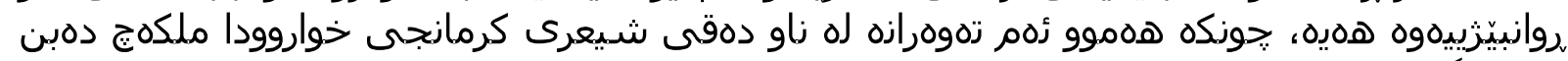

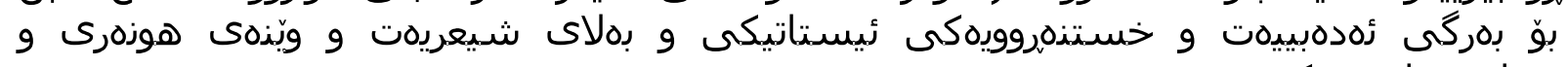

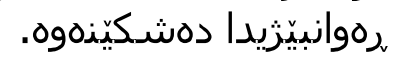




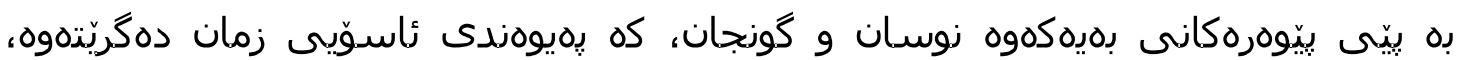

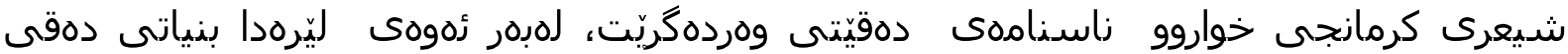

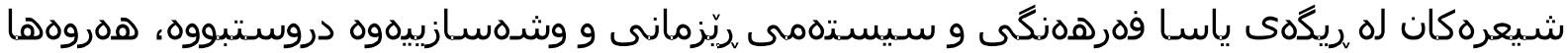

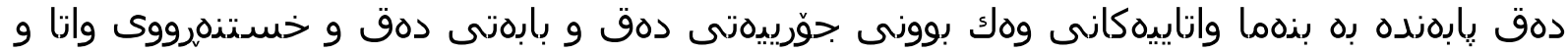

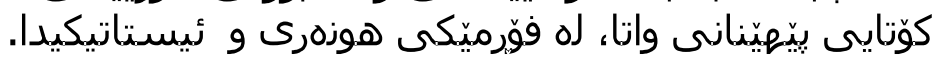

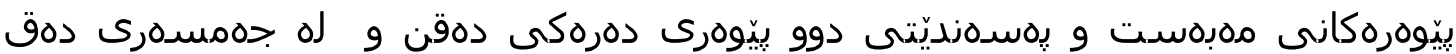

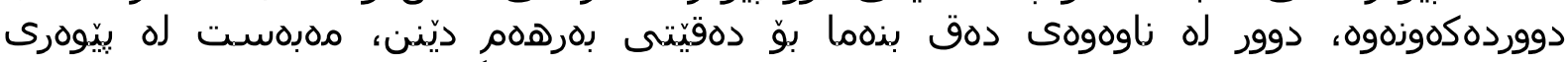

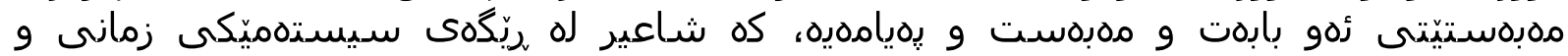

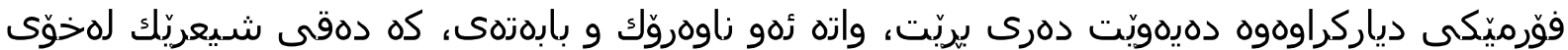

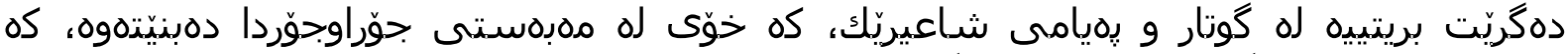

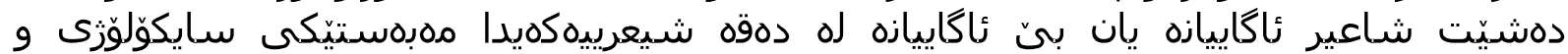

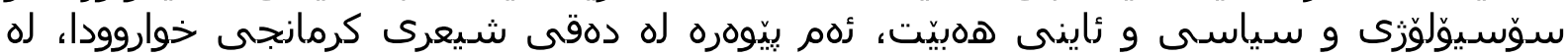

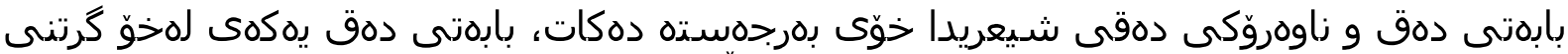

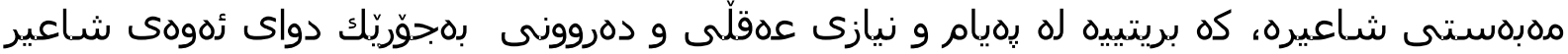

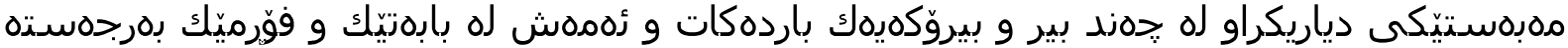

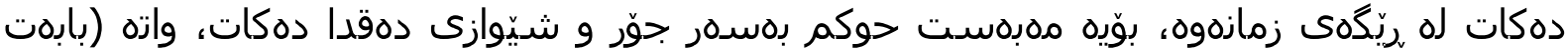

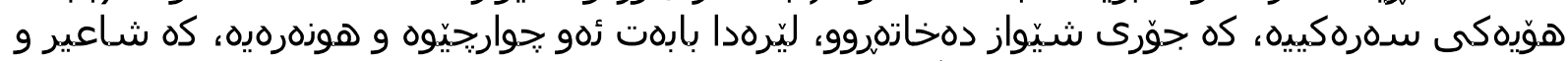

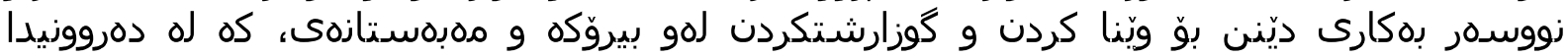

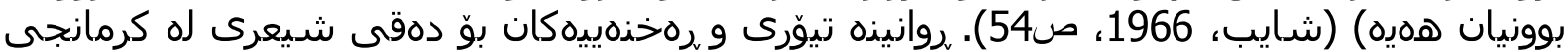

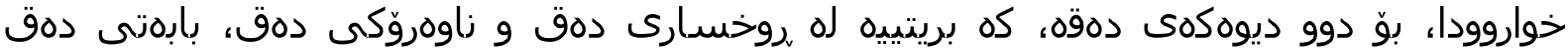

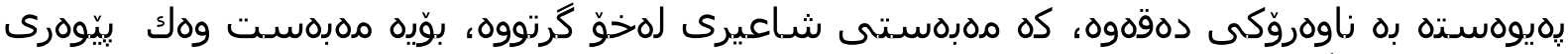

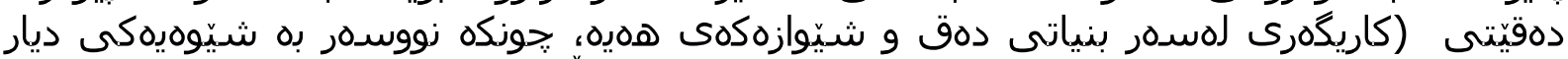

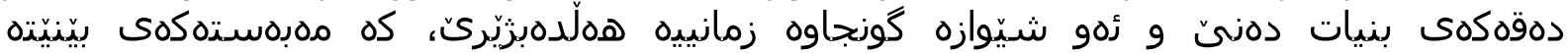

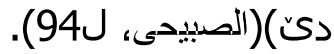

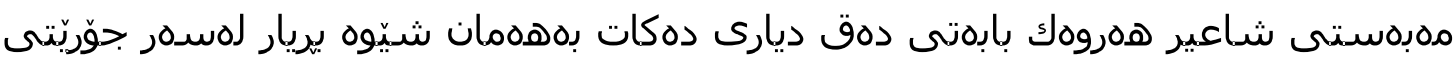

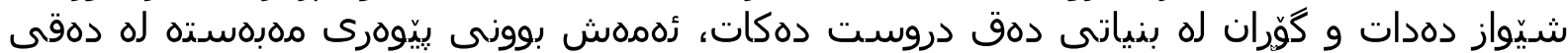

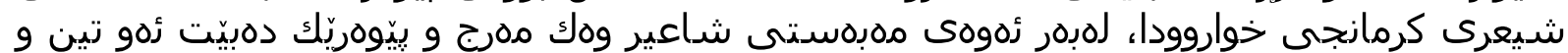

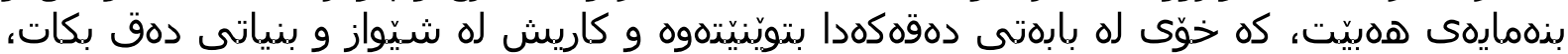

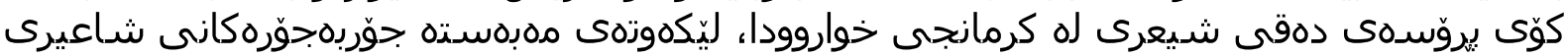

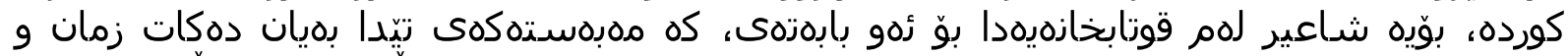

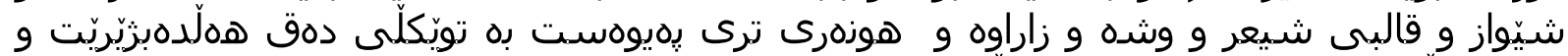

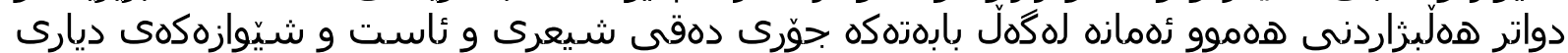

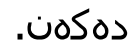

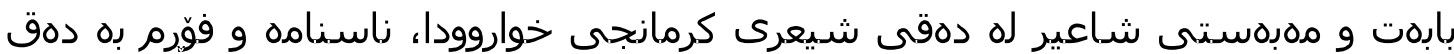

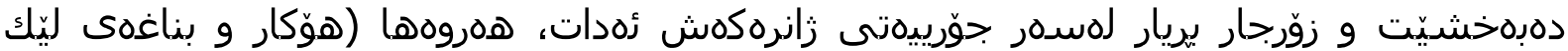

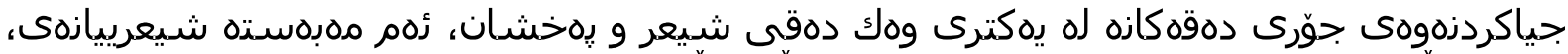

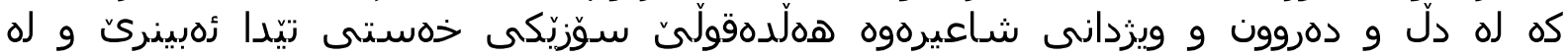

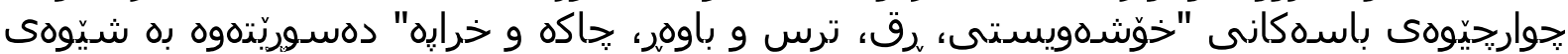

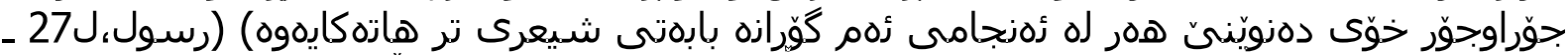

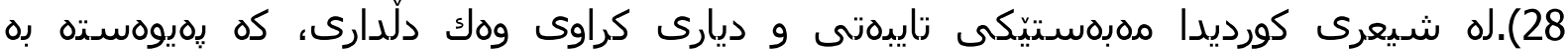

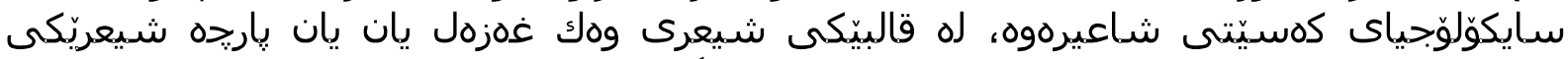

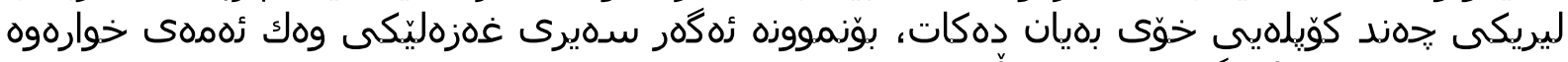

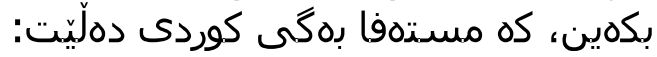

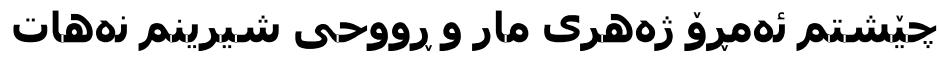


زهخمى كوّنهم هازه زان و مهرههمى برينم زههات

تا دماته

كَوّى يحموكانى ميحنهت دايه بهر خوّى رايفراند

زه لعهبمب بوّ شههسوارى خانهيى زيغم نههات

كهوتمه زاو زهزع و غهم خستميه حالّى غهر غهره

(كوردى)بیى كهس خوّم له هيه لايیى سهداى شينم نههات (كوردى، ديوان، ب1،

(115

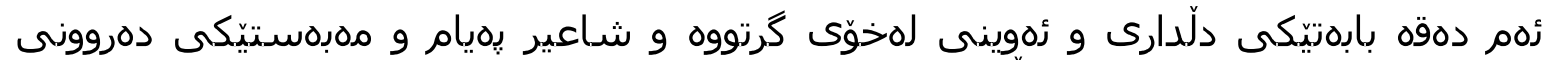

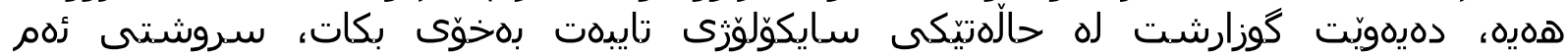

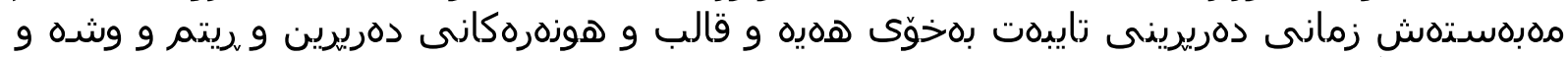

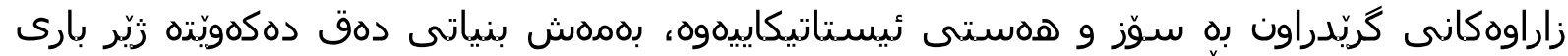

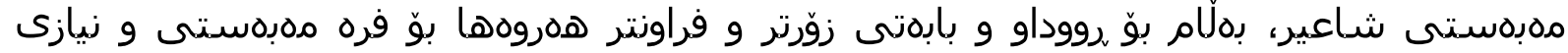

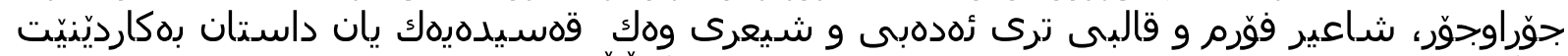

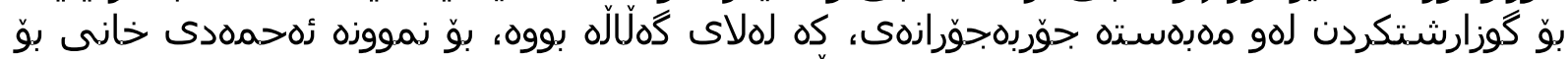

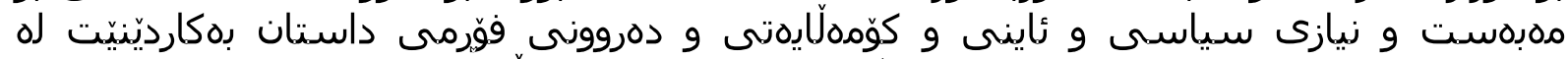

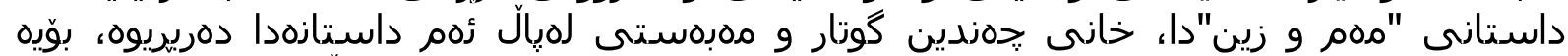

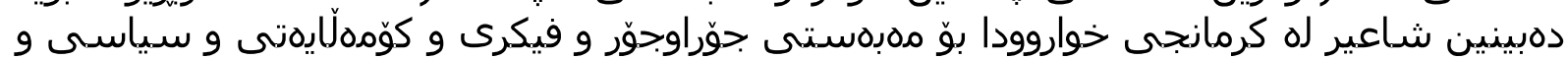

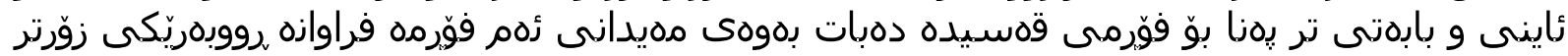

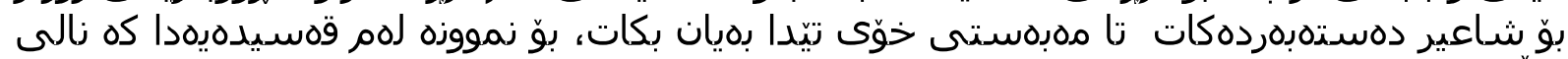

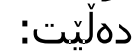

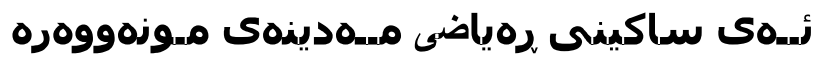 \\ ل...وطفَ بكه، بفهرم...9: مـهدينهى منهو، وهره عهرشى بهرين كـ..0 دائيرهيه، رموضه مهركهزه فــمرشى ز0مسين به عهرصليى طليبه موجهوهمره تا داته

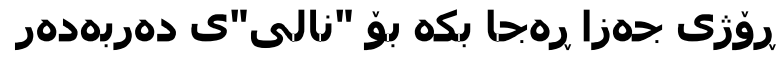

\section{(نالى، ديوان، ل415)}

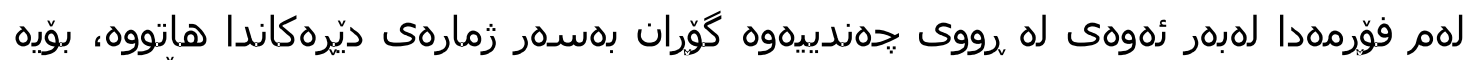

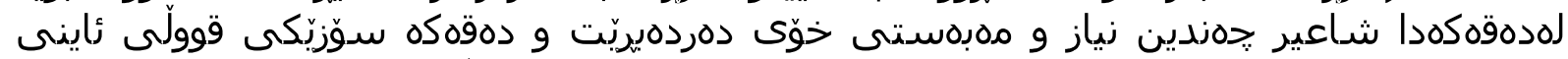

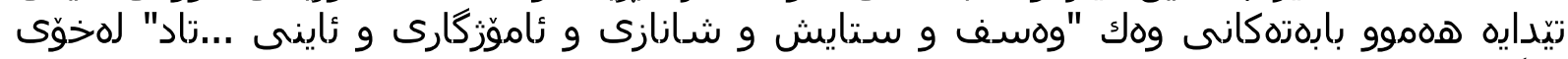

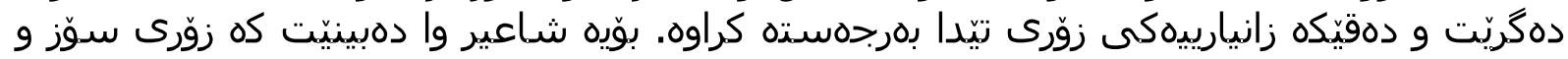

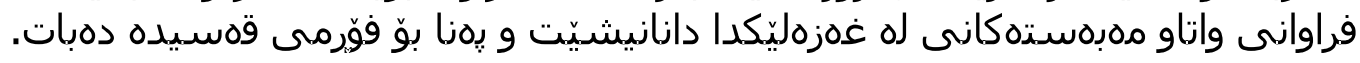

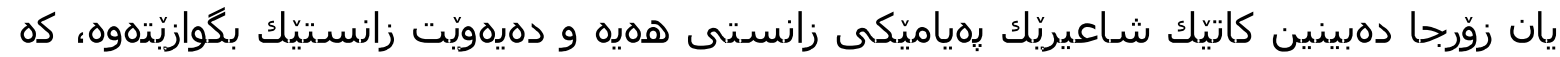

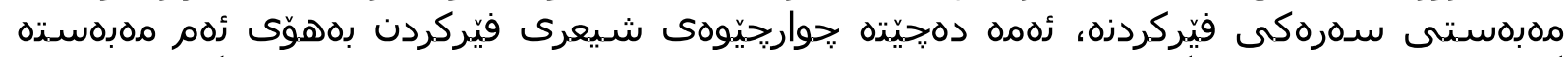

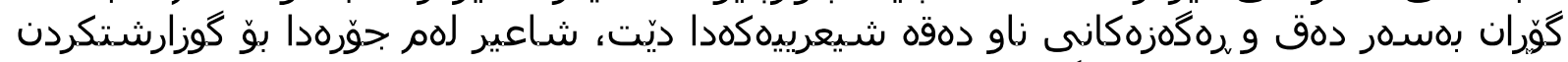

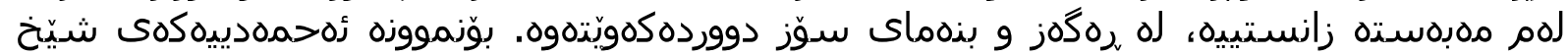

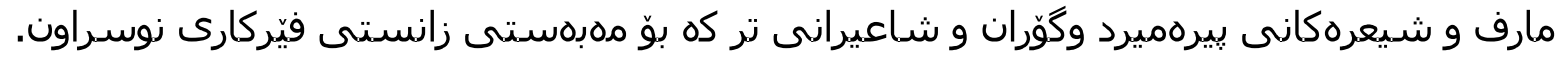




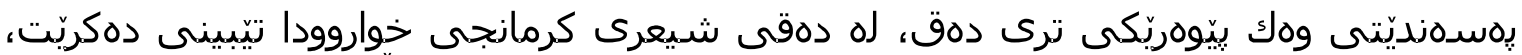

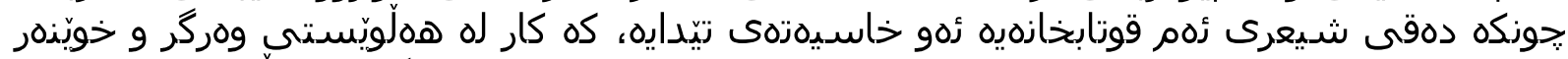

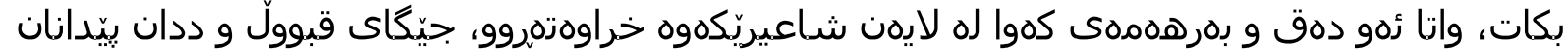

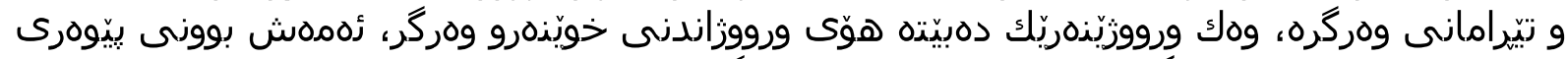

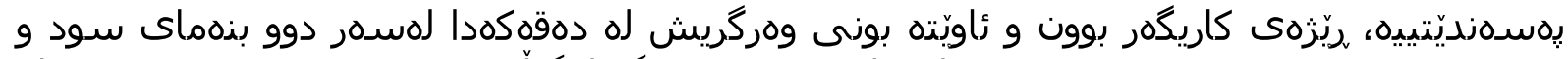

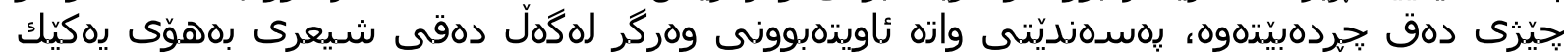

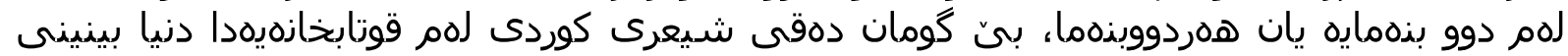

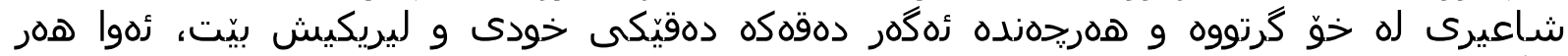

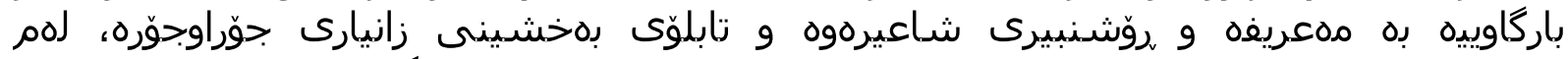

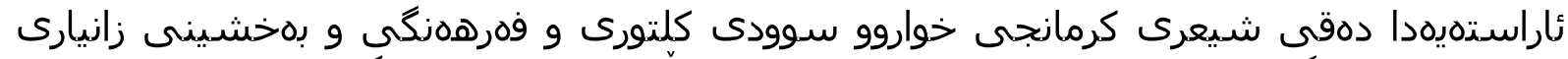

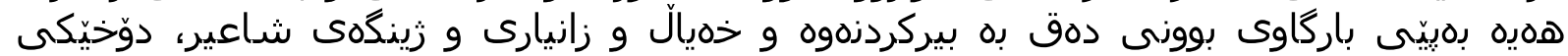

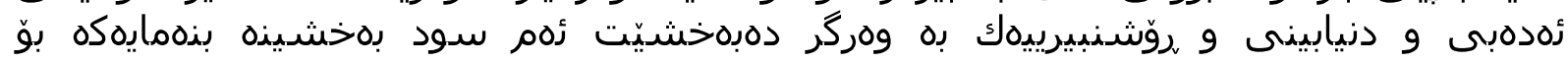

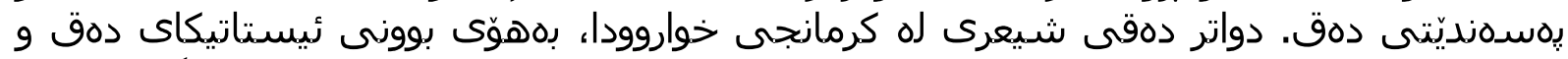

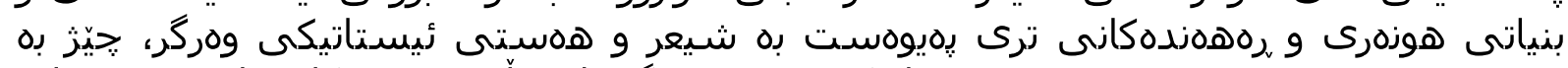

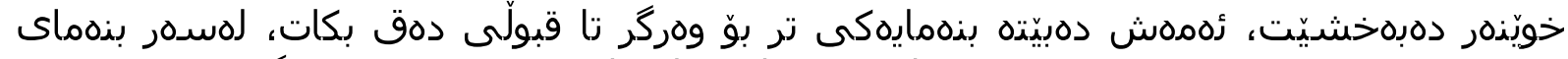

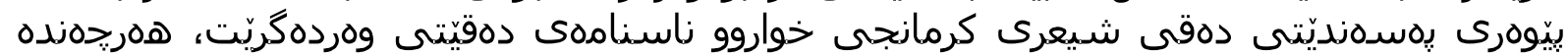

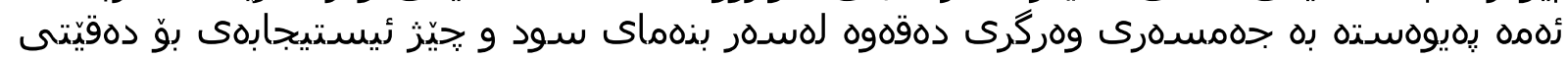
دهق دهبيَت.

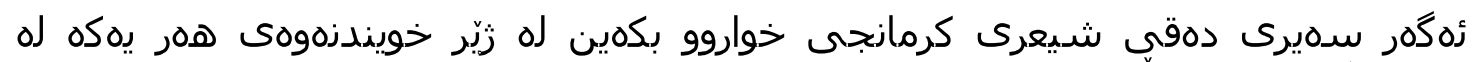

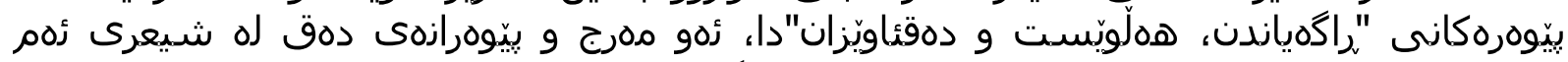

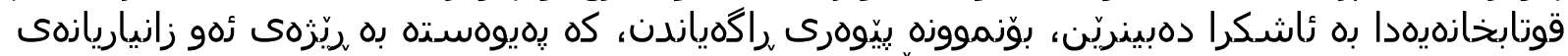

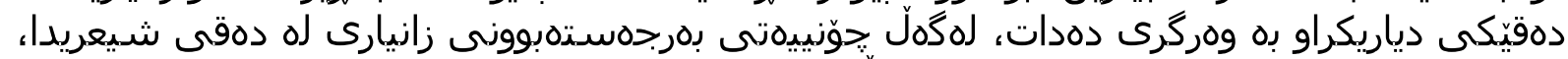

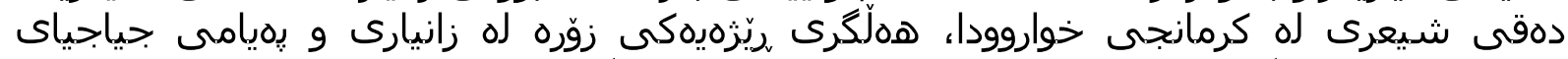

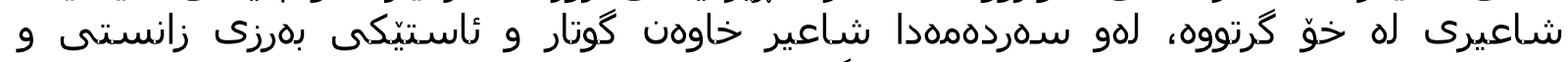

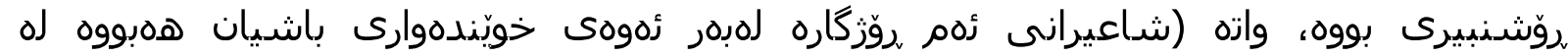

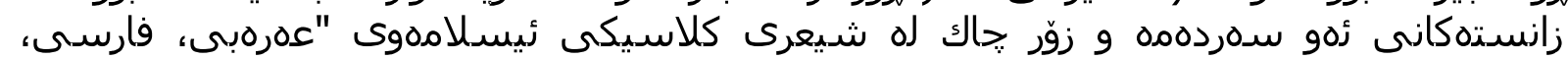

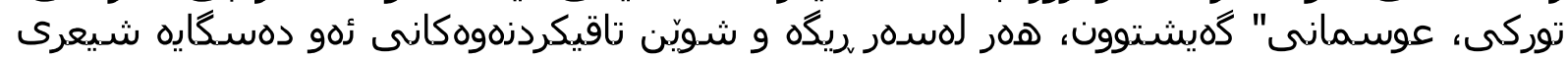

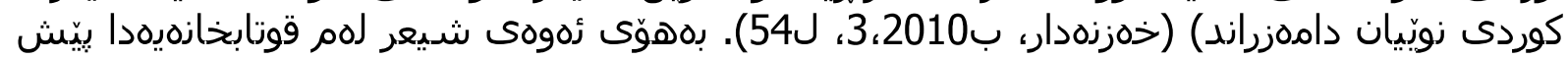

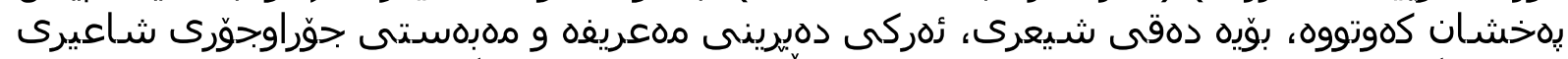

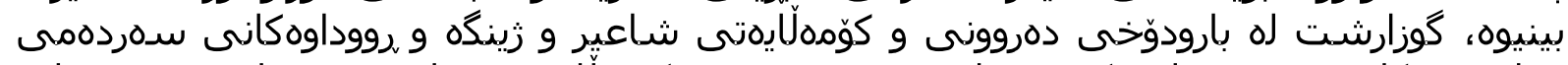

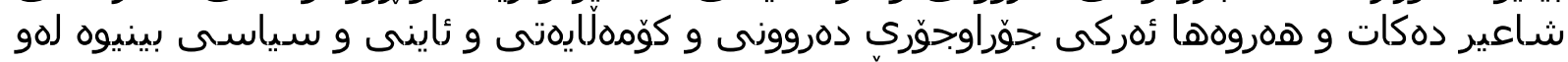

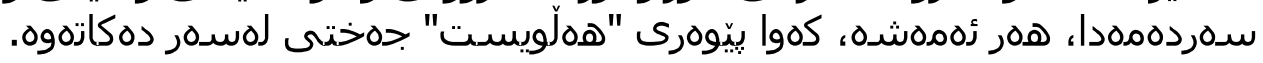

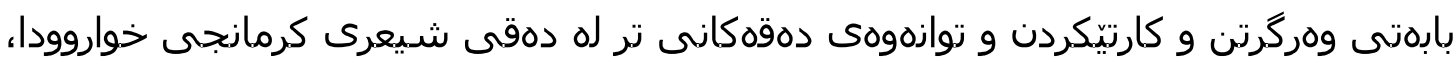

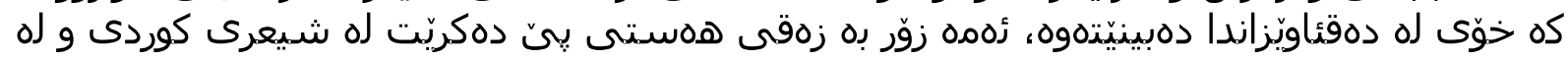

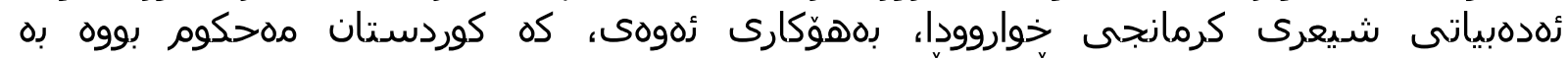

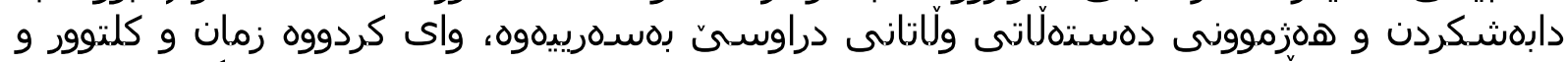

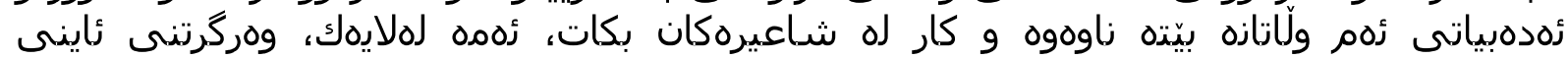
ئيسلاميش له له لايهكى ترهن

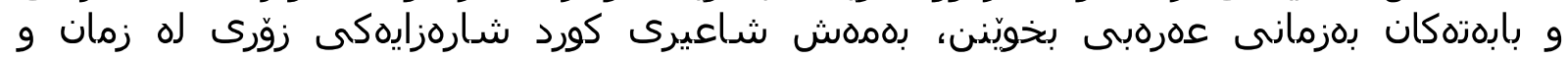

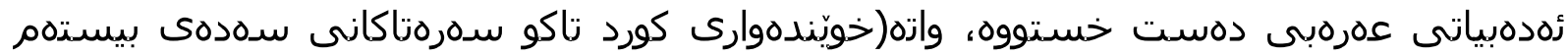

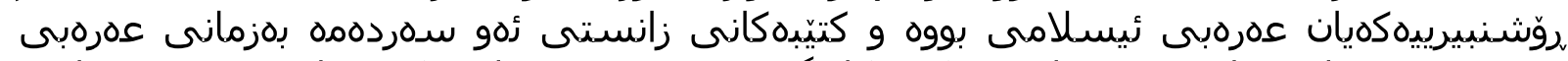

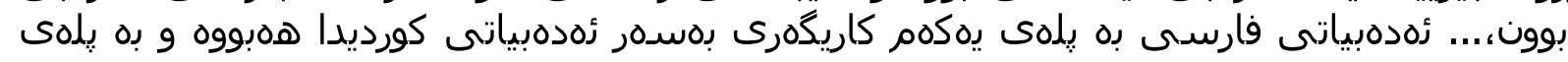

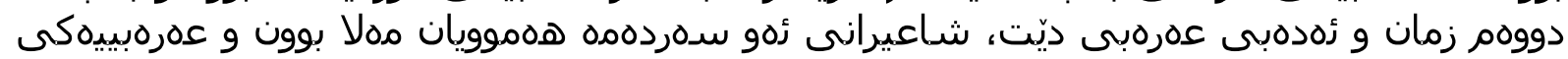

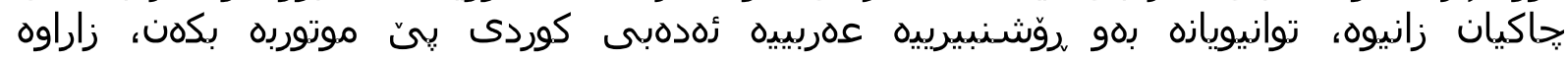

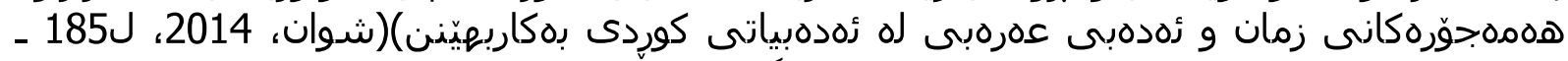

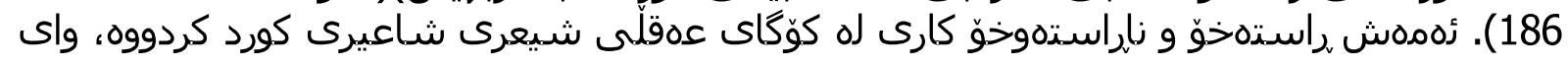




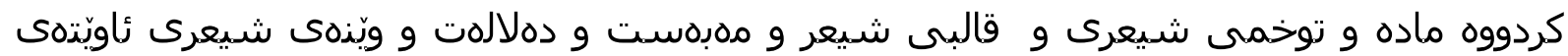

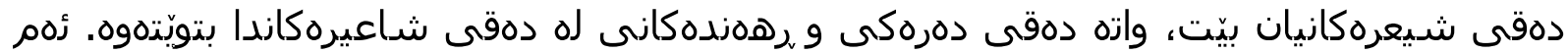

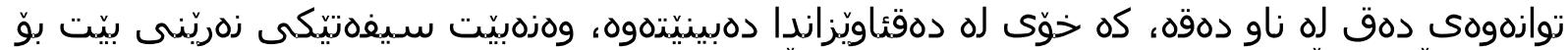

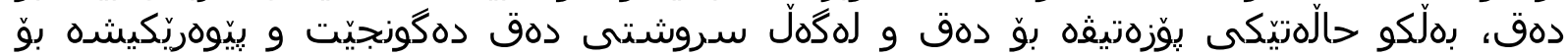
دסقيّتى. دمن.

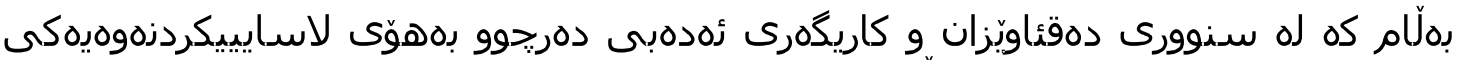

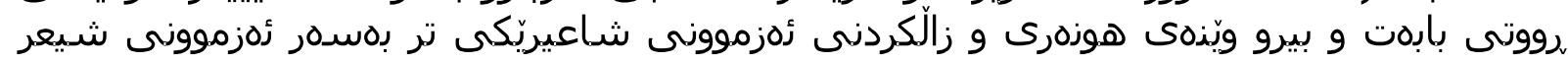

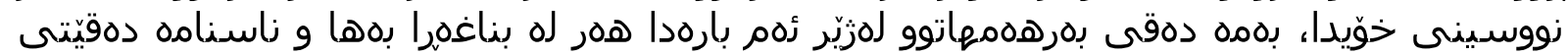

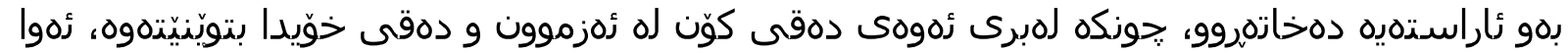

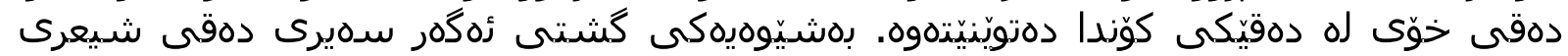

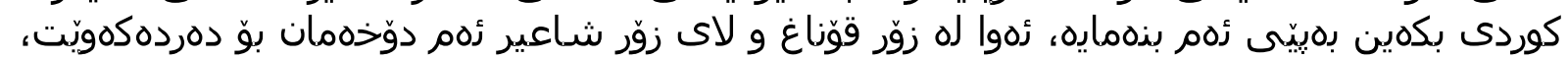
كه بريتيه له به توانهوهى بهين دهو

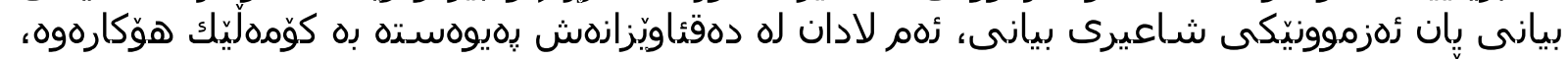

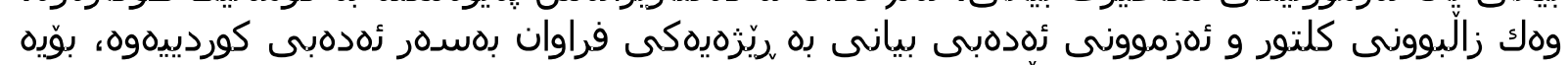

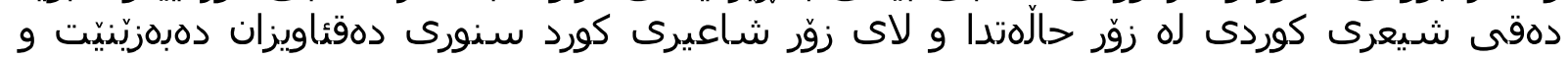

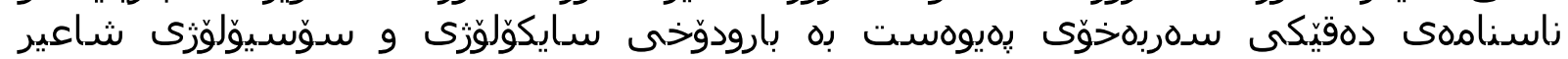
وهرناگرِّت.

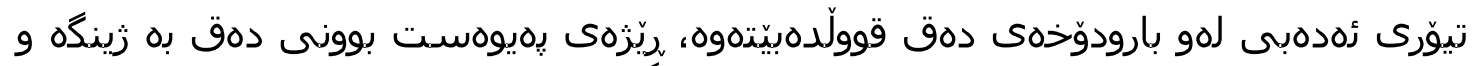

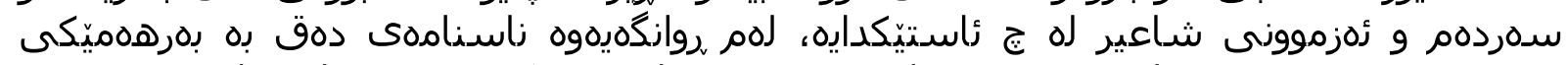

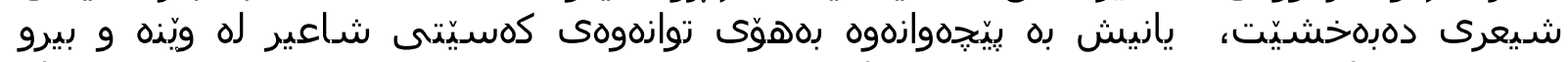

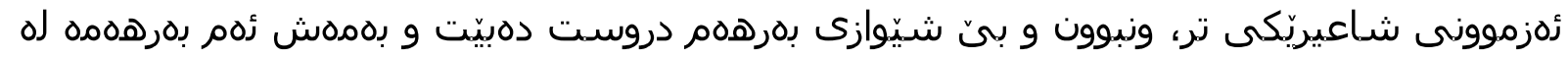

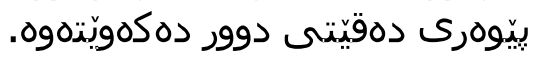

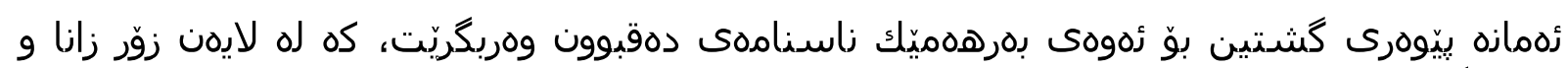

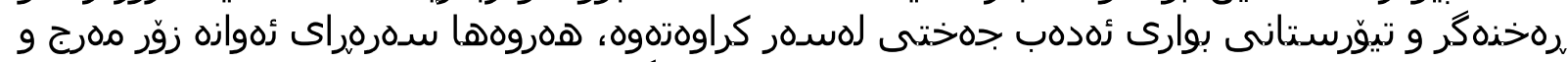

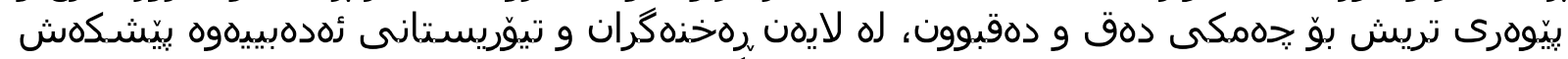

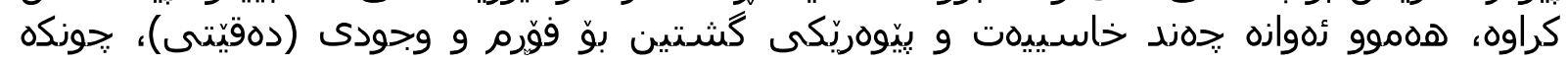

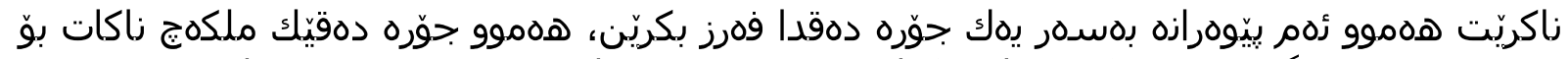

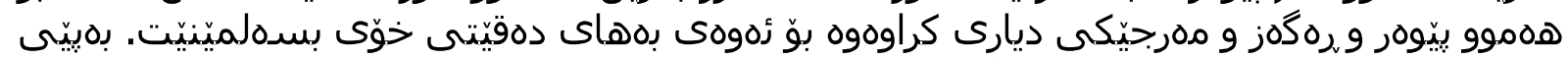

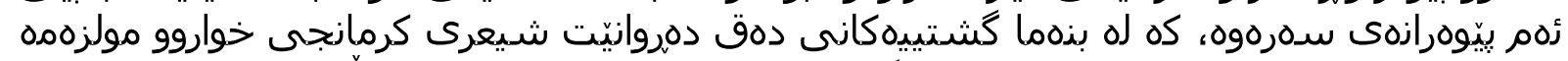

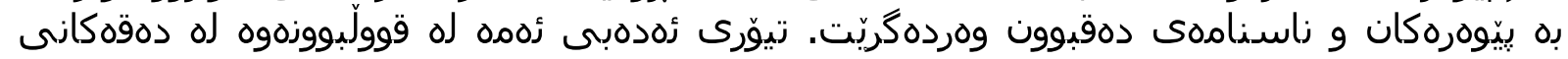

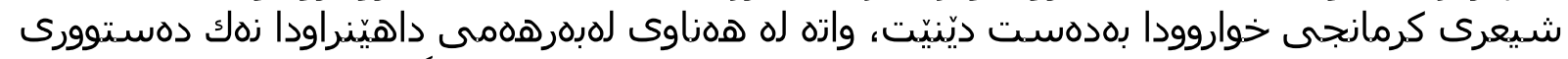

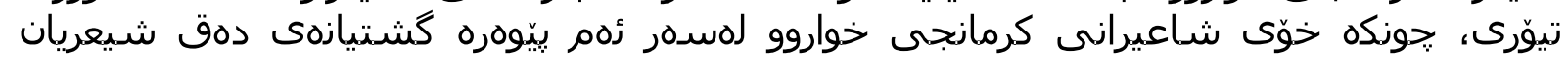

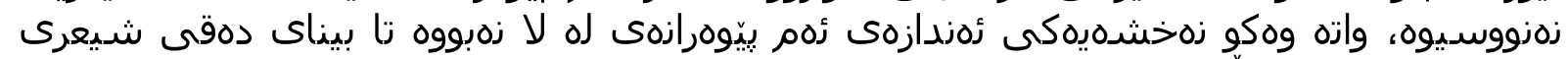

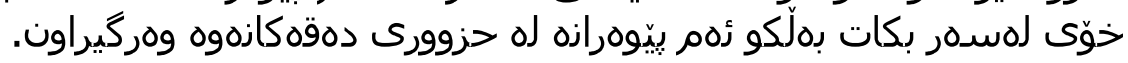

شيعرى كرمانجى خواروو له زبّر روّشنايى بِيِوهره تايِهتييهكانى دهقيّتى

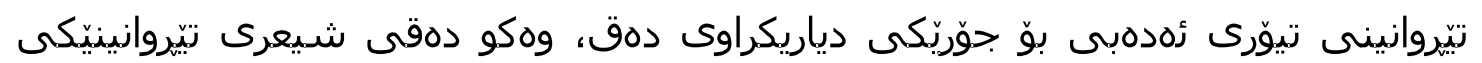

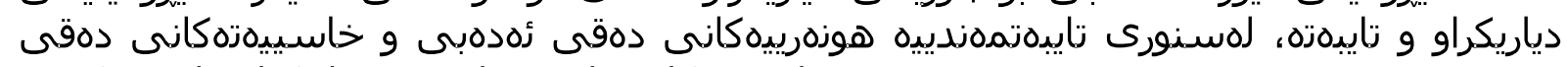

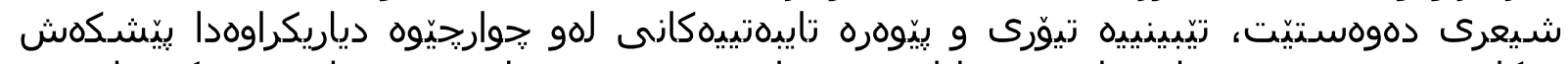

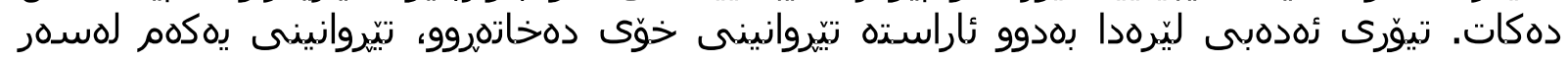

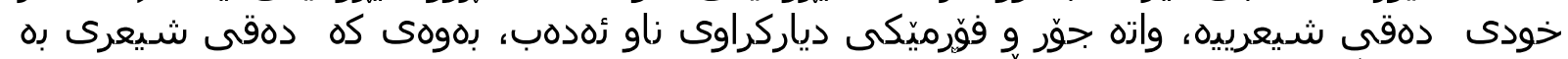

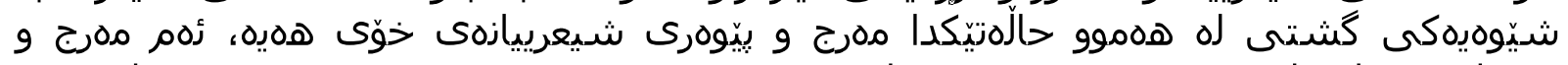

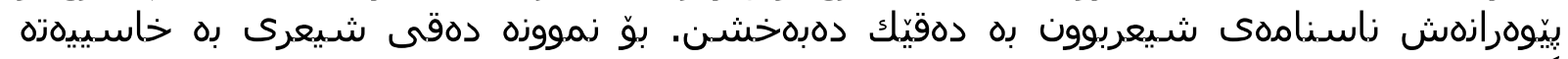

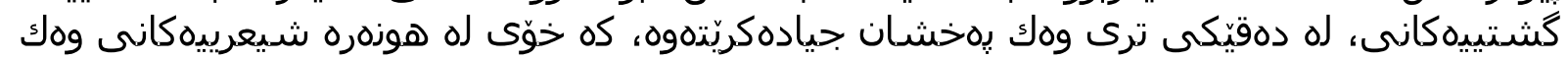

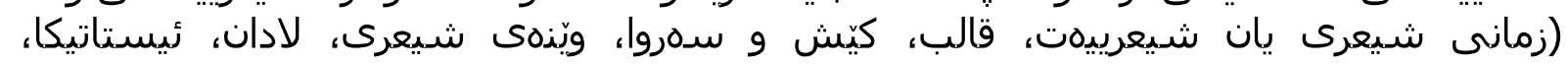




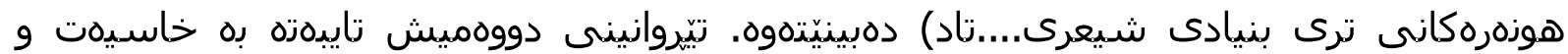

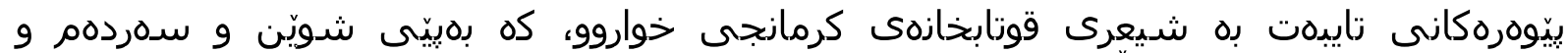

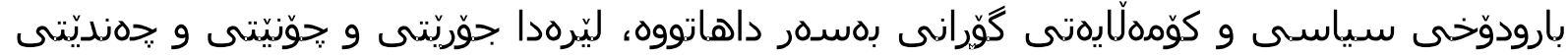

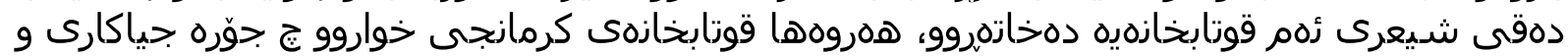

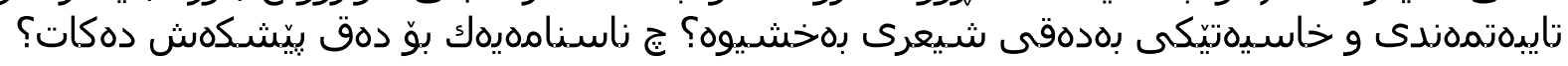

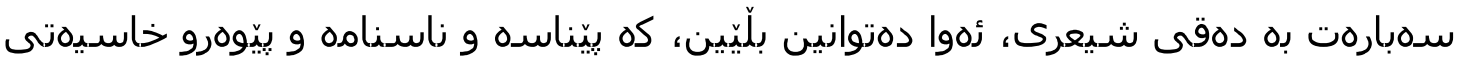

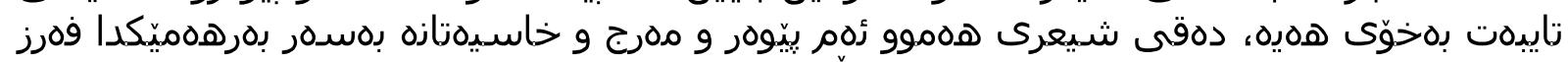

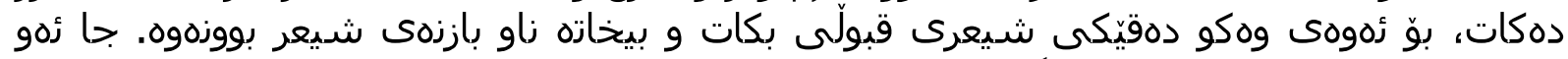

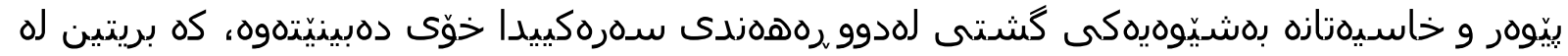

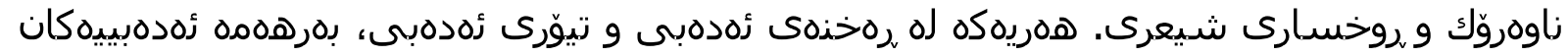

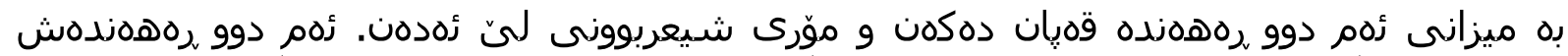

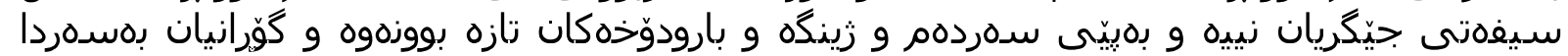
ديّت.

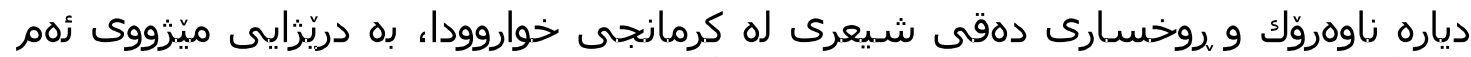

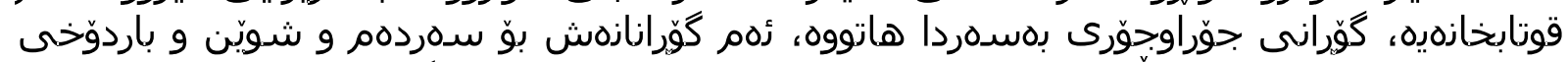

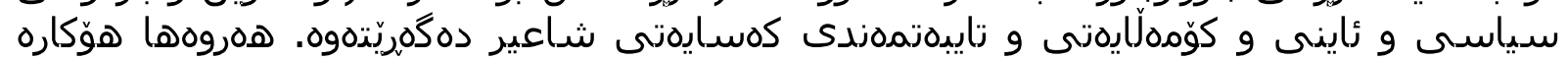

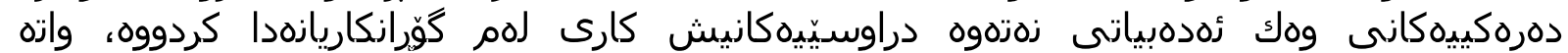

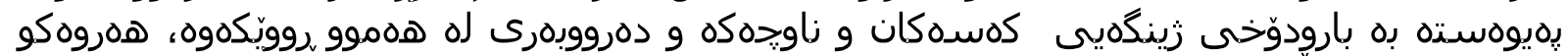

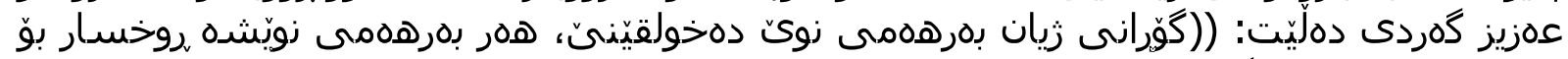

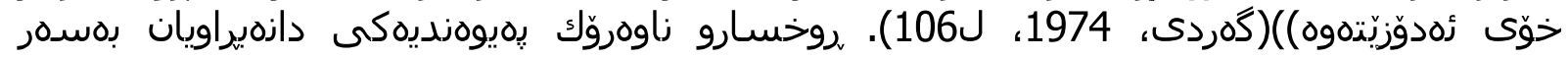

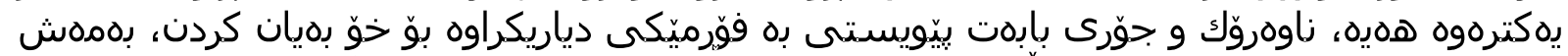

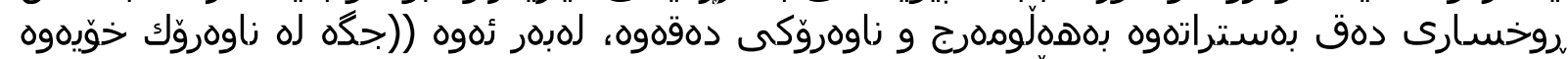

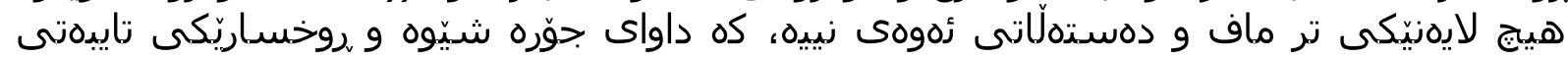

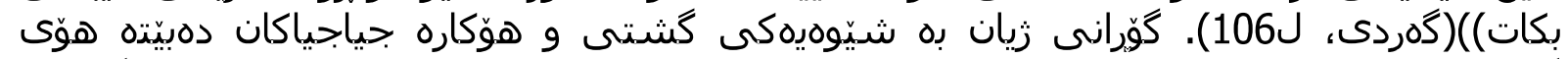

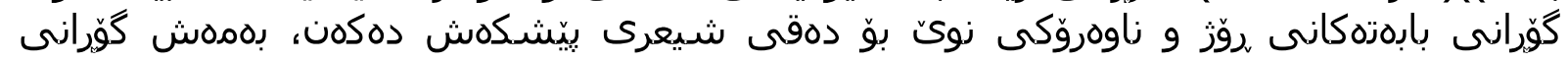
روخسارى دهوقى شـيعر ديّته كايهوه.

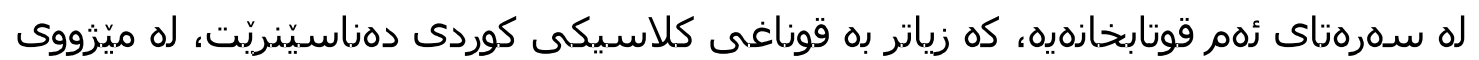

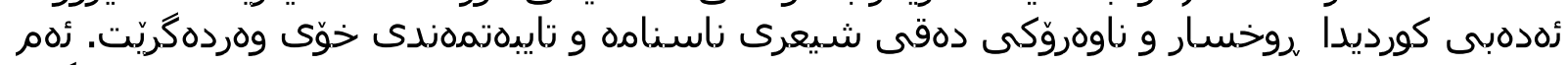

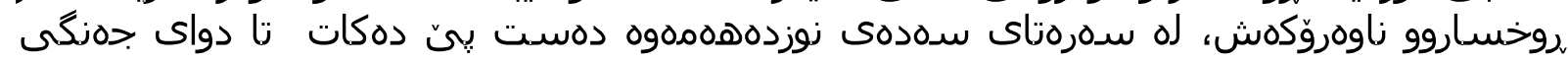

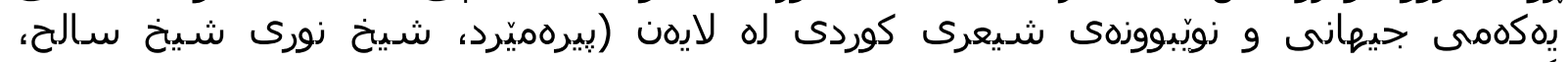

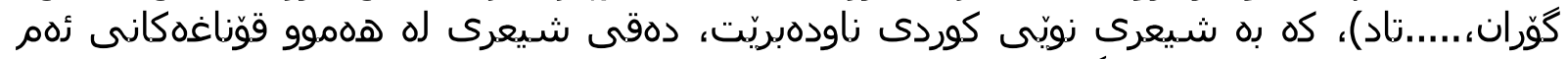

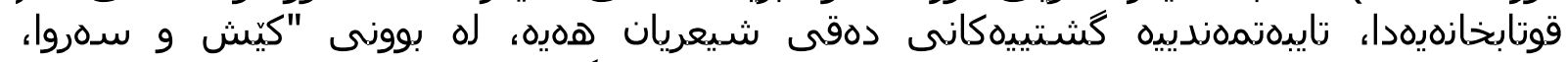

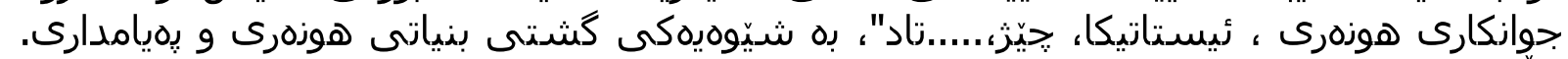

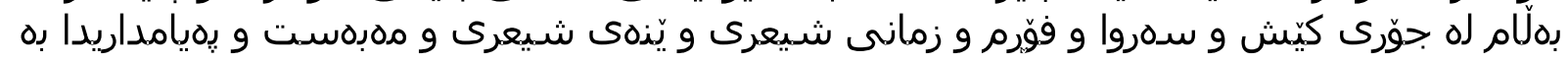

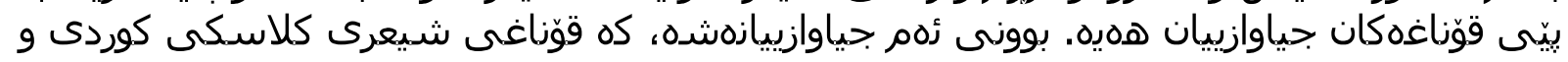

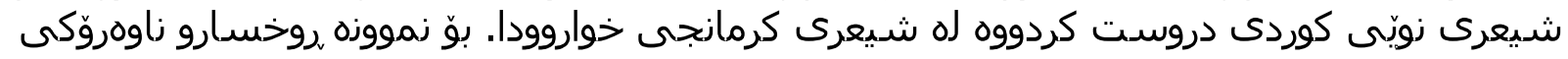

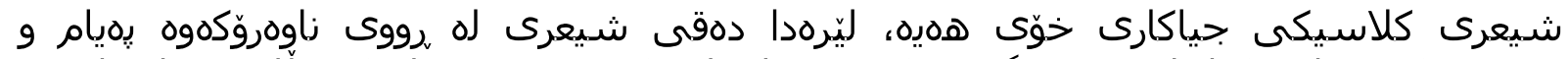

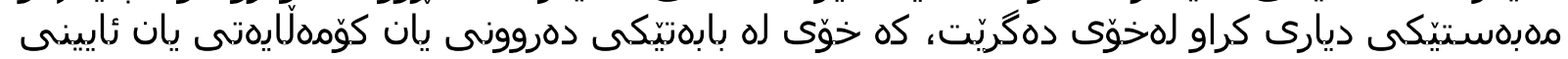

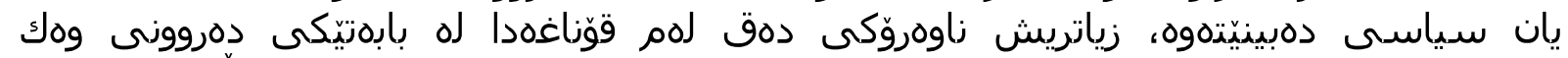

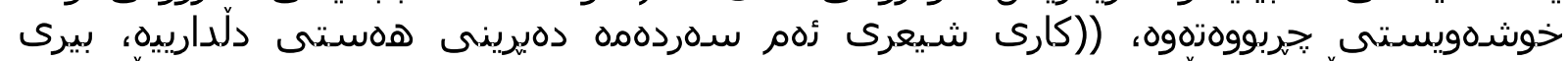

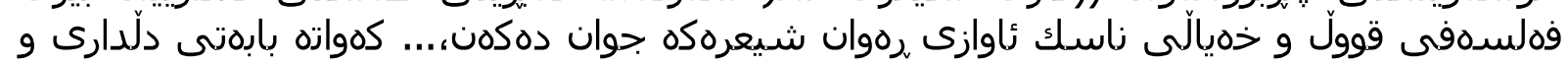

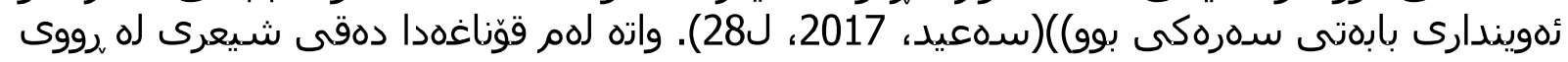

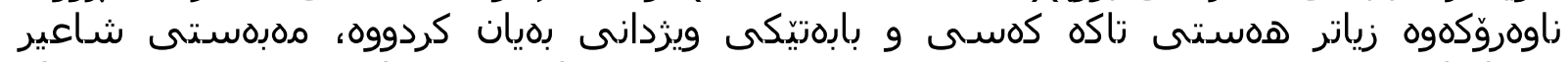

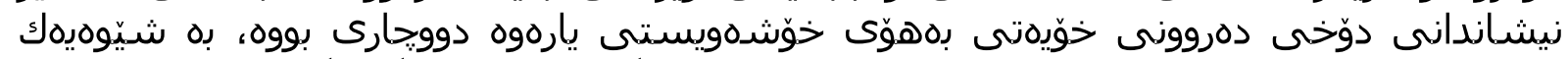

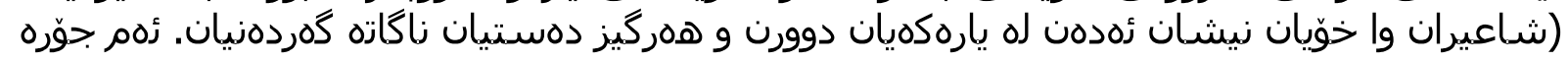




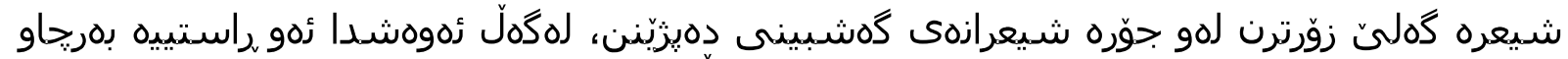

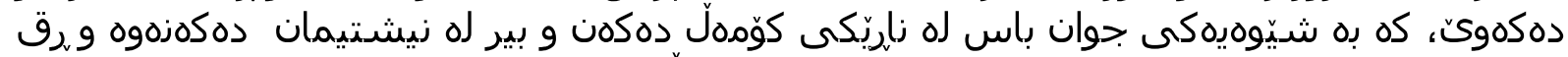

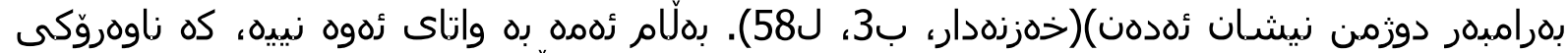

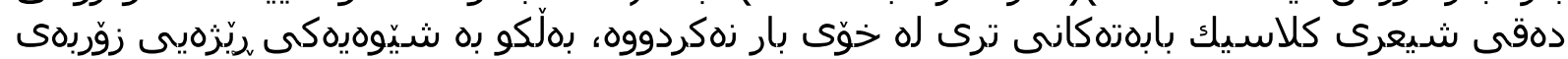

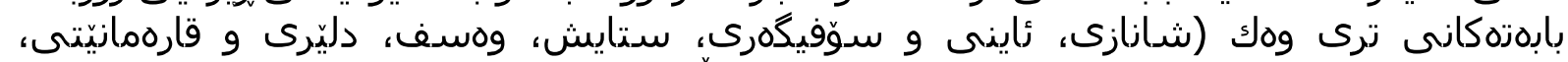

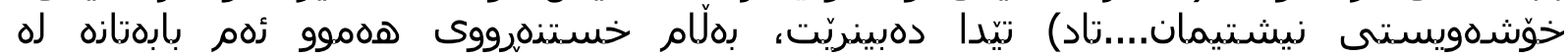

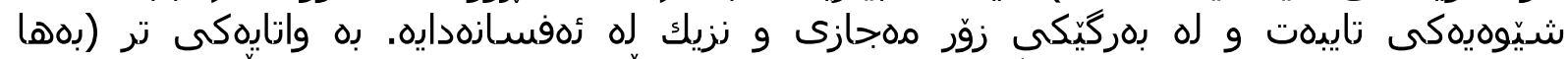

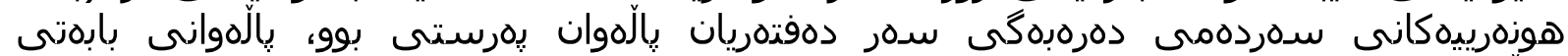

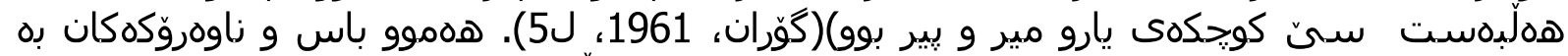

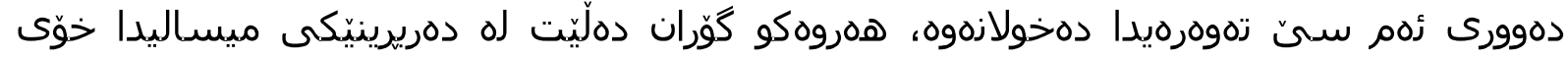

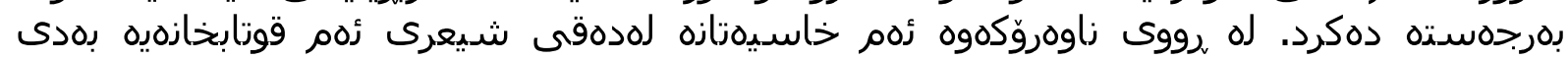
دסكربن.

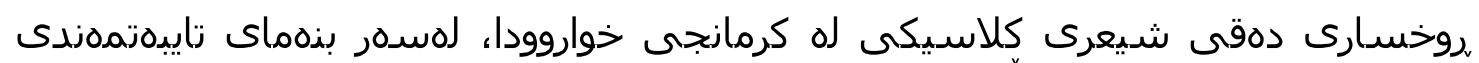

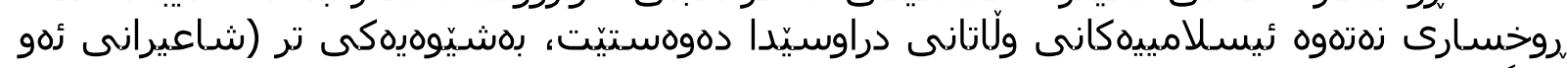

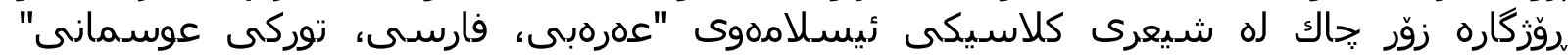

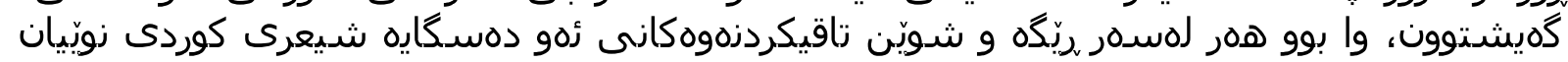

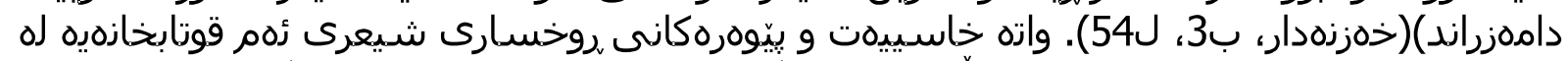

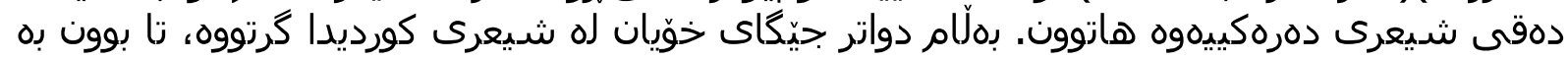

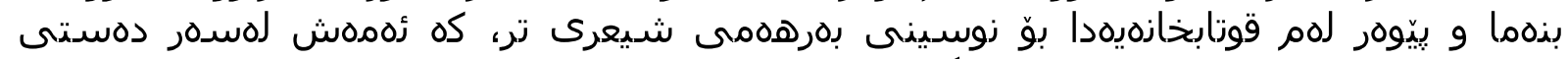

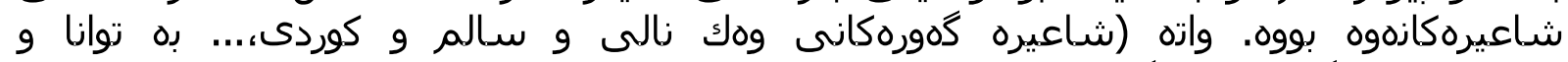

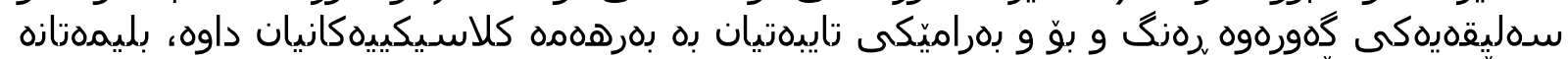

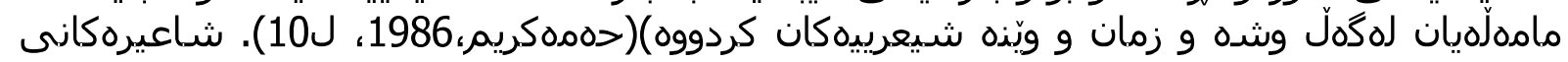

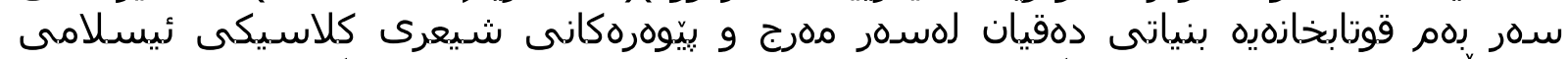

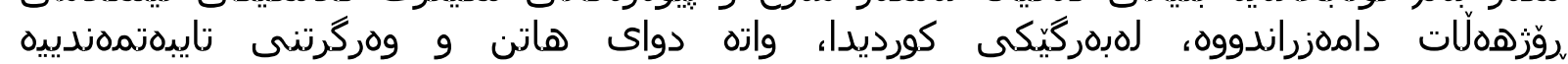

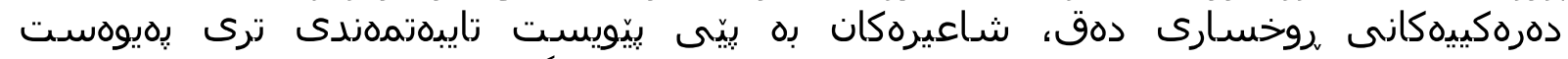

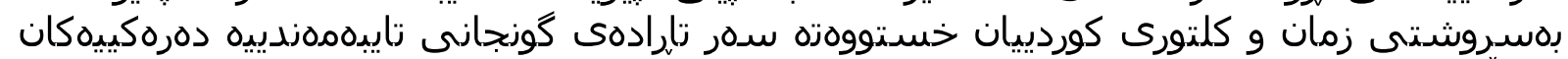

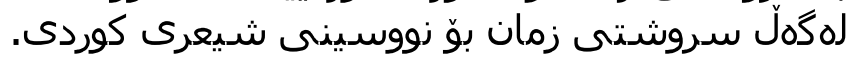

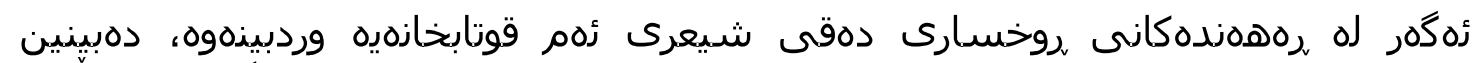

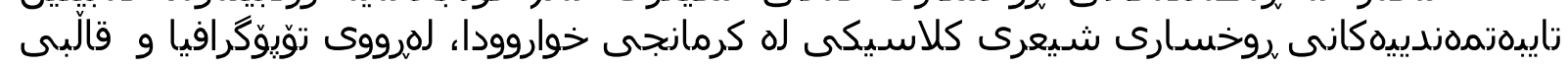

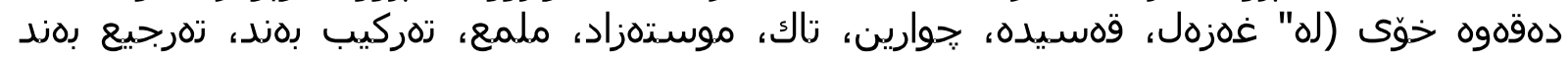

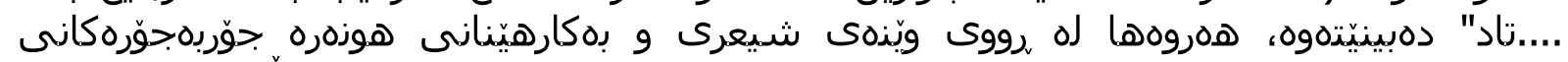

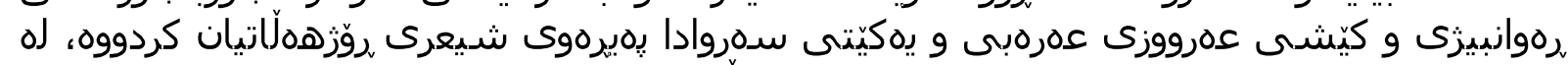

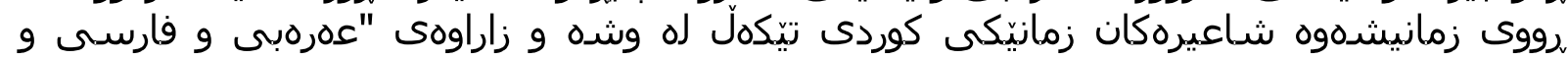

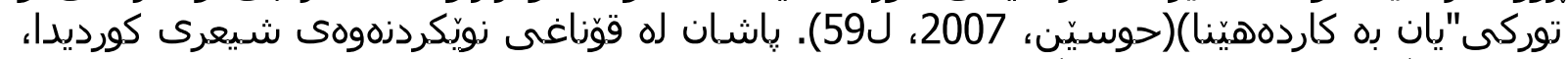

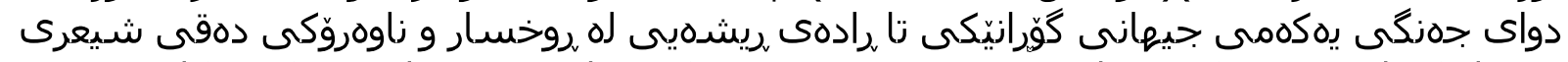

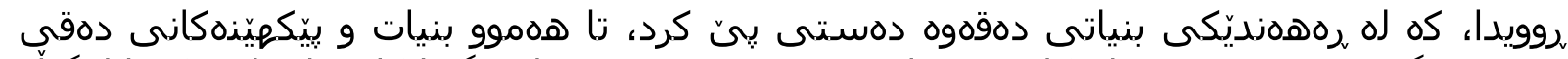

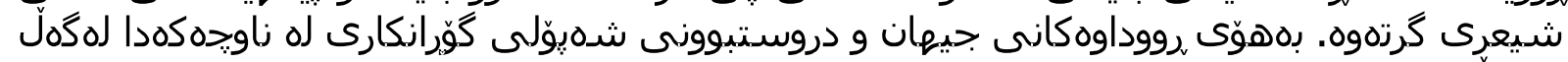

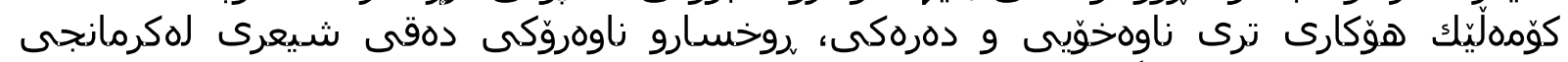

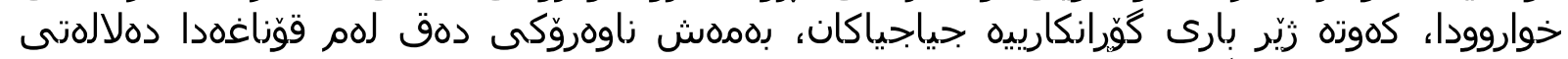

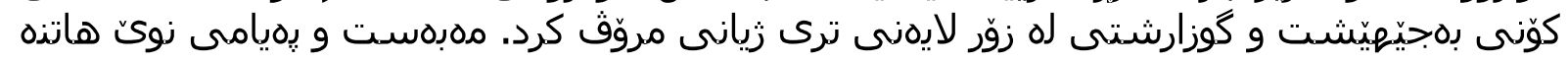

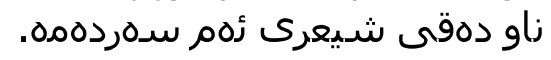

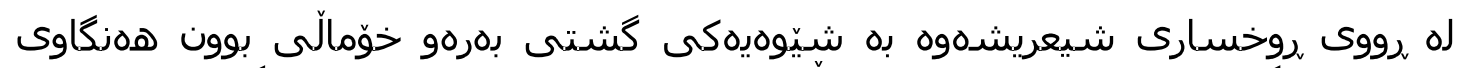

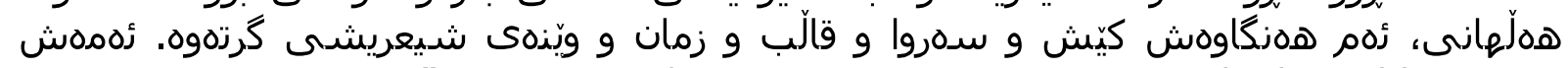

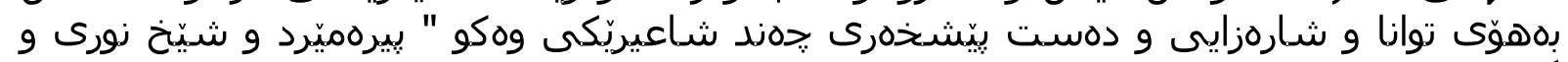

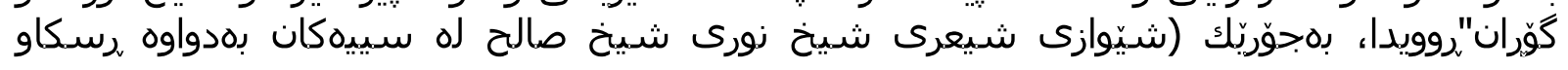

International Journal of Kurdish Studies Vol.5/1 ( January 2019) 


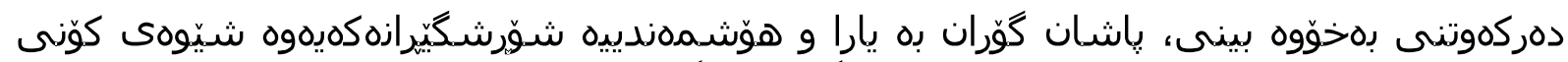

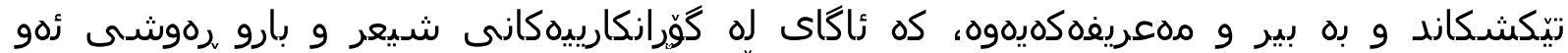

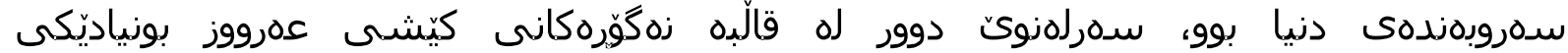

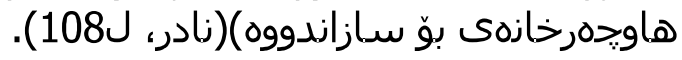

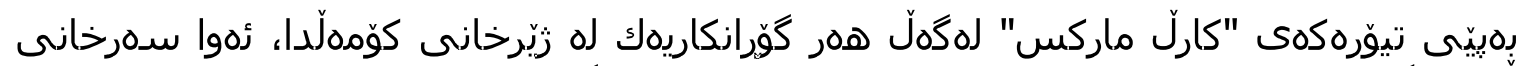

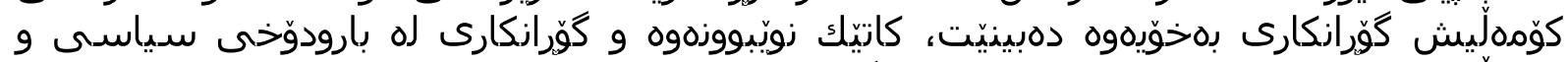

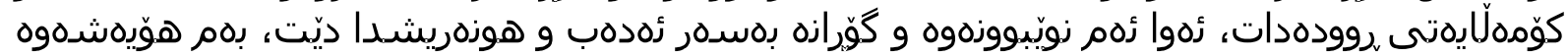

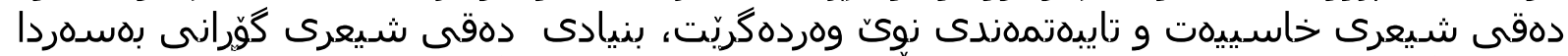

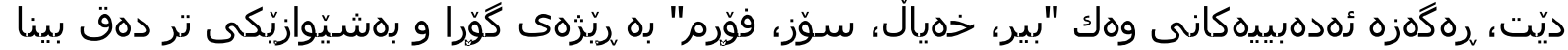

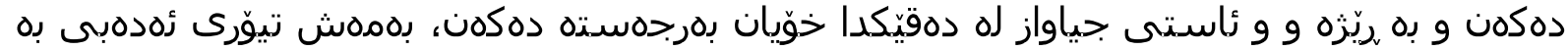

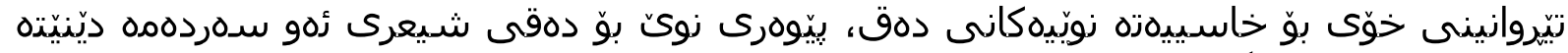

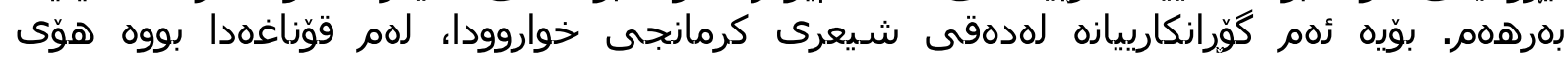

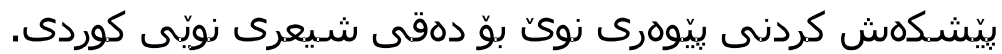

زهزنجامدكان

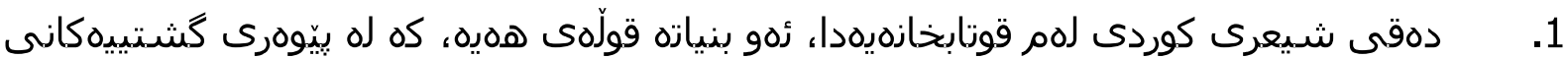

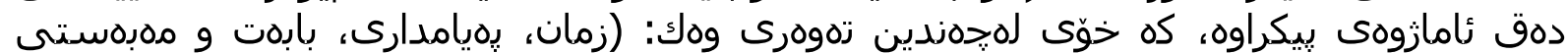

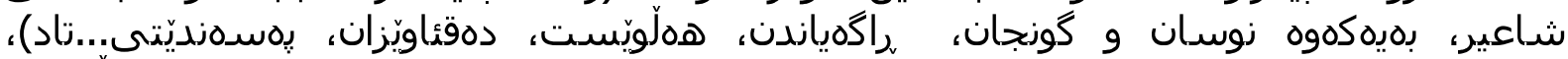

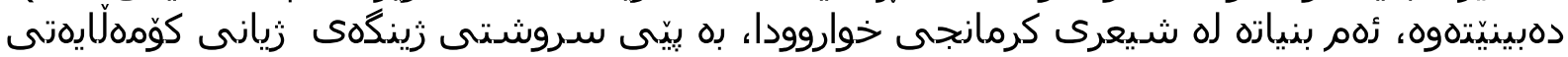

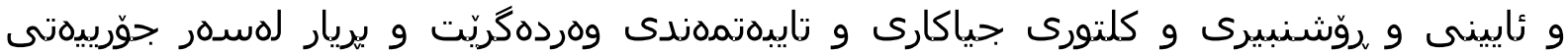
ثانره كهش زٔهدات.

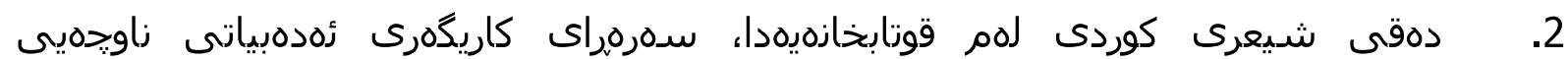

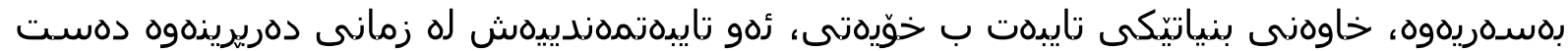

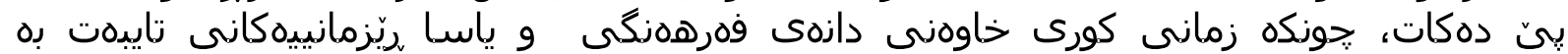

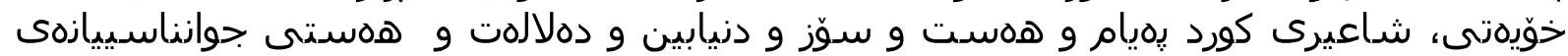

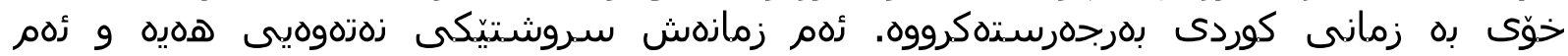

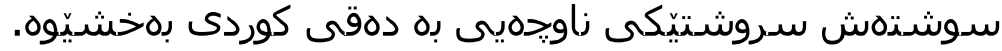

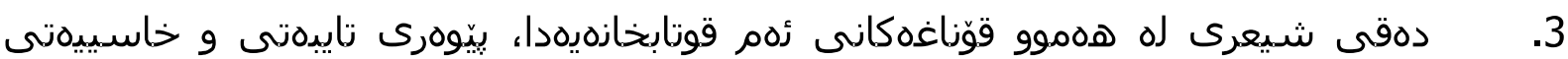

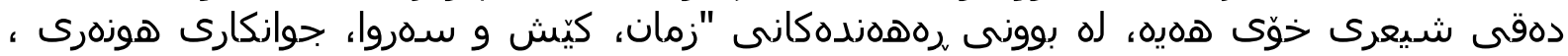

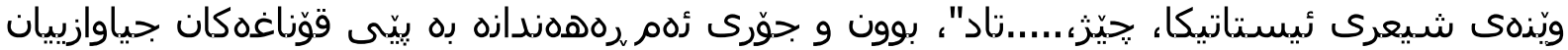

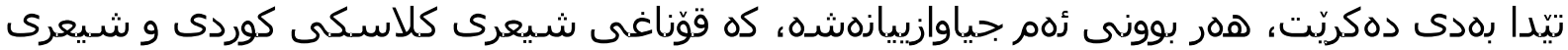

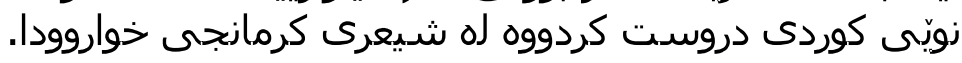

4. روخسارى دهقى شيعرى كلاسيكى له كرمانجى خواروودا، لهسهر بذهماى تايبهتمهندى

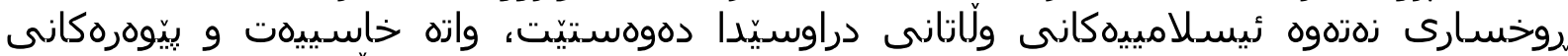

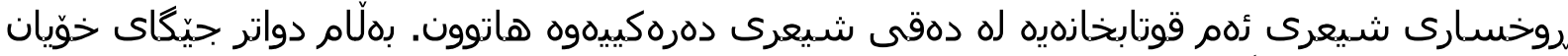

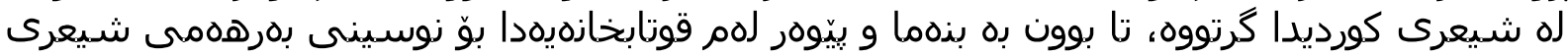

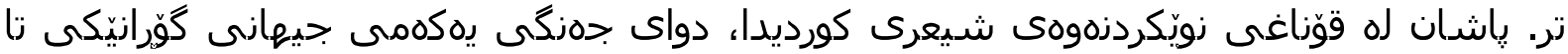

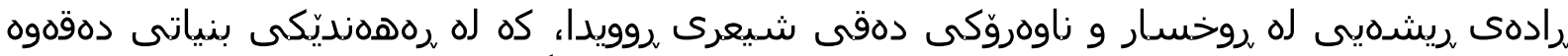

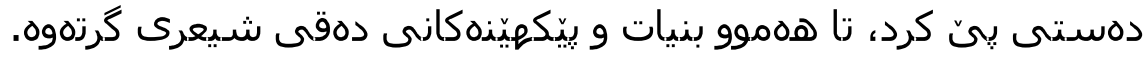

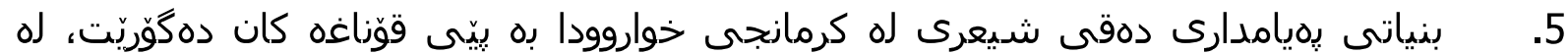

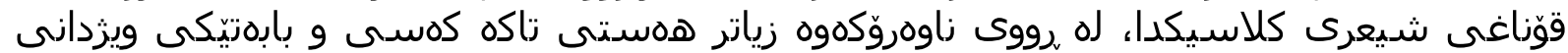

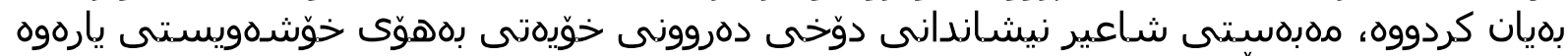

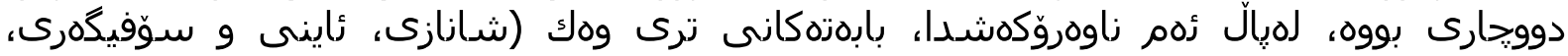




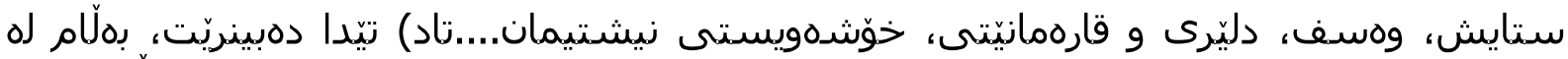

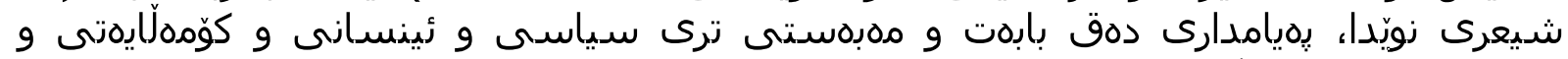

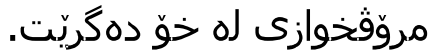

\author{
سهر:باوهكان \\ يكهم ـ به زمانى كوردى
}

1. Salkie, Rafael Text and Discourse Analysis

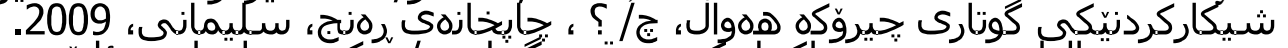

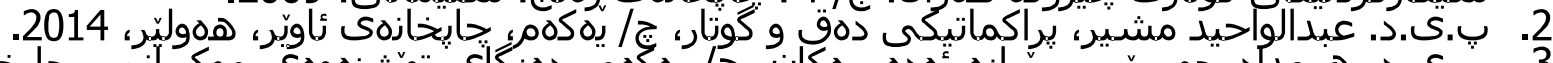

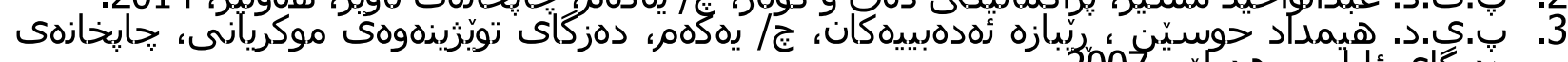

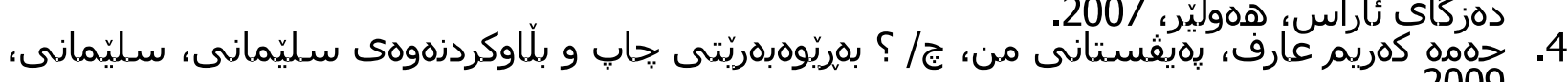

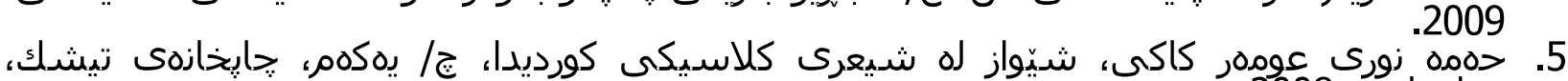

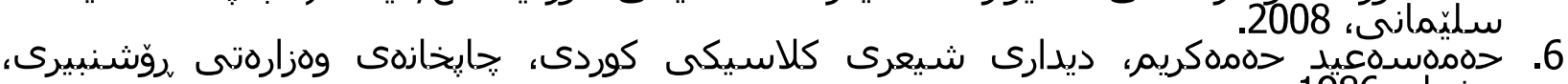

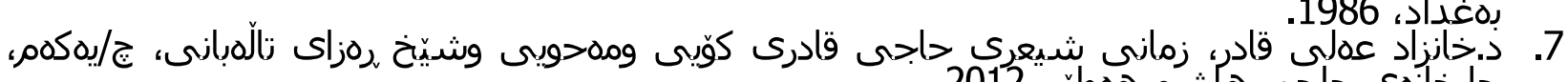

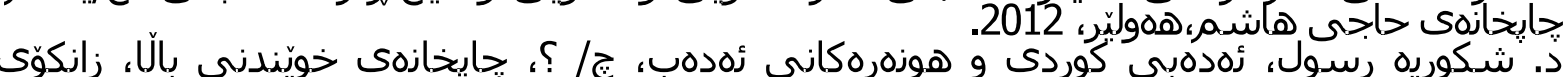

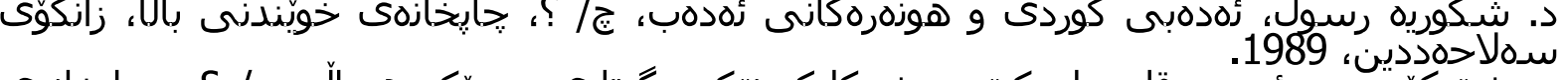

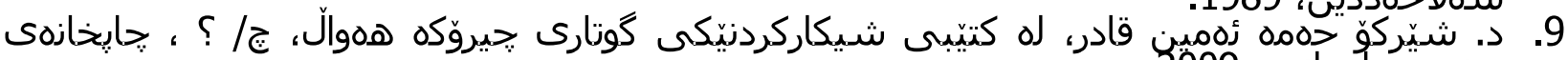

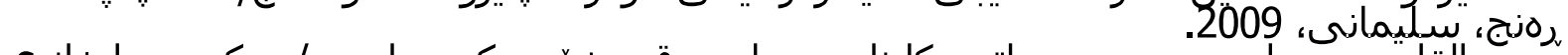

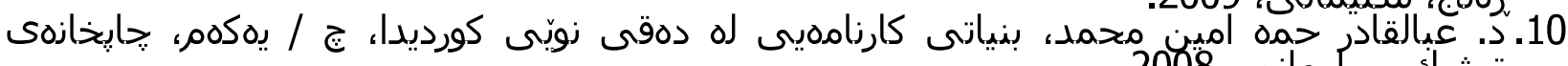

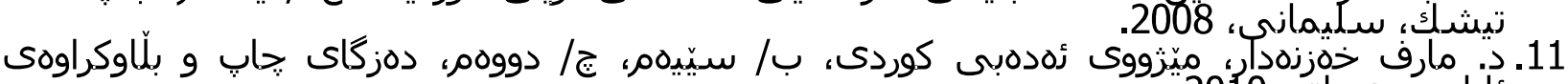

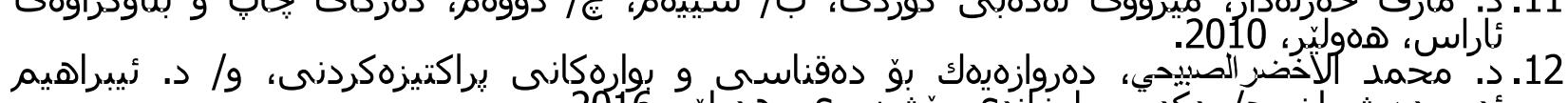

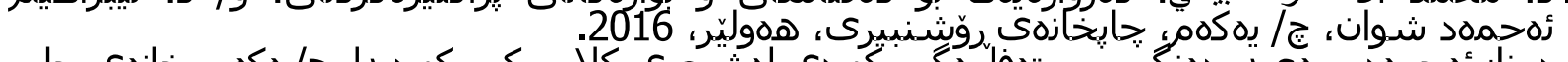

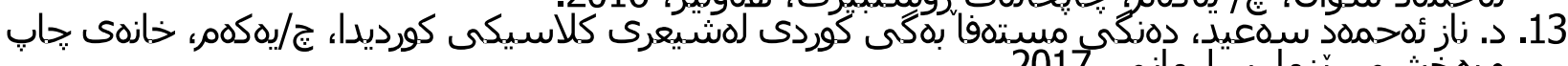

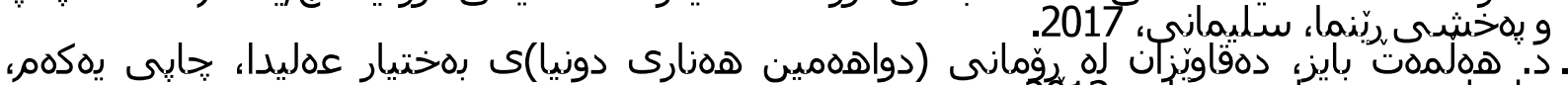

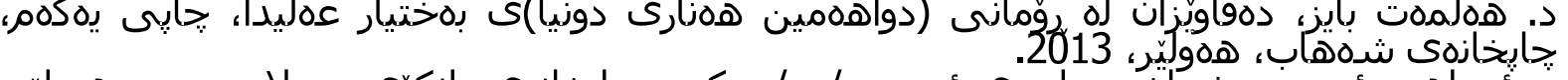

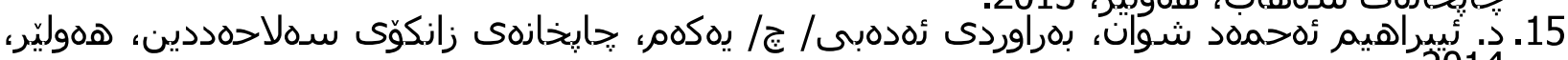

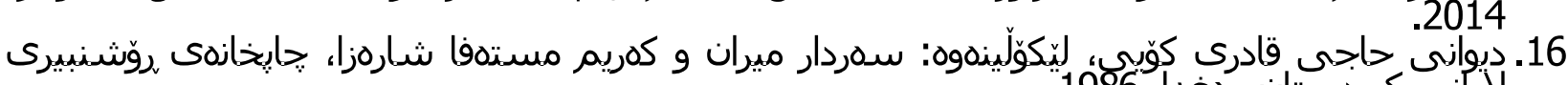

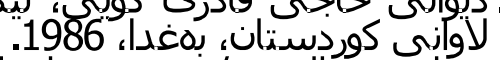

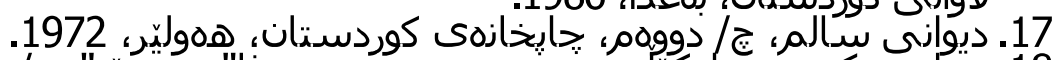

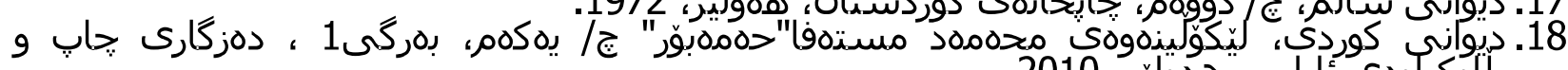

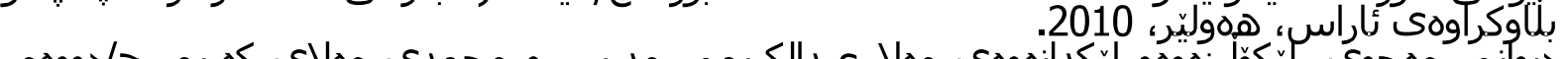

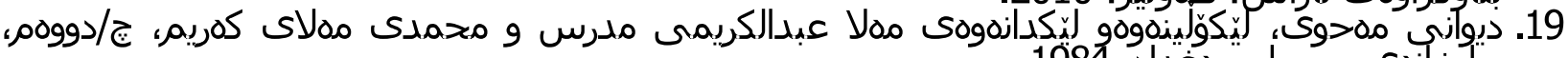

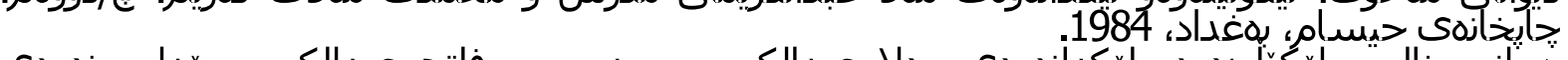

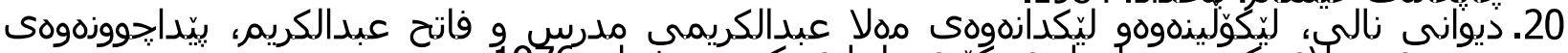

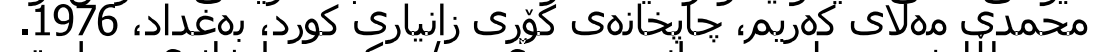

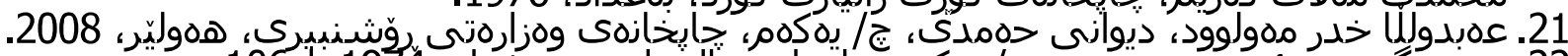

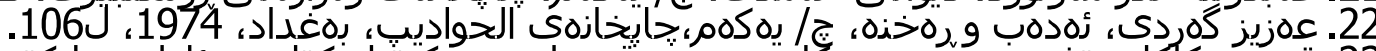

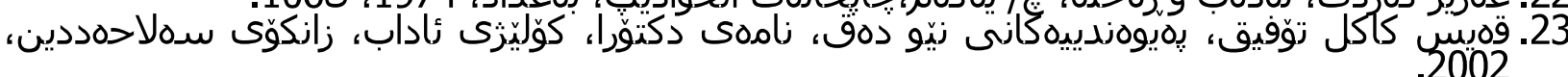

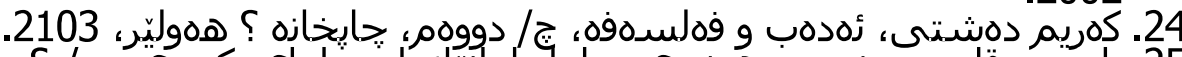

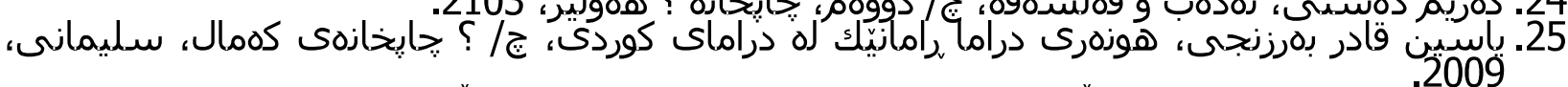

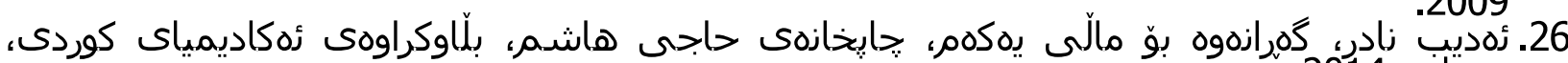
هذولِيْر، 2014. 


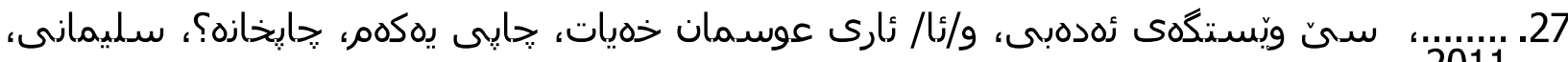
كُوّاركان

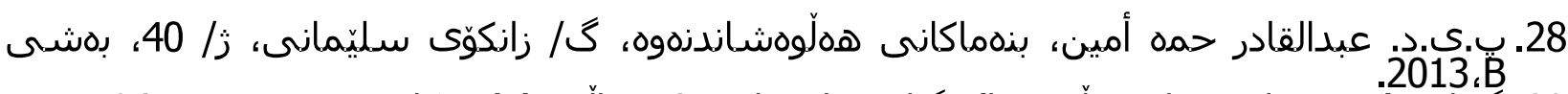

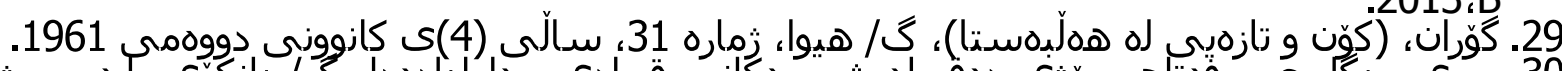

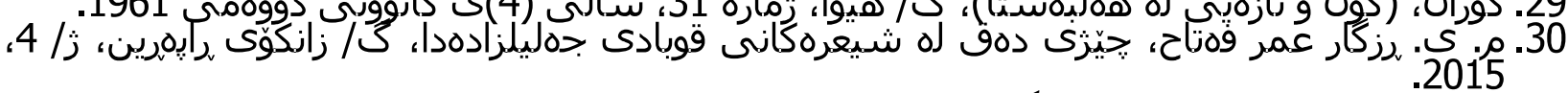

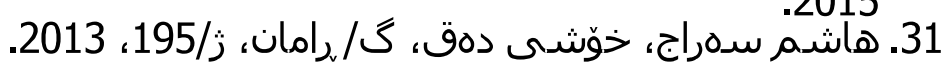

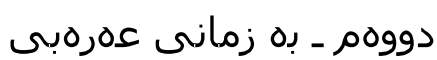

32. أحمد شايب، الاسلوب، طا السادسة، المطبعة ؟ ، القاهرة، 1966.

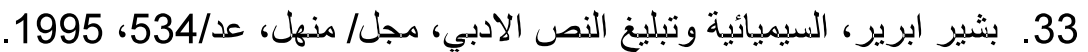

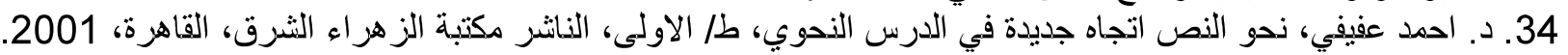

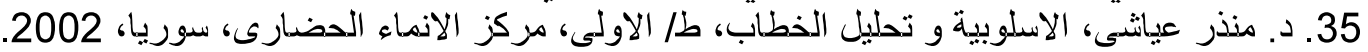

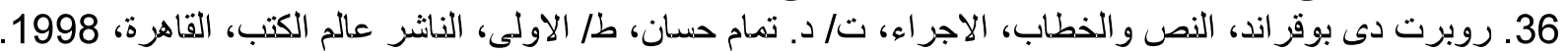

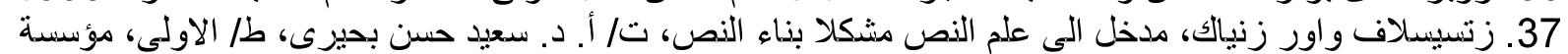

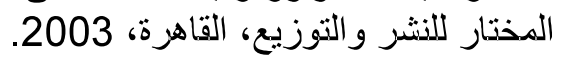

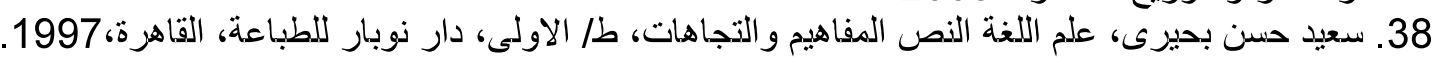

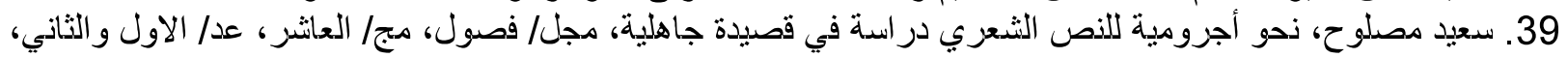

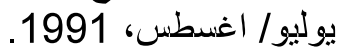

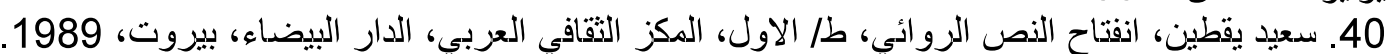

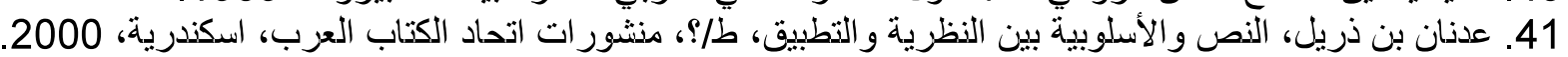

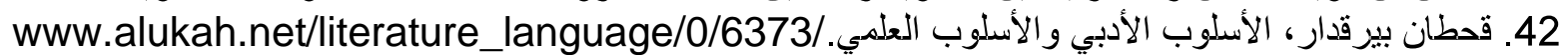

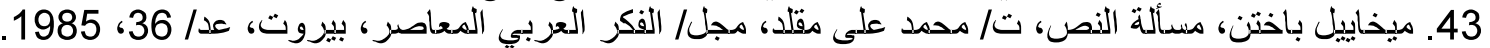

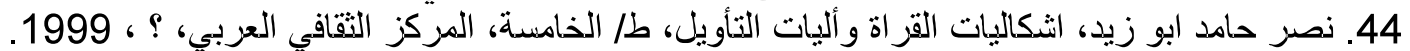

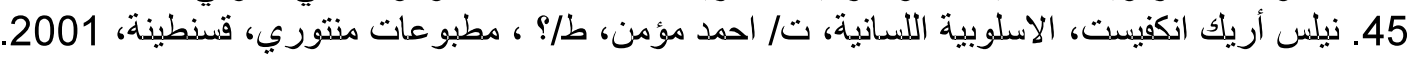

\section{References}

Abrir, Bashir, (1995). Semiotics and Literary Text Reporting, Menhal Journal, No. 534

Abu Zaid, Nasr Hamed, (1999). Problems of Reading and Means of Interpretation, Fifth / V, The Arab Cultural Center

Afifi,Ahmed (2001).Towards a New Text in the Grammar Lesson, first edition, Publisher AlZahraa Al-Sharq Library, Cairo

Alsabihi, Mohemmed Alakhzar, (2016). An introduction to the science of text and its practice areas, translated by Ibrahim Ahmad Shwan, first edition, cultural press, Erbil

Amin, Abdulqadir Hama, (2013). The Principles of Deconstruction, Journal of Sulaymaniya University, N.40, Part B

Ayashi, Munther, (2002). Stylistic and Speech Analysis, first edition, Center for Civilization, Syria 
Bahiri, Said Hassan, (1997). Linguistics Text Concepts and Directions, first edition, Dar Nubar Press, Cairo

Bakhtin, Mikhael, (1985). The Question of Text, Translated by Muhammad Ali Maqled, Journal of Contemporary Arab Thought, Beirut, No. 36

Barznji, Yasin Qadir, (2009). The Art of Drama, a view on Kurdish Drama, Kamal press, Sulaymaniyah,

Bayqdar, Qahtan, (2009). Literary Style and Scientific Method, www.alukah.net/literature_language/0/6373

Bayz,Halmat,(2013).Intertextuality in Bakhtyar Ali's The last Pomegranate of the World novel, first edition, Shahab press, Erbil

Chaib, Ahmed, (1966). Style, sixth edition, printing press, Cairo

Dashti, Karim, (2003). Literature and Philosophy, second edition, Erbil

de Bougrand, Robert,(1998).Text and disoure, Procedure, Translated by Tammam Hassan, first edition, Publisher World Books, Cairo

Divan of Haji Qadri Koyi, (1986). Research: Sardar Miran and Karim Mustafa Sharaza, Kurdistan cultural and general pres, Baghdad

Divan of Kurdi, (2011).Mohammed Mustafa Hama Bor, first edition, volume 1, Aras press, Erbil

Divan of Mahwi, (1984). Mala Abdulkarim Mudaris and Mohammed Mala Karim, second edition, Hisam press, Baghdad

Divan of Nali, (1976).Mala Abdulkarim Mudaris and Fatih Abdulkarim, Kurdish information council press, Baghdad

Divan of Salm, (1972). Second edition, Kurdistan press, Erbil

Dzaee, Abdulwahid Mushir,(2014). Pragmatics of Text and Discourse, first edition, Awer press, Erbil

Enkvist, Nils Arik (2001). Stylistic linguistics, Translated by Ahmed Mo'men, I /? , Montessori Publications, Constantine

Fatah,Rzgar Humar,(2015).The Pleasure of the Text in Qubadi Jalilzada's poetries, Journal of Raparin University, N. 4

Gardi, Aziz, (1974).Literature and Criticism, first edition, Hawadith Press, Baghdad

Goran, (1961). Old and Newness in Poetry, Hiwa Journal, N.31

Harf, Hama Karim, (2009). My Word, directorate of sulaymaniyah press, sulaymaniyah 
Hussein, Himdad, (2007). Literary Schools, first edition, Mukryani research agency, Aras press, Erbil

Kaki, Hamanuri Humar, (2008). Style in Kurdish Classic Poetry, first editon, Tishk Press, sulaymaniyah

Karim, Hama Sahid Hama, (1986). Kurdish Classic Poetry, ministry of culture, Baghdad

Khanzad, Ali Qadir, (2012).Poetic language of Mahwi, Haji Qadri Koyi and Sheikh Raza Talabani, first edition, Haji Hashm press, Erbil

Khaznadar, Marf (2010).History of Kurdish Literature, volume 3, second edition, Aras press, Erbil

Mauldwd, Abdullah Khdir, (2008).Divan of Hamdi, first edition, cultural ministry press, Erbil

Mohammed, Abdulqadir Hama Amin, (2008). Functional strueture in Modern Kurdish texts, first edition, Tishk press, Sulaymaniyah

Musallouh, Said, (1991).Towards Agromy of the Poetic Text Study in the Jahiliyya poem, Journal / chapters, volume 10, N 1 / 2, July / August

Nadr, Adib, (2014). A return to first home, Haji Hashm press, published by Kurdish academia, Erbil

Nadr, Adib, (2011). Three literary stages, translated by Ari Husman Khaiat, first edition, Sulaymaniyah

Qadir, Sherko Hama Amin, (2009).An Analysis of Short text discourse, Ranj Press, Sulaymaniyah

Qadir, Sherko Hama Amin, (2009). An Analysis of Short text discourse, Ranj Press,

Sulaymaniyah

Rasul, Shukrya, (1989). Kardish literature and Literary arts, Higher education press, Salahadin University

Sahid, Ahmad (2017). The voice of Mustafa Bagi Kurdi in Kurdish classic literature, Renma press, Sulaymaniyah

Saraj, Hashm (2013). The Pleasure of the Text, Raman Joural, N.195

Shwan, Ibrahim Ahmad, (2014). Comparative Literature, first edition, Salahadin University press, Erbil

Threil, Adnan Bin,(2000).Text and Stylistic Theory and Practice, Publications of the Arab Writers Union, Alexandria 
Tofiq, Qais Kakl, (2002). Textual relations, PhD thesis, college of literature, Salahadin University

Yokatin,Said,(1989).The Opening of the Novel Text, first edition, The Arab Cultural Center, Casablanca, Beirut

Zniak, Zetsislav Wawr, (2003). Introduction to Text Science, Building Text, Translated by A. Dr.. Saeed Hassan Bahiri, first edition, Al-Mukhtar Foundation for Publishing and Distribution, Cairo 